Coleção Micropolítica do Trabalho e o Cuidado em Saúde

\author{
Letícia de Moraes Falleiro
}

Organizadora

\title{
Experiências de Apoio Institucional no SUS: da teoria à prática
}

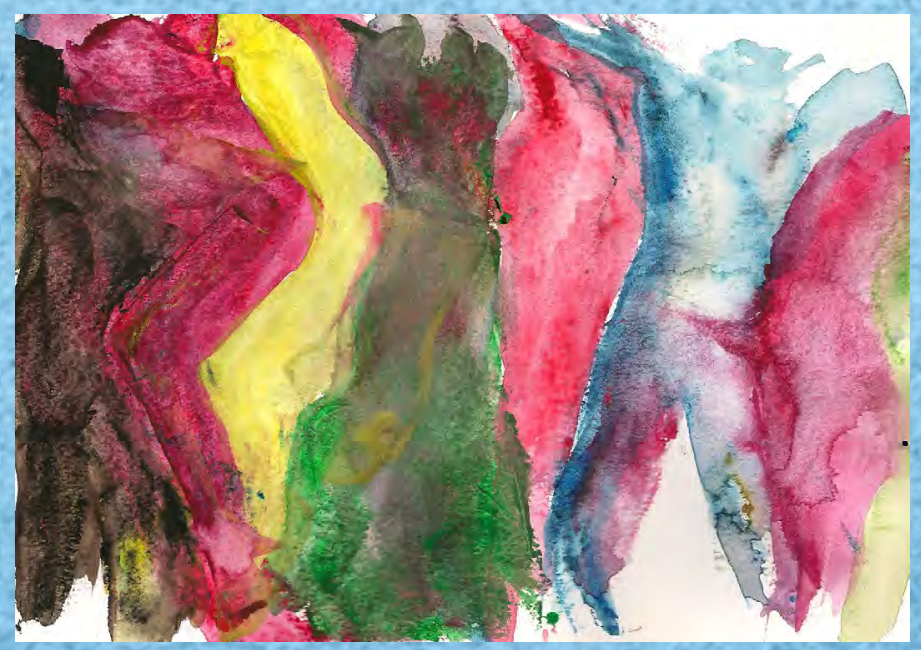

editora

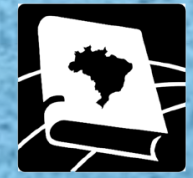

redeunida 
Letícia de Moraes Falleiro

Organizadora

\section{Experiências de Apoio Institucional no}

SUS: da teoria à prática 
Coordenador Nacional da Rede UNIDA

Alcindo Antônio Ferla

\section{Coordenação Editorial}

Alcindo Antônio Ferla

Conselho Editoria

Alcindo Antônio Ferla

Adriane Pires Batiston

Emerson Elias Merhy

Izabella Matos

Ivana Barreto

João Henrique Lara do Ama

João José Batista de Cam

Laura Camargo Macruz Feuerwerker

Lisiane Böer Possa

Liliana Santos

Mara Lisiane dos Santos

Márcia Regina Cardoso Torres

Marco Akerman

Maria Luiza Jaeger

Maria Rocineide Ferreira da Silva

Ricardo Burg Ceccim

Rossana Baduy

Sueli Barrios

Túlio Franco

Vanderléia Laodete Pulga

Vera Lucia Kadjaoglanian

Vera Rocha

\section{DADOS INTERNACIONAIS PARA CATALOGAÇÃO NA PUBLICAÇÃO (CIP)}

E96 Experiências de apoio institucional no SUS: da teoria à prática /

Letícia de Moraes Falleiro, organizadora. - 1. ed. Porto Alegre: Rede UNIDA, 2014

263 p. : il. - (Coleção Micropolítica do Trabalho e o Cuidado em Saúde)

ISBN 978-85-66659-30-6

1.Apoio institucional - Saúde. 2. Sistema Único de Saúde. 3. Bahia. 4. Gestão em saúde. 5.Apoiadores.I. Falleiro, Letícia de Moraes. II. Título. III. Série.

\section{CDU: 614.39}

NLM: WA525

Bibliotecária responsável: Jacira Gil Bernardes - CRB 10/463

Todos os direitos desta edição reservados à

ASSOCIAÇÃO BRASILEIRA REDE UNIDA

Rua São Manoel, no 498 - 90620-110 - Porto Alegre - RS

Fone: (51) 3391-1252

www.redeunida.org.br

\section{Agradecimentos}

Agradecemos o empenho de todos que participaram da elaboração deste livro:

Aos autores, pela paciência e persistência cotidiana, por debaterem conosco sobre Apoio Institucional, Apoio Matricial e Educação Permanente em Saúde, por nos apresentarem outros pontos de vista, por nos desafiarem quando defendíamos nossas verdades, por discordarem das nossas intervenções nos textos e também por aceitarem com humildade a lapidação tão precisa de cada parágrafo.

À Raimunda Maria Cerqueira Santos, por aceitar o convite para revisar todos os textos que compõe essa publicação e por cuidar com tanto empenho e zelo desta obra.

À Caroline Castanho Duarte, por aceitar o convite e por suas palavras tão carinhosas após a leitura de cada texto.

Ao Prof. Dr. Tulio Franco, pelo voto de confiança.

À editora Rede UNIDA, pela publicação deste material.

Celebramos os 11 textos publicados neste livro!

Celebramos a riqueza da troca de experiências! 
"Quem viu, viu Quem não viu quer vê

Quem virá verá Como é que faz tempo bom quando quer chegar Quem viu, viu Quem não viu quer vê Quem virá verá Se você quer ver tempo bom Comece a plantar"

(Trecho da música Festa na AldeiaAmadeu Alves e Seu Reginaldo) 


\section{Sumário}

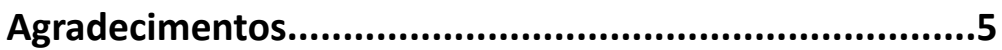

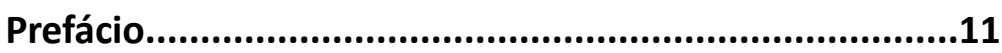

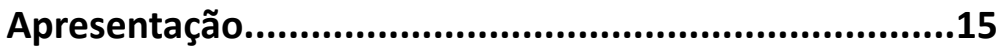

Considerações preliminares sobre Apoio Institucional e Educação Permanente.

Parte I - Implantação do Apoio Institucional.......31

De "Técnicos" a "Apoiadores": Experiência de Apoio Institucional na Rede Hospitalar e Especializada na Bahia...... .33

Processo de trabalho e diferentes modalidades de Apoio do NASF no Município do Oeste Baiano.

A Vivência de Apoio Institucional na 7ạ Diretoria Regional de Saúde.

Parte II - O Apoio Institucional no Território.

Apoio Institucional à Gestão Municipal de Saúde para implantação do Acolhimento. 91

Construção de Linha de Cuidado Materno-Infantil: relato de experiência em um município baiano .... 
Parte III - O processo de trabalho do Apoia-

dor. 149

O Apoio Institucional temperado com música......................................................................151

Os sentidos de uma experiência ao habitar o território no Apoio Institucional descentralizado. 161

Inserção e Acolhimento de trabalhadores numa equipe de Apoio Institucional da Diretoria de Atenção Básica. 185

O cotidiano do Apoio Institucional: o trabalho em equipe... 209

De Apoiadora à coordenadora: uma jornada de autoconhecimento e gestão de coletivos no Apoio Institucional vivenciada na Bahia. .231

Anexo.

Quem somos nós: organizadora, colaboradoras, revisora e autores.

\section{Prefácio}

Caro(a) leitor(a),

As estratégias de "Apoio" a equipes de trabalho têm sido cada vez mais experimentadas no Sistema Único de Saúde. A crescente produção teórica sobre Apoio Institucional e Matricial nos últimos anos tem nos demonstrado caminhos factíveis de como e onde investir energia na gestão das políticas públicas para a renovação das práticas de saúde. Estou certa de que este livro de experiências de Apoio Institucional e Matricial da Bahia vem a acrescentar nesse contexto, expressando um pouco da luta e do trabalho realizado cotidianamente para o fortalecimento do Sistema Único de Saúde (SUS).

Com linguagem simples e direta, o livro traz diversas experiências e acontecimentos que nos remetem ao que representa: tornar-se Apoiador(a) nas organizações de saúde; compor equipes e projetos de Apoio; e apoiargestores e trabalhadores no contexto do SUS. São 11 narrativas de experiências concretas. Os autores são trabalhadores/ gestores que trazem, na linguagem, a emoção de quem vive e repensa sua própria ação e existência no mundo. São registros de vida intensa no trabalho e acontecimentos que se passam há anos na Bahia.

Os relatos falam de métodos e de medos, de agendas 
e encontros, de projetos e desfechos. São experiências de Apoio Institucional e Matricial a diferentes equipes de trabalho que demonstram arranjos e práticas direcionadas a prefeitos, gestores, trabalhadores da saúde e aos próprios Apoiadores(as). A partir de diferentes contextos, abordam ações de sucesso e fracasso da prática. Também apontam fragilidades e celebram as fortalezas encontradas em cada caminhada.

O livro consegue dar voz aos Apoiadores(as), permitindo uma exposição de diferentes olhares, análises e perspectivas sobre as políticas de saúde. Com a leitura destes textos, é possível entrar em contato com o que realmente nos ocupa e preocupa nas práticas de Apoio Institucional, além de compreender o que sente o Apoiador(a) em seu universo de trabalho.

Minha trajetória como Apoiadora e coordenadora em equipes de Apoio Institucional na Bahia permitiu-me trabalhar com a maioria dos autores aqui reunidos e, muitas das experiências aqui descritas, pude acompanhar de perto. Eis porque esta obra me parece tão profunda - tomando de empréstimo as expressões das autoras - a simples leitura me levou a uma "jornada de autoconhecimento", "como se reviver a experiência através da escrita fosse algo maior do que vivê-la".

Na caminhada pelo Sistema Único de Saúde - SUS, entrei em contato com diversos coletivos e pessoas em projetos que envolvem arranjos de Apoio a equipes, e participei de muitas rodas de discussão e encontros que falavam sobre como apoiar no contexto da gestão do SUS e das políticas públicas. Com a fala do Apoiador(a), pude sentir o lugar do brilho e o lugar da dor de quem habita entre-lugares. Envolto em tantas expectativas, missões, ferramentas, tecnologias, o Apoiador(a) sempre deixa vazar nos espaços seus afetos, como nos textos aqui reunidos, dando visibilidade aos significados de sua prática.

De fato, Apoiadores(as) e equipes de Apoio Institucional formam-se e conformam-se mesmo em ato. Não há formula que dê conta de tamanha complexidade. A singularidade de cada contexto precisa ser preservada em cada arranjo de Apoio e tudo deve se adequar ao constante movimento. Por isso, a Educação Permanente é a dobra perfeita do Apoio. Por meio da análise das vivências, da troca de experiências, do compartilhamento de saberes, poderes e afetos, o Apoiador(a) se cria e cria condições de apoiar.

Percebo, neste livro, a potência de servir a muitos Apoiadores(as), gestores e equipes de saúde, como ferramenta para seus processos de Educação Permanente. Para mim, ele funcionou como um verdadeiro dispositivo de autoanálise, o que me possibilitou rever trajetórias, aprendizados e significados de minha prática pessoal.

Desejo que essa obra possa circular em muitas mãos como um autêntico livro coletivo, que seja muito útil às pessoas que trilham caminhos de fortalecimento de projetos coletivos. Tenho certeza que estes registros cartográficos irão contribuir muito para ampliar nossas condições de análise e formulações no campo das práticas de “Apoio"no SUS.

Boa leitura!

À equipe de autores(as), gratidão e amor.

Caroline Castanho Duarte

Mãe de Clarice.

Enfermeira envolvida com coletivos, gestão, Atenção Básica e política pública. 


\section{Apresentação}

A ideia de construir um livro de experiências do Apoio Institucional nasceu a partir da minha experiência como Apoiadora na Diretoria da Atenção Básica da Superintendência de Atenção Integral à Saúde da Secretaria da Saúde do Estado da Bahia (DAB/SAIS/SESAB).

Em 2007, a equipe gestora da DAB iniciou um processo de reestruturação e reorganização da diretoria. Desde então, seus trabalhadores vivenciam o Apoio Institucional e a Educação Permanente em Saúde como estratégias centrais da Política Estadual da Atenção Básica.

A partir do desenvolvimento do Apoio Institucional e Matricial aos gestores das Diretorias Regionais de Saúde (DIRES) e municípios pelos Apoiadores da DAB, essa estratégia foi se ampliando pelo Estado, sendo implantada também nos setores da Atenção Básica das DIRES e de alguns municípios. Da mesma forma, quando surgiu a FESF, a Função Apoio foi incorporada a essa instituição.

Quando entrei na DAB, em 2010, os Apoiadores já manifestavam o desejo e a preocupação de sistematizar, registrar e compartilhar as experiências de Apoio Institucional da $\mathrm{DAB}$, com o objetivo de contribuir para o avanço da gestão do SUS.

Então, em 2012, mobilizei um grupo de Apoiadores 
para tornarmos esse sonho realidade. Sabendo que há muitas histórias boas para contar, muitas experiências inovadoras sendo desenvolvidas, as quais, ao serem compartilhadas, ganham ainda mais valor ao contribuírem para o avanço da organização da gestão do SUS, optamos por um livro com relatos de experiências, escritos pelos próprios apoiadores. Essa decisão foi inspirada por uma obra de relatos de experiências de Educação Popular que, assim como o livro de "experiências do Apoio na Bahia", preocupou-se em dar voz às pessoas que desenvolvem essa estratégia no cotidiano, que vivenciam e superam seus desafios, que festejam o êxito, que aprendem com os equívocos, que reorientam suas práticas dia após dia em busca do melhor resultado, e que, muitas vezes, passam despercebidas em meio a tantos especialistas e acadêmicos.

O primeiro passo foi definir o desenho do livro: "Um livro de relatos de experiências de Apoio Institucional no Estado da Bahia". Seria um livro não institucional, contendo a produção cotidiana do Apoio Institucional, relatada pelos próprios apoiadores. Foram estabelecidos os critérios de inclusão dos textos e divulgado o convite para os Apoiadores, incluindo as pessoas que já tinham passado pelo Estado e vivido essa experiência.

O segundo passo foi a leitura, avaliação e seleção dos textos, até restarem as onze experiências contadas a seguir. Além disso, todos os textos selecionados passaram por um processo de lapidação intenso, criativo e bastante trabalhoso, para garantirmos a qualidade do material publicado. É importante que todos possam ler e compreender nossa linguagem, para que as experiências possam ser acessadas por todos que tiverem interesse, e não apenas pelos que vivenciam o mundo acadêmico.

O terceiro passo foi a revisão linguística dos textos, desempenhada de forma minuciosa e carinhosa por nossa revisora, garantindo a qualidade da apresentação dos mesmos.

Enfim, o quarto e último passo foi encontrar uma editora para publicação da obra. Nessa etapa, contamos com a sincronicidade da vida, e com a intuição de Rebeca Barros, a fim de encontrarmos novos parceiros, o que nos deixou muito felizes por podermos compartilhar estas histórias.

Desde o primeiro passo, passou-se um pouco mais de um ano e onze meses de trabalho intenso, criativo e coletivo, o qual começou com o sonho de dar voz e espaço para aqueles que cotidianamente vêm construindo novas formas de fazer gestão no SUS.

O desafio foi a nossa inspiração. Estamos desbravando um caminho desconhecido para nós, que é a organização e produção de um livro. Além disso, a responsabilidade e, também, a alegria pela publicação desta obra são imensuráveis, pois, assim como eu, todas as pessoas envolvidas na construção do livro (os colaboradores, a revisora e os autores) trabalham com o Apoio Institucional.

Para facilitar a leitura e identificação dos temas de seu interesse, dividimos o livro em três sessões:

Parte I - Formulando arranjos de Apoio - Esta sessão apresenta experiências de inovação em três diferentes contextos: gestão estadual de Rede Hospitalar; equipe de Núcleo de Apoio à Saúde da Família (NASF); e equipe de gestão de Diretoria Regional de Saúde (DIRES).

Parte II - Apoiando equipes no território - Esta sessão detalha três estratégias de apoio a municípios. São três textos com distintos objetos: implantação de Acolhimento na Saúde da Família; implantação de linha de cuidado na rede; e acolhimento de novos prefeitos e gestores de saúde pós-definição de cenário eleitoral. As experiências 
envolvem gestores e trabalhadores de saúde e acontecem com o Apoio da DAB/SAIS/SESAB.

Parte III - Vivendo o dia a dia do Apoiador - Esta sessão reúne quatro textos que contemplam reflexões e análises sobre o cotidiano do Apoiador. São três textos que tratam das impressões dos Apoiadores sobre seu processo de trabalho e um texto referente à experiência de coordenar uma equipe de Apoio Institucional.

Sei que há muitas experiências que não puderam fazer parte deste livro. Porém, também é gratificante encontrar aqui tantas experiências vivas, cheias de emoções, de entrega, de coragem, e poder apresentá-las agora, em primeira mão.

Não foi possível abordar, neste livro, toda a história da implantação do Apoio Institucional na Bahia, porque muitas pessoas que passaram pelo início desta experiência trabalham atualmente em outras instituições e não puderam enviar seus relatos. Por isso, optamos por manter o foco deste livro no desenvolvimento do Apoio. Também correríamos o risco de cometer injustiças ao deixar de citar uma ou outra pessoa, ou mesmo de simplificar ou resumir uma história tão complexa, vivida por tantas pessoas, e acabarmos relatando apenas um ponto de vista. Acredito, e desejo, que aqueles que iniciaram a implantação do Apoio na Bahia, em 2007 e nos anos seguintes, ficarão felizes ao se identificarem com as histórias aqui relatadas.

Finalmente, este livro não pretende oferecer um método, um passo a passo, ou funcionar como um manual. Pretende, sim, ser um dispositivo para a Educação Permanente de gestores e trabalhadores do SUS. Desejo que, após a leitura, cada relato sirva como uma contribuição, um olhar, uma ideia, e inspire coragem para novas práticas.

Desejo que sua leitura seja prazerosa e inspiradora!

\section{Considerações preliminares sobre Apoio Institucional e Educação Permanente}

\author{
Letícia de Moraes Falleiro, Rebeca Silva de Barros, Vanessa Carol de
} Souza Lima, Caroline Castanho Duarte

Um dos maiores desafios no Sistema Único de Saúde (SUS) tem sido inovar as práticas de gestão. A transformação dos modos tradicionais de gerir pessoas, processos de trabalho, recursos e políticas públicas de saúde tem sido foco de trabalho e estudo em diversos contextos do país. Dentre as iniciativas e inovações experimentadas, estão em destaque os arranjos de Apoio Institucional. Segundo o Dicionário Aurélio, a palavra apoiar tem como sinônimos dar apoio a, aprovar, amparar, defender, favorecer, sustentar, firmar, encostar, fundar, fundamentar, arrimar-se e prestar auxílio mútuo (FERREIRA, 2010).

Como "função" Apoio, no contexto organizacional, entende-se o papel exercido por agentes que trabalham e assumem posicionamento subjetivo, ético e político de acordo com uma metodologia de Apoio. Os objetivos dos arranjos de Apoio Institucional experimentados pelas organizações são, em geral, comprometidos com a transformação dos processos de trabalho e das relações exercidas entre os sujeitos. Costuma-se denominar "Apoio 
Institucional" as estratégias que se dão entre organizações, a exemplo da relação que acontece entre os entes federados do SUS - Município, Estado e União (OLIVEIRA, 2011, p. 46).

\section{Apoio Institucional para a qualificação da gestão em saúde}

Segundo Campos (2007), o Apoio é pensado como uma função gerencial que, a partir do princípio da cogestão, visa reformular o modo tradicional de fazer coordenação, planejamento, supervisão e avaliação em saúde.

A compreensão dada por Campos (2007) é a de que, na cogestão, são experimentadas formas de acolher as demandas provenientes dos diversos atores envolvidos no contexto, oferecendo diretrizes e submetendo tanto as demandas quanto as ofertas a processos de discussão, negociação e pactuação, construindo projetos de mudança do modo mais interativo possível.

A cogestão como base do Apoio Institucional pressupõe um modo de agir mais dialogado por parte da organização que intenta projetos de mudança. Busca-se construir relações e ações que valorizem o princípio da autonomia dos sujeitos e dos coletivos sobre suas próprias realidades e problemas. Assim, o Apoio Institucional procura enfrentar as práticas verticais e autoritárias, presentes nas relações intra e interinstitucionais, para superar os modelos de supervisão centrados na realização e fiscalização de normas e padrões que, em geral, são previamente estabelecidos por pequena parte da organização (BARROS et al., 2012).

Por meio do movimento constante de aproximação e diálogo entre gestores, trabalhadores das equipes de saúde e usuários, o Apoio Institucional configura-se como um arranjo que possibilita melhor organização das práticas e maior apropriação dos trabalhadores em relação ao seu fazer cotidiano. Com a finalidade de fortalecer os sujeitos e os coletivos implicados na construção de processos de cogestão e democratização das relações de poder, os arranjos de Apoio contribuem na perspectiva de transformar os modelos de gestão hierarquizados em modelos mais horizontalizados. Esses resultados sustentam-se em processos de Educação Permanente (BERTUSSI, 2010).

De acordo com Campos (2007), para que se realize a "função" de Apoio, são necessários, ao Apoiador Institucional, alguns recursos metodológicos, dentre os quais: (a) capacidade de construir rodas, ou seja, todo Apoiador Institucional é um ativador de espaços coletivos visando a interação intersujeitos na análise de situações e na tomada de decisão; (b) habilidade em incluir as relações de poder, de afeto e a circulação de conhecimentos em análise; (c) capacidade de pensar e fazer junto com as pessoas e não em lugar delas, estimulando a capacidade crítica dos sujeitos; (d) habilidade de apoiar o grupo para construir objetos de investimento e compor compromissos e contratos; (e) capacidade de trabalhar com uma metodologia dialética que, ao mesmo tempo em que traga ofertas externas, valorize as demandas do grupo apoiado, pois a metodologia dialética entende o homem como um ser ativo e de relações.

Isso significa que as ofertas que o Apoiador apresenta precisam ser trabalhadas, refletidas, reelaboradas, sempre coletivamente, para se constituírem em conhecimento e reformulação de suas próprias práticas.

Com base em Bertussi (2010), é possível identificar ferramentas necessárias à "função" de forma que o 


\section{Apoiador se torne:}

a) Articulador: produzindo conexão, considerando as singularidades de cada qual e a diversidade e mobilidade dos possíveis encontros entre sujeitos;

b)Educador: agindo pedagogicamente, tomando o mundo do trabalho como matéria prima para o aprendizado;

c) Escutador/Observador: agindo a partir da observação do cotidiano, dos movimentos da equipe e seu contexto, sempre aberto à escuta;

d) Facilitador: facilitando processos que contribuam para colocar as potências dos sujeitos e dos coletivos em evidência;

e) Negociador: mediando e buscando compatibilizar os interesses distintos envolvidos na formulação dos acordos e projetos comuns.

Um trabalhador que inicie sua jornada como Apoiador Institucional poderá tomar essas ferramentas como orientadoras do seu fazer. Para tanto, é importante que manifeste seu desejo de aprimoramento profissional e informe sua demanda Educação Permanente, assim como, é fundamental que a Instituição/Órgão capte essa demanda e invista na formação de sua equipe.

\section{O papel da Educação Permanente no desenvolvimento do Apoio Institucional}

Cada organização vive seus cenários políticos, onde atores sociais específicos, com ações, interesses e poderes distintos, compõem seu próprio jogo social ${ }^{1}$. Por isso, e

${ }^{1}$ Segundo a formulação teórica de Carlus Matus (apud COSTA, 2008), Ator por suas características inovadoras, os arranjos de Apoio Institucional desenvolvem-se de forma muito singular em cada organização. Nesse contexto, a Educação Permanente apresenta-se como a principal ferramenta do Apoiador, tanto para promover ampliação da capacidade de reflexão e de análise dos coletivos, quanto para tornar possível a sua própria formação no cotidiano do seu processo de trabalho.

Sentir a necessidade de mudança é uma condição indispensável para que um gestor ou trabalhador da saúde mude ou incorpore novos conceitos e ferramentas à sua prática. Essa necessidade não pode ser imposta e deve ser proveniente de um profundo questionamento sobre a suficiência de sua maneira de fazer ou pensar seu processo de trabalho no enfrentamento dos desafios cotidianos.

Considerando as características apresentadas sobre o desenvolvimento do Apoio Institucional como modo de inovar a gestão do SUS, identifica-se a Educação Permanente como a principal estratégia utilizada pelos Apoiadores para estimular mudanças de práticas na gestão e no cuidado em saúde. A Educação Permanente em Saúde, segundo Ceccim (2005, p. 976), "constitui estratégia fundamental às transformações do trabalho no setor para que venha a ser lugar de atuação crítica, reflexiva, propositiva, compromissada e tecnicamente competente".

Educação Permanente em Saúde é, portanto, um

Social é uma pessoa, grupo ou organização que participa de algum jogo social. O Ator Social possui um projeto político, controla algum recurso relevante, acumula (ou desacumula) forças e possui capacidade de produzir fatos capazes de viabilizar seu projeto. Todo ator social é capaz de fazer pressão para alcançar seus objetivos. É possível caracterizar o agir social como um jogo que pode ser de natureza cooperativa ou conflitiva. Num jogo social, diferentes jogadores têm perspectivas que podem ser comuns ou divergentes e controlam recursos que estão distribuídos entre os jogadores segundo suas histórias de acumulação de forças em jogos anteriores. Um conjunto de jogos sociais conforma um contexto que pode ser entendido como um sistema social. 
conceito estratégico para qualificação da gestão e da assistência, pois toma como matéria prima as práticas reais de profissionais reais em ação na rede de serviços.

Processos de Educação Permanente baseiam-se em metodologias ativas de ensino, como a aprendizagem significativa e a problematização. Nesse sentido, o aprender e o ensinar incorporam-se no cotidiano das organizações e do trabalho tendo como referência as necessidades das pessoas (sejam trabalhadores, gestores ou usuários), colocando-as como protagonistas dos processos de mudanças em suas realidades.

Conforme Ceccim e Ferla (2009), na Educação Permanente, existe a troca e o intercâmbio, o "estranhamento" e a "desacomodação" com os saberes e as práticas que estejam vigentes em cada lugar. Diante disso, o Apoiador, ao lançar mão dessa estratégia para ativar coletivos em processos de mudança, deve considerar que todos (inclusive ele) são, ao mesmo tempo, educandos e educadores; apoiadores e apoiados.

O Apoio Institucional, alicerçado no pressuposto da Educação Permanente, promove a pró-atividade dos trabalhadores, estimula a sua criatividade e propicia um campo fértil de produção de conhecimento em suas vivências marcadas por fracassos, sucessos, dificuldades e aprendizados. Atualmente, carecemos de mais textos que tratem do Apoio na prática: como fazer Apoio no dia a dia das organizações; como lidar com os desafios quando se propõe a mudar radicalmente o modo de fazer gestão; por que estratégias de Apoio são vistas como bem sucedidas ou mal sucedidas; como catalizar os aprendizados e as habilidades adquiridas individual e coletivamente pelos Apoiadores; quais analisadores possibilitam perceber resultados da ação de Apoio.

Em cada história contada neste livro, podemos identificar a influência da Educação Permanente no trabalho dos Apoiadores das diferentes organizações. As narrativas apresentadas nesta publicação revelam como a Educação Permanente em Saúde pode nutrir as práticas dos Apoiadores ampliando sua autonomia e desenvolvendo sua criatividade, na superação dos desafios.

O processo de implantação do Apoio Institucional na Bahia

O Apoio Institucional vem se desenvolvendo de inúmeras formas na gestão do SUS, seja no nível municipal, estadual ou federal, como opção contra-hegemônica em relação aos modelos de gestão mais tradicionais, marcados por certa burocratização, autoritarismo e tomada de decisão de forma verticalizada.

Algumas destas experiências foram implantadas pela Secretaria Municipal de Saúde (SMS) do município de João Pessoa (BERTUSSI, 2010), de Campinas (DOMITTI, 2006); pelo Conselho de Secretários Municipais de Saúde nos Estados do Rio de Janeiro, Alagoas, Minas Gerais (COSEMSRJ, 2013); pela Fundação Estatal Saúde da Família (FESFSUS); pelo Departamento de Atenção Básica da Secretária de Atenção à Saúde do Ministério da Saúde (DAB/SAS/MS).

Até 2007, a realidade encontrada na Atenção Básica da Bahia era de baixa resolutividade atrelada à inexistência de planejamento, avaliação e monitoramento; gestão centralizada e fragmentada; dificuldade de expansão, sem levar em consideração critérios de equidade; modelo da Estratégia Saúde da Família que não atendia à necessidade dos municípios baianos; falta de diálogo entre os níveis de atenção; falta de interesse político em desenvolver e 
estruturar a Atenção Básica, entre outras, ou seja, Atenção Básica não era prioridade.

A partir de 2007, iniciou-se o processo de implantação do Apoio Institucional na DAB/SAIS/SESAB, como um dos eixos estruturantes da Política Estadual de Atenção Básica (BAHIA. SECRETARIA DE SAÚDE DO ESTADO DA BAHIA, 2013), de acordo com a proposta do novo governo do Estado da Bahia, a qual apontava a necessidade de estabelecer uma gestão solidária com os princípios da ética, da participação e diálogo social, efetividade, transversalidade e regionalização (CUNHA; NASCIMENTO, 2009).

Essa estratégia organizacional propunha um novo modo de agir que buscava mais horizontalidade na relação entre Estado e Município e nos encontros entre gestores, trabalhadores e usuários. Costa (2009), em seu quadro comparativo entre os modelos de atenção da DAB/SAIS/ SESAB, resume a proposta implementada em 2007, com destaque para a constituição de uma gestão mais integrada; a qualificação da relação entre o nível estadual e municipal com vistas à descentralização solidária e pactuada; o investimento na transparência e democratização institucional, evitando a tomada de decisão de forma concentrada.

A opção dessa diretoria (DAB) por essa nova estratégia organizacional tomou como referencial teórico o Método Paidéia proposto por Campos (2007, p. 86).

O Apoio parte do pressuposto de que as funções de gestão se exercem entre sujeitos, ainda que com distintos graus de saber e de poder.

Por outro lado, assume que todo trabalho tem uma tríplice finalidade e produz efeitos em três sentidos distintos: primeiro, objetiva e interfere com a produção de bens ou serviços para pessoas externas à organização trabalha-se para um outro por referência à equipe de operadores -; segundo, procura sempre assegurar a reprodução ampliada da própria organização; e, terceiro, acaba interferindo com a produção social e subjetiva dos próprios trabalhadores e dos usuários. (...)

$\mathrm{Na}$ realidade, ao não reconhecer que toda gestão é produto de uma interação entre pessoas, verifica-se, com frequência, tendência a se reproduzirem formas burocratizadas de trabalho, com empobrecimento subjetivo e social dos trabalhadores e dos usuários. O Apoio Paidéia procura compatibilizar essas três finalidades, reconhecendo que a gestão produz efeitos sobre o modo de ser e proceder de trabalhadores e de usuários das organizações.

Dessa forma, a diretoria passou a buscar a ampliação da capacidade de reflexão, análise e de cogestão dos sujeitos; resgatar a noção de que todo o serviço de saúde, produzido pela gestão e/ou assistência deve ter uma utilidade para o usuário (valor de uso); reafirmar que os sistemas de saúde podem contribuir para a formação de sujeitos mais implicados com a implementação do SUS.

No Estado da Bahia, que adotou como um dos pilares de sua política de saúde a gestão solidária o fortalecimento da Atenção Básica, estrategicamente, passou-se a incentivar as Diretorias Regionais de Saúde (DIRES), de forma que os técnicos de referência da Atenção Básica também trabalhassem na lógica do Apoio Institucional em parceria com as equipes de Apoio Institucional da DAB/SAIS/SESAB. Dessa forma, esse modelo foi se capilarizando pelo território. Nesse sentido, a incorporação do Apoio Institucional tem se 
concretizado também como uma nova forma de organizar gestões municipais, assim como a Fundação Estatal de Saúde da Família (FESF-SUS) que, desde sua origem, adotou como estratégia central em sua prestação de serviços a conformação de sua própria equipe e metodologia de Apoio Institucional. As experiências propiciadas por essa nova forma de operar e produzir mudanças nas organizações na área da saúde têm possibilitado um novo discurso, uma outra forma de se fazer gestão.

As experiências apresentadas nesta publicação demonstram que a função Apoio na Bahia tem contribuído para ativar sujeitos e coletivos, agenciar encontros e instrumentalizar trabalhadores com ferramentas e conhecimentos. Os arranjos de Apoio favorecem a desconcentração do poder nas organizações e empoderam os sujeitos na busca de soluções para problemas locais. À medida que valoriza a autonomia e ativa o protagonismo dos sujeitos e coletivos nos diversos territórios baianos, os apoiadores trabalham fortalecendo as diretrizes de regionalização e descentralização da saúde e do SUS.

\section{Referências}

BAHIA. Secretaria de Saúde do Estado da Bahia. Diretoria de Atenção Básica. Política Estadual de Atenção Básica. 2013. Salvador: Secretaria da Saúde, 2013.

BARROS, R. S. et al. Gestão participativa e controle social. O Apoio Institucional como estratégia de gestão participativa. In: MOYSÉS, Samuel Jorge; GOES, Paulo Sávio A. de (Org.). Planejamento, gestão e avaliação em saúde bucal. São Paulo: Artes Médicas, 2012.
BERTUSSI, D. C. O apoio matricial rizomático e a produção de coletivos na gestão municipal em saúde. Rio de Janeiro: UFRJ. Faculdade de Medicina, 2010. Disponível em: <http:// www.ims.uerj.br/ccaps/wp-content/uploads/2012/07/ Bertussi_Tese.pdf $>$. Acesso em: 27 abr. 2013.

CAMPOS, G. W. S. Saúde Paidéia. São Paulo: Hucitec, 2007.

CECCIM, R. B. Educação Permanente em Saúde: descentralização e disseminação de capacidade pedagógica na saúde. Ciência \& Saúde Coletiva, 10 out./dez. 2005. Disponível em: <http://www.redalyc.org/articulo. oa?id=63010420 >. Acesso em: 05 jul. 2014.

CECCIM, R. B.; FERLA, A. A. Educação Permanente em Saúde. In: DICIONÁRIO da Educação Profissional em Saúde. Rio de Janeiro: Fundação Oswaldo Cruz. Escola Politécnica de Saúde Joaquim Venâncio, 2009. Disponível em: <http:// www.epsjv.fiocruz.br /dicionario /verbetes w/edupersau. html>. Acesso em: 6 jul. 2014.

COSEMS/RJ. Apoiadores Regionais: uma experiência brasileira. Rio de Janeiro: CEPESC: IMS/ UERJ: COSEMS/ RJ: OPAS, 2013. Organizado por: Roseni Pinheiro et al.

COSTA, G. Metodologia de diagnóstico de situações. In: COSTA, G; DAGNINO, R. (Org.). Gestão Estratégica em Políticas Públicas. Campinas: T+8, 2008.

COSTA, R. M. O. O processo de trabalho da equipe de Apoio Institucional com foco na gestão do trabalho e da educação na Atenção Básica no Estado da Bahia. Rio de Janeiro: FIOCRUZ, 2009. 122 f. Dissertação (Mestrado Profissional em Saúde Pública com Área de Concentração em Gestão do Trabalho e da Educação na Saúde) - Escola Nacional de Saúde Pública Professor Sérgio Arouca - ENSP/FIOCRUZ, Rio de Janeiro, 2009. Disponível em: <http://www.arca. fiocruz. $\mathrm{br} /$ bitstream/icict/2293/1/ENSP_Disserta\% C3\%A7\%C3\% A3o_Costa_Renata_Maria_Oliveira.pdf $>$. Acesso em: 27 
abr. 2014.

CUNHA. M. A. E.; NASCIMENTO, M. A. M. Percepção dos trabalhadores sobre a construção de uma gestão participativa na Diretoria da Atenção Básica da Secretaria da Saúde da Bahia. Salvador: UFBa, 2009. Trabalho de Conclusão de Curso apresentado à Escola Estadual de Saúde Pública da Bahia / Universidade Federal da Bahia - Escola de Enfermagem, 2009.

DOMITTI, A. C. P. Um possível diálogo com a teoria a partir das práticas de apoio especializado matricial na Atenção Básica de saúde. Campinas, 2006. 87 f. Tese (Doutorado Pós-Graduação em Saúde Coletiva) - Faculdade de Ciências Médicas da Universidade Estadual de Campinas, 2006. Disponível em: <http://www.sgc.goias.gov.br /upload/ links/ arq_ 888_ possiveldialogocomateoria.pdf $>$. Acesso em: 27 abr. 2014.

FERREIRA, A. B. H. Dicionário Aurélio da Língua Portuguesa. 5 ed. Curitiba: Positivo, 2010. 2272 p.

OLIVEIRA, G. N. Devir apoiador: uma cartografia da função apoio. Campinas: 2011. 175 f. Tese (Doutorado Pós-Graduação em Saúde Coletiva) - Faculdade de Ciências Médicas da Universidade Estadual de Campinas, Campinas, 2011. 


\section{De "Técnicos" a "Apoiadores": Experiência de Apoio Institucional na Rede Hospitalar e Especializada na Bahia}

Leandro Dominguez Barretto, João André Santos de Oliveira, Ana Cristina Guimarães, Yara Lúcia Pedreira

No decorrer do período entre o segundo semestre do ano de 2007 e o fim de 2009, cada um de nós viveu e foi marcado de diferentes formas pela experiência de construção e funcionamento do Apoio Institucional às Unidades da Rede Própria da Secretaria da Saúde do Estado da Bahia (SESAB), que se encontravam sob a Gestão Direta do Estado, ou seja, não terceirizadas. Nós, autores deste texto, fizemos parte da equipe da Diretoria da Rede Própria sob Gestão Direta (DIRPGD) que é uma das diretorias de apoio da Diretoria de Gestão da Rede Própria (DGRP), ligada hierarquicamente à Superintendência de Atenção Integral à Saúde da SESAB. Por razões que nos levaram para outros caminhos, não tivemos a oportunidade de continuar este projeto juntos a partir de 2009, mas o conhecimento e o saber da experiência ${ }^{1}$ vivida seguem juntos com cada um

\footnotetext{
“ “(..) o sujeito da experiência seria algo como um território de passagem, algo como uma superfície sensível que aquilo que acontece afeta de algum modo, produz alguns afetos, inscreve algumas marcas,
} 
dos que participaram ou continuam atuando nesta equipe.

O relato do trabalho desenvolvido neste período, proporcionado por este livro sobre Apoio Institucional, é uma oportunidade de resgatar esta experiência singular na área da Atenção Especializada no Estado da Bahia, como forma de socialização e registro de um processo que pode contribuir com ações futuras. Ao mesmo tempo, é também uma oportunidade de resgatar lembranças e vivências que muito mobilizaram desejos e sentimentos às vezes contraditórios, que povoaram os participantes desta equipe e a nós autores especificamente, colocando-nos mais uma vez em análise (e autoanálise) sobre o processo de construção e das escolhas feitas. Foram momentos de muito trabalho e desafios aparentemente insuperáveis, mas também de relações de cumplicidade em torno de um projeto de mudança da saúde da Bahia, centrado na inclusão, nos processos de negociação e pactuação em espaços coletivos e na busca da produção da autonomia dos sujeitos envolvidos.

Tentamos colocar aqui nossas implicações, sentimentos, dificuldades e satisfações, e ao mesmo tempo queremos permitir ao leitor compreender o contexto onde estávamos inseridos, para que possa servir, de alguma forma, como apoio à reflexão de situações em contextos semelhantes. Por isso, tentamos trazer um pouco da estrutura de funcionamento e seus processos, buscando fugir de uma descrição fria e estruturalista.

deixa alguns vestígios, alguns efeitos." (BONDÍA, 2002, p.24)

\section{Contexto Geral}

Àépoca desta experiência, a RedePrópria doEstado sob Gestão Direta era composta por um conjunto heterogêneo de Unidades de Saúde, sendo trinta e nove ao total, com vinte e oito hospitais de diversos portes e características, sete Unidades Ambulatoriais Especializadas (os Centros de Referência) e quatro Pronto-Atendimentos. Onze unidades eram localizadas em municípios do interior do Estado e as demais se localizavam em Salvador, consequências de uma municipalização tardia e ainda não plenamente concluída. A característica heterogênica deste grupo de Unidades era destacada não somente pela diferente natureza das mesmas (hospitais, centros de referência, pronto atendimento), mas também pela variada tipologia das unidades hospitalares, pois entre os vinte e oito hospitais estavam incluídos tanto os maiores e mais complexos hospitais do Estado, como também hospitais de pequeno porte do interior, que funcionavam como importantes referências para algumas regiões.

Uma equipe multiprofissional de técnicos (enfermeiro, assistente social, nutricionista, fisioterapeuta, odontólogo, administrador, médico, economista) era responsável pelo acompanhamento dessas Unidades, mantendo comunicação à distância ou em visitas eventuais, bem como por meio de pareceres técnicos em processos de solicitações de recursos e projetos oriundos das Unidades de Saúde.

A partir do fim do ano de 2007, assumimos a direção desta equipe de técnicos da Rede Própria com a tarefa de desenvolver ações estratégicas para a nova gestão da saúde no Estado, compatível com os compromissos de fortalecimento do Sistema Único de Saúde, assumidos pelo novo Governo iniciado naquele ano. Dentre as ações 
estratégicas na área de atenção hospitalar e especializada junto com Rede Própria estavam: a qualificação e modernização da estrutura física das Unidades; a ampliação de leitos e do acesso aos serviços; o desenvolvimento da Gestão da Informação juntos às Unidades; a qualificação da Gestão de Pessoal nas Unidades; a municipalização de Hospitais de Pequeno Porte; a articulação das Unidades com a Rede de Serviços locorregionais; a organização de Linhas de Cuidado prioritárias para atenção especializada desenvolvida pelos hospitais da Rede Própria; a mudança do modelo de gestão de hospitais estratégicos.

A situação de muitas Unidades era precária, por isso sempre que abríamos espaço para escuta de demandas recebíamos uma "enxurrada" de pedidos. Vale lembrar que a Rede Própria não controlava a execução de muitas ações como compras de equipamentos, obras, investimentos, contratação de pessoal, sendo necessária uma interlocução com os diversos setores da SESAB para viabilizar as necessidades pactuadas com as Unidades. Na maioria das vezes não havia recurso suficiente para atender todos os pedidos. Além disso, vivíamos a pressão da sobrecarga dos grandes Hospitais de Urgência, com falta de leitos para pacientes graves e uma relação tensa no processo de regulação destes leitos, conformando-se em uma pauta que ocupava muito e de forma não planejada a agenda da equipe de direção. Essa situação foi produtora de muita angústia durante algum tempo, com atravessamento de agendas, desestruturação de pautas e a convivência com a morte de pessoas nos hospitais e unidades de saúde que acompanhávamos.

Por fim, havia uma grande expectativa quanto a repostas da Rede Própria, que concentra a maior quantidade de trabalhadores da SESAB e os grandes problemas assistenciais da Rede Hospitalar. Sentíamos esta expectativa no cotidiano, com muitas agendas de diversos setores da SESAB e outras Secretarias pautando a Rede Própria, gerando uma tensão que precisávamos abordar em nossas conversas quase diariamente.

\section{O processo de trabalho da equipe}

À medida que assumíamos o cotidiano da Direção da equipe, fomos conhecendo o processo de trabalho instituído no local. Percebemos que a equipe trabalhava "sob demanda", tanto dos hospitais como dos demais setores do Nível Central. Dos hospitais vinham as demandas de liberação de processos ou pedidos de autorização de recursos voltados principalmente para obras, equipamentos e pessoal. Dos setores da SESAB provinham demandas de pareceres e levantamento de necessidades para investimento, bem como levantamentos de informações para agendas estratégicas como atualização de cadastros, indicadores assistenciais, etc. Para atender às demandas apresentadas e a formalização de pareceres, a equipe de técnicos baseava-se em protocolos e normas instituídas pela própria SESAB e/ ou outras instituições subsidiando os mesmos. O projeto político-sanitário para cada Unidade nem sempre estava claro ou disponível para estes atores.

A interação com as equipes de gestão das Unidades era definida a partir de demandas para diagnósticos, aplicação de questionários, inspeções ou para subsidiar pareceres dos diversos processos que chegavam diariamente à Diretoria. $O$ grupo de técnicos com frequência referia a falta de governabilidade em muitas ações, pois nem sempre o que era identificado como necessidade era efetivamente priorizado. Havia um sentimento de desempenhar um 
papel de "apontador" da existência de não conformidades, que nem sempre podiam ser efetivamente abordadas. Este era um desconforto muito presente, que nos afetou ao iniciarmos o trabalho na Diretoria, nos mobilizando para pensar alternativas de construção de uma relativa governabilidade e consequente envolvimento maior do técnico nas decisões e com o próprio objeto de trabalho junto às Unidades.

Apesar da realização de uma certa escuta qualificada (MERHY et al., 1997) nas visitas, ficava a mesma em segundo plano, em virtude das tarefas que deveriam ser cumpridas. Utilizando o conceito de Composição Técnica do Trabalho, oferecido por MERHY e FRANCO (2003), podemos dizer que o trabalho vivo desenvolvido pela equipe de técnicos era governado pelo trabalho morto ${ }^{2}$ realizado no momento em que a demanda foi construída sem a participação do técnico, anterior à visita com predomínio do uso de tecnologias leve-duras e duras ${ }^{3}$ que permitiam pouca margem para situações que fugissem à tarefa previamente solicitada. 0 trabalho morto (aquele já realizado e acabado) poderia ser representado pela emissão de um parecer arquivado em

\footnotetext{
2 Trabalho Vivo representa o trabalho no momento em que o mesmo acontece, sendo o único momento em se pode operar com Tecnologias Leves. Já o Trabalho Morto representa o produto de um trabalho humano já acabado, resultado do trabalho vivo anterior que o produziu, caracterizado por tecnologias duras e leve-duras. O Trabalho Vivo também opera com tecnologias duras e leve-duras, mas a disputa está justamente sobre o que preside esta ação, se as tecnologias leves e o momento vivo em ato, ou se o trabalho morto realizado anteriormente. (MERHY, 2002).

3 "[...] as tecnologias envolvidas no trabalho em saúde podem ser classificadas como: leves (como no caso das tecnologias de relações do tipo produção de vínculo, autonomização, acolhimento, gestão como uma forma de governar processos de trabalho), leve-duras (como no caso de saberes bem estruturados que operam no processo de trabalho em saúde, como a clínica médica, a clínica psicanalítica, a epidemiologia, o taylorismo, o fayolismo) e duras (como no caso de equipamentos tecnológicos do tipo máquinas, normas, estruturas organizacionais)." (MERHY, 2002, p. 49)
}

um processo (pasta), sendo este o produto do trabalho do técnico. O momento vivo de interação com as equipes de gestão das Unidades e entre os técnicos em si, território de tecnologias leves (escuta, acolhimento, vínculo), com a possibilidade de construção de novos significados e pactuação de projetos, poderia até mesmo atrasar o produto esperado, por isso não eram valorizados numa rotina onde as ações seguem um padrão independente da singularidade do acontecimento, predominando a repetição e a cristalização de determinadas ações.

Por fim, havia uma expectativa que a equipe de técnicos também realizasse uma espécie de supervisão das Unidades com o monitoramento de informações (como produção de serviços) e andamento de outras atividades, sendo realizada geralmente com a aplicação de questionários específicos. Em geral, também o retorno às Unidades de Saúde a respeito do resultado de avaliações era feito na forma de relatórios impressos, sem uma discussão sobre seus resultados.

\section{Incômodos}

Compatível com nossa trajetória, tanto no cuidado como na gestão, trouxemos como tema principal de análise o cuidado em saúde que era produzido pelas Unidades da Rede Própria com as muitas complexidades que elas possuíam. Não era suficiente garantir o funcionamento de processos estruturados que viabilizassem o suprimento de insumos e atendimento às demandas dos serviços. Era necessário articular o papel de cada Unidade na rede de serviços (cuidado produzido em Rede), mas principalmente o cuidado articulado entre os diversos profissionais e setores, 
tendo como implicação a constituição de serviços que orientam suas ações para o atendimento às necessidades de saúde dos usuários e a produção de autonomia, compatível com processos de gestão mais participativos e colegiados. No entanto, ao nos depararmos com o contexto descrito, ficamos profundamente afetados por múltiplas questões. Como desenvolver o trabalho que desejávamos, em um contexto de tantas demandas urgentes e difusas? Como envolver a equipe de técnicos que não se sentia empoderada no cotidiano do seu trabalho? Como produzir um processo de mudança para uma gestão participativa, colegiada e centrada nas necessidades de saúde dos usuários, em Unidades de Saúde complexas e com tantas demandas estruturais?

Outro aspecto relevante é que trabalhar na área hospitalar especializada exige um conhecimento específico sobre a gestão destes espaços, sobre os mecanismos de produção do cuidado em unidades especializadas e das lógicas que operam no mercado, nas profissões e especialidades que atuam nestes serviços. Este saber não era comum à maioria dos membros da equipe, nem aos que já estavam, nem aos novos. Havia a necessidade de saber mais sobre o objeto "hospital - serviços especializados" para enfrentar alguns destes desafios.

Como enfrentar os desafios colocados para esta Diretoria neste contexto? Era preciso investir na formação inicial da equipe em um curto espaço de tempo (mesmo compreendendo que estamos sempre em formação), mas sem prejudicar o andamento das ações, considerando também a tensão produzida pela necessidade de resultados no pouco tempo disponível.

Dessa forma, havia a necessidade de equilibrar o desejo que nos mobilizava para provocar determinadas mudanças no processo de trabalho das Unidades de
Saúde, com a demanda real e necessária de dar respostas a demandas estruturadas, do contrário, não seria possível sustentar um projeto de mudança frente ao pragmatismo necessário que o tempo político da gestão governamental exige.

\section{Os significados do "técnico"}

O termo "técnico" é geralmente utilizado para denominar uma função de profissionais geralmente de nível superior de diversas categorias, que desempenham atividades específicas dentro de uma instituição. Assim, encontramos o seu emprego tanto na área assistencial, técnicos de um Centro de Atenção Psicossocial-CAPS, por exemplo, como na gestão. Na SESAB, assim como em outras instituições governamentais (municipais ou estaduais) todos os profissionais de nível superior que não ocupam funções de Direção, Coordenação ou suas Assessorias são denominados de técnicos.

No entanto, com o tempo fomos percebendo que o termo "técnico" tinha outros significados para além de simplesmente denominar uma função dentro da instituição. Por não ocupar um cargo de Direção (diretor, coordenador ou assessor) o técnico geralmente se colocava em um patamar diferente daqueles, visivelmente inferior quando se tratava da tomada de decisões. Antagonicamente à função de "técnico", os profissionais que ocupavam cargos de direção, eram vistos como tendo uma função "política", pois, de fato, ocupavam aqueles cargos por uma decisão do Governo. Assim, encontramos uma instituição onde as informações estratégicas e as decisões circulavam em uma esfera "política", enquanto as ações operacionais eram 
executadas por uma esfera "técnica", menos empoderada e consequentemente menos envolvida com o projeto político da instituição.

O técnico é aquele profissional que possui um saber específico sobre o funcionamento dos serviços, dos parâmetros, das normas, etc., um saber técnico mas ao qual não está associada uma capacidade de decidir sobre as políticas, pois este seria um conhecimento acessível somente àqueles que assumiam funções de Direção. Cabia ao técnico realizar visitas e dar pareceres que não seriam necessariamente acatados, pois, em última instância, as decisões dependiam de uma esfera política da qual o mesmo não fazia parte. Ou seja, corria-se sempre um grande risco do parecer do técnico não ser acatado e seu trabalho não ser valorizado. Por outro lado, o técnico também é aquele que está vinculado à instituição pois geralmente é um profissional concursado diferente da função de Direção que está vinculada ao Governo. Um técnico pode ocupar uma função de Direção durante um determinado Governo e assim assumir outro papel por um período, com maior delegação para decidir e participar das decisões.

Qual a consequência destas relações? Porque nos chamou tanta atenção estes significados do lugar do "técnico"? Percebemos que esta diferenciação, fortemente instituída, tinha importante impacto no envolvimento dos técnicos com o cotidiano da gestão na Diretoria. Os técnicos viam-se menos como gestores, limitando o envolvimento e a criatividade de cada um no cotidiano do seu trabalho. Esta situação também facilitava a desresponsabilização com alguns processos, não sendo incomum ouvirmos a expressão: "Sou somente um técnico" para justificar o não enfrentamento de alguns conflitos ou uma menor participação em agendas que demandavam tomada de decisão. A Instituição reforçava este papel, na medida em que muitas vezes não reconhecia a legitimidade da presença do técnico em determinadas espaços reuniões, grupos de trabalho, pois se tratava de um profissional com baixa capacidade de decisão. Ou seja, a separação entre "técnico" e "político" ou técnico e gestor era uma característica comum a toda a Instituição e não só da Diretoria da Rede Própria.

Acreditamos que essa cisão resultou do modelo gerencial hegemônico, que determina uma hierarquia muito bem marcada e vertical, de organização Taylorista (CAMPOS, 2000), dividindo a instituição entre aqueles que decidem e os que executam. Ao mesmo tempo, percebemos que essa característica do modelo foi reforçada e alimentada pelos próprios trabalhadores, como um mecanismo de "sobrevivência organizacional", pois não eram raros os relatos de desafetos dos que ali já trabalhavam há muitos anos. Assim, ser somente "técnico" poderia ser uma forma de evitar exposições e enfrentamentos, presentes no cotidiano da gestão.

Este cenário esvaziava do papel do técnico sua função gestora, sobrecarregava aqueles em função de Direção e empobrecia a interação da equipe de técnicos da Diretoria com as equipes das Unidades de Saúde, reduzindo sua capacidade de intervenção e apoio junto às Unidades. Por isso nos causava tantos incômodos, especialmente por entendermos que todos os atores em cena governam, todos planejam, todos fazem gestão de seu processo de trabalho, do seu cotidiano, da sua vida (MATUS, 1996). Todos têm uma liberdade importante no seu fazer e usam os poderes (saberes, entre outros) para operar nesse cotidiano. Por fim, todo trabalhador usa seu trabalho vivo na produção de certos produtos e com certas direcionalidades, que não necessariamente são os da organização. Ou seja, mesmo diante de uma estrutura organizacional que não privilegia os saberes e a participação de todos, os profissionais têm a 
possibilidade de agir com graus diferentes de liberdade no cotidiano do seu trabalho. Abrir espaço para este potencial era fundamental para qualificar o trabalho em nossa Diretoria.

Dessa forma, construir coletivamente outro "fazer" para essa equipe de profissionais da Gestão da Rede Própria da Bahia tornou-se, para nós, muito mais do que a organização do processo de trabalho para um funcionamento mais adequado da equipe, utilização melhor dos recursos ou acolhimento mais qualificado das demandas dos hospitais e unidades especializadas. A construção de outro "fazer", baseada no Apoio Institucional, significava romper com um passado de captura do trabalho vivo das pessoas e anulação ou sufocamento das diferenças, invenção e criatividade que todos possuem. Era a afirmação de outra ética, estética e política de existir enquanto gestor e trabalhador de saúde no SUS.

\section{De Técnicos a Apoiadores}

Começamos, então, a construir a proposta de organização da Diretoria da Rede Própria sob Gestão Direta, implantando o Apoio Institucional nas Unidades da Rede Própria, incluindo uma intensa agenda de Educação Permanente $\neg$ EP $\neg$ (MERHY; FEUERWERKER, 2014). Alguns dos novos membros da equipe traziam saberes adquiridos com a experiência de Apoiadores Institucionais ou coordenadores de equipes de Apoio em diferentes redes de atenção (Atenção Básica, Urgência e Emergência, Atenção Especializada e Hospitalar) desenvolvidas em um município do estado de Sergipe ou em municípios baianos.
Estas experiências anteriores ajudavam a perceber que, para desenvolver as agendas estratégicas colocadas para a nova gestão do Estado, bem como criar um processo de gestão mais participativo e comprometido com a formação de sujeitos, seria necessário conformar um novo ator na equipe de técnicos da Rede Própria, ator este com maior poder de interlocução junto às equipes das Unidades de Saúde, mais envolvimento com a formulação de políticas e agendas estratégicas e maior capacidade de decisão, mesmo que realizada dentro do nível de hierarquia que o organograma de uma instituição complexa e tradicional comporta. Precisávamos de mais gestores, não somente de "técnicos".

Assim, construímos o pacto de apostar na transformação de uma equipe de técnicos para uma equipe de Apoiadores. Ou seja, institucionalmente não deixariam de ser técnicos, mas passavam a desenvolver a função de Apoiador, deixando de lado o significado tradicional de "técnico" discutido anteriormente, para dar espaço a uma maior implicação e comprometimento com os diversos processos de gestão envolvidos na Diretoria, incorporando, ao mesmo tempo, uma maior participação nas decisões e definições dos projetos da Diretoria.

Apostamos em rodas de discussão e processos de Educação Permanente que passaram a fazer parte do cotidiano da gestão da equipe da Diretoria $\neg$ DIRPGD, debatendo os conceitos de "Técnico", Político, Apoiador e Supervisor. Trabalhamos com textos de diversos autores em reuniões que variavam de periodicidade semanal ou quinzenal, bem como em oficinas para este fim. Fizemos leitura e conversamos sobre teorias que nos ajudassem a compreender que todo ator em situação governa e que assim precisávamos superar a dicotomia entre "técnico" e "político". Conversamos sobre o projeto político-sanitário 
do novo Governo para as unidades da Rede Própria e percebemos identidade do grupo com a nova proposta, bem como sobre os conhecimentos necessários para desenvolver o Apoio Institucional às unidades hospitalares e especializadas. Os problemas do cotidiano eram fonte de estímulo para estudo coletivo desenvolvido por processos de Educação Permanente em Saúde.

Não havia dúvida de que as Unidades da Rede Própria precisavam de apoio entendido como uma ajuda no fazer com o outro pois havia um passivo de muitos anos com pouco ou nenhum investimento em muitas delas. Essa situação gerava angústia na equipe da Rede Própria, mas também foi uma condição que facilitou a identidade com as novas funções. Além disso, estava posto não somente a necessidade de conversar sobre infraestrutura dos serviços, mas principalmente sobre o processo de trabalho das equipes de saúde das Unidades de Saúde e a forma como se dava a produção do cuidado nas mesmas, um cuidado atravessado pelos interesses das corporações, do saber especializado, da indústria médica/farmacêutica e de equipamentos, sendo desse modo, uma produção do cuidado pouco permeável aos interesses dos usuários.

À medida que desenhávamos com a equipe as características deste novo personagem (técnicos na função de Apoiadores), fomos identificando também as limitações e demandas que o grupo colocava para assumir aquele novo lugar. Algumas demandas não estavam evidentes e precisavam ser percebidas e/ou sentidas por nós e devolvidas para pactuação com o grupo. As características do Apoiador estavam relacionadas com a expectativa da gestão central quanto aos mesmos, à expectativa dos gestores das unidades e, à expectativa do próprio Apoiador para atender à demanda da Rede de Petição e Compromissos construída com a SESAB e com as Unidades de Saúde. Era necessário que o Apoiador operasse com tecnologias e ferramentas que dessem conta dos saberes, poderes e afetos (CAMPOS, 2000) necessários ao seu trabalho, e assim identificamos as seguintes necessidades:

- Saberes: era necessário ampliar o conhecimento da equipe sobre temas específicos da Atenção Hospitalar, bem como sobre os novos paradigmas em discussão, como a desospitalização, por exemplo. Era necessário ter novos saberes para ofertar nas interações com os serviços. Além disso, as distintas políticas para as áreas de Saúde da Mulher e da Criança, Saúde Mental, Alta Complexidade, Urgência e Emergência, etc. demandavam um estudo das mesmas, para então pensar o papel de unidades especializadas nestas Redes. Além da organização de um cronograma de formação dentro das ações de Educação Permanente, também dividimos a equipe de Apoiadores em Coordenações, organizadas com base no tipo das Unidades, que implicavam em agendas específicas: Maternidades; Hospitais de Urgência e Pronto Atendimento; Centros de Referência; Hospitais Especializados; Hospitais do Interior.

- Poderes: era necessário mais do que reconhecer que todos os atores governam. Foi importante mapear os recursos que a equipe precisava controlar para relacionar-se com as Unidades de Saúde. Identificamos que a capacidade de fazer ofertas - informações sobre projetos, saberes específicos da gestão hospitalar, retorno de demandas anteriores, acesso a informações, etc. - legitimava a equipe de Apoiadores junto à Direção das Unidades. Da mesma forma, a capacidade de resposta rápida a determinados pedidos empoderava a equipe no controle de alguns processos internos. Assim, organizar a informação passou a ser fundamental, bem como monitorar o andamento de ações estratégicas (como contratação de pessoal) para manter as Unidades informadas e planejar a ampliação e mudança de serviços. 
Nesse período constituímos o Núcleo de Informação da DGRP, responsável por instrumentalizar o Apoiador com informações para discussão e monitoramento de ações das Unidades.

- Afetos: o trabalho do Apoiador deve lançar mão de saberes e tecnologias comuns ao trabalho desenvolvido no mundo do cuidado em saúde como a escuta, acolhimento, vínculo, construídos através de espaços de intercessão e troca entre Apoiador e equipe apoiada. Ou seja, neste novo lugar proposto pelo Apoio, o roteiro ou a planilha são recursos que contribuem para organização do trabalho, mas não são orientadores do mesmo. A escuta está além dos instrumentos estruturados e mesmo além do que é efetivamente verbalizado. Da mesma forma, o espaço intercessor (MERHY, 2002) é o espaço de negociação entre atores, de construção de pactos e de produção para os envolvidos, através de uma relação de trocas. Este era outro conhecimento esperado e buscado pela equipe, - conhecimento das tecnologias leves no campo da Micropolitica. (MERHY, 2002)

Um processo rico foi se conformando, produzindo aproximação entre toda a equipe. No entanto, a receptividade à proposta de uma mudança foi muito heterogênea, sendo que alguns recusaram a mesma. Sair do lugar tradicional do "técnico" implicava um maior compromisso com determinados processos, que anteriormente eram concluídos após a entrega do parecer do técnico ao seu Coordenador ou Diretor. Implicava uma maior responsabilidade na interlocução com os diretores de Unidades de Saúde, pois o Apoiador falava não mais do lugar individual de seu saber específico, mas sim em nome de uma política e de diretrizes pactuadas junto ao Nível Central da Secretaria. Por fim, também implicava em uma maior participação em reuniões da Diretoria $\neg$ DIRPGD, com o objetivo de participar de determinadas decisões bem como ter acesso à socialização das mesmas.

Sem partir de velhas práticas, a priori, de "resistentes à mudança", tentamos trabalhar essa questão buscando acolher os incômodos, o que nem sempre era possível por conta das agendas e da própria distância inicial que havia entre nós. Abordamos este tema em muitos espaços e momentos. No processo, alguns técnicos solicitaram sua remoção da Diretoria. Ao mesmo tempo, recebemos pedidos de remoção de profissionais de outras áreas para ingressarem em nossa Diretoria, referindo que estavam ouvindo boas informações sobre o processo que vinha se desenvolvendo naquele setor. Tivemos muitas mudanças na equipe, mas a maioria dos profissionais originários da Diretoria permaneceu conosco durante todo o projeto. Adquirimos novos e verdadeiros companheiros no encontro entre jovens sanitaristas participantes do Governo e antigos servidores estaduais de carreira do Estado.

Curiosamente, como resultado deste processo de negociação a este novo modo de fazer a gestão, o termo Apoiador foi rejeitado pela equipe, preferindo identificar-se como Supervisor. Pactuamos que a denominação deveria ser aquela que deixasse a equipe mais confortável, tendo sido escolhido o termo "Supervisão da Rede Própria", mas que as ações deveriam ser aquelas que construímos como papel do Apoio Institucional. Dessa forma foi-se constituindo a equipe de Supervisores/ Apoiadores da Rede Própria, através do tempo com uma intensa mudança do processo de trabalho desenvolvido internamente na Diretoria e também na relação com as Unidades da Rede Própria. A equipe de Apoiadores chegou a contar com até vinte e seis membros com carga horária em média de trinta horas semanais. 


\section{O papel da Educação Permanente}

A Educação Permanente (EP) foi a principal orientadora deste processo, presente nos espaços colegiados de gestão, nas reuniões de Diretoria, nas visitas dos Apoiadores às Unidades e na problematização cotidiana direcionada para movimentos autoanalíticos, buscando um aprendizado com o próprio fazer cotidiano. Para facilitar nosso relato destas atividades, dividimos as ações de EP de acordo com o processo na qual estava envolvida:

- EP nos Espaços Colegiados de Gestão: reunião de Diretoria, reunião de Coordenações e Reuniões Ampliadas dos Apoiadores se constituíram em potentes espaços de EP. A gestão colegiada permitiu que membros da equipe do Apoio estivessem mais presentes em momentos de decisão de agendas específicas, também passando a conhecer mais sobre determinadas pautas. A pausa em algumas discussões para aprofundar reflexões sobre os melhores caminhos para compartilhar de experiências, era frequente. A participação nestes espaços permitia também que os novos Apoiadores conhecessem e vivenciassem processos de mediação em reuniões com pautas e produtos bem definidos, pois os mesmos deveriam ser fomentadores de ações semelhantes junto às Unidades.

- EP no cotidiano do Apoiador: a vivência de um novo papel pela equipe naturalmente passou a ser produtora de novas questões e inseguranças cotidianamente. A capacidade de acolher novas demandas dos Apoiadores era uma necessidade da gestão, para que os mesmos pudessem exercitar sua alteridade e compreender que Acolhimento é tecnologia que deve estar na "caixa de ferramentas" do Apoiador. Assim, conformamos um espaço de reunião quinzenal para conversas específicas sobre certas necessidades do cotidiano, com leituras e discussões complementares à formação com a consultoria. Ao mesmo tempo foi interessante perceber que a troca de experiências entre os próprios Apoiadores passou a ser um recurso para a equipe, que se apoiava mutuamente em determinadas ações.

- Formação dos Apoiadores a contratação de uma consultoria externa foi uma ação importante para oferecer conteúdos específicos sobre a gestão de unidades especializadas, como hospitais. O domínio de determinadas ferramentas específicas neste nível de atenção ainda era um problema identificado junto à equipe e, portanto, essas ferramentas foram ofertadas. Neste espaço também debatemos a natureza do cuidado na Atenção Especializada e as características dos saberes e poderes envolvidos nas relações entre trabalhadores e entre trabalhadores e usuários (CECÍLIO, 2003).

As discussões de textos eram muito interessantes, pois nos possibilitavam uma reflexão e debate sobre o universo de problemas do contexto do SUS na Bahia, onde nem todos tinham ainda uma visão de Rede, visto que muitos Apoiadores vinham de uma prática da assistência direta ao paciente/ usuário, não debatendo sobre a questão das Redes de Atenção à Saúde. A cada semana a avaliação destas atividades traziam relatos sobre uma satisfação cada vez maior nesses encontros, embora às vezes nem todos conseguissem fazer a leitura antecipada dos textos trabalhados, pois com o avanço da EP, estes também aumentavam de número e, consequentemente, aumentavam as atividades, já que apesar de estarmos em processo de construção de uma nova prática, precisávamos responder às demandas da Instituição.

Vale ressaltar que outro aspecto importante destacado pelo grupo foi a participação das figuras do Diretor, Assessor da Diretoria e Coordenadores nos espaços 
de EP. Havia a possibilidade de conversar sobre os projetos concretos da Diretoria contextualizando a discussão teórica, além de horizontalizar as relações tradicionalmente tão hierarquizadas.

A Educação Permanente era um conceito novo para alguns membros da equipe de Apoio da Rede Própria e foi necessário que a equipe pudesse ver a coordenação atuando como Apoio ao Apoiador, para compreender que tipo de relação poderia ser construída com a gestão das Unidades acompanhadas. Foi um desafio construir uma agenda semanal que pudesse contemplar os momentos de encontro e reuniões na frequência em que eram necessários, e ao mesmo tempo executar as demais ações do Apoio, pois ainda permaneciam as agendas estruturadas e as horas consumidas para dar pareceres técnicos em processos ocupavam muito o tempo da equipe.

Outro recurso utilizado foi lançar mão de conhecimentos específicos de alguns Apoiadores, compartilhados em momentos oportunos. Por exemplo, a equipe que acompanhava as maternidades tinha um saber específico na área de políticas de saúde maternoinfantil que poderiam ser compartilhadas com a equipe de Apoiadores dos hospitais do interior, que também possuíam maternidades por serem hospitais gerais. Porém, nem sempre aquele Apoiador dominava o saber específico para realizar ações do Apoio, assim agendavam-se conversas sobre temas específicos que um determinado Apoiador dominava, compartilhando com os colegas.

Por fim, a consultoria de profissionais com ampla experiência na gestão e no cuidado desenvolvido na área hospitalar foi muito importante, não somente para contribuir com a formação da equipe, mas também para apoiar a equipe de Direção. Muitas eram as dúvidas sobre como enfrentar situações de incerteza, sobre a proposta de gestão da equipe e da Rede de Própria, bem como os projetos para Unidades específicas e as dificuldades inerentes ao fato de estar na Gestão Estadual de um território tão vasto e importante como é a Bahia.

\section{A atuação do Apoiador da Rede Própria}

A implantação do Apoio Institucional na Rede Própria foi um processo que teve início no momento que começamos a considerar a possibilidade de reorientação do trabalho da equipe de técnicos em conjunto com os mesmos, foi aí que se deu o início do Apoio na Rede Própria. No entanto, consideramos como referência o primeiro semestre de 2008, momento em que identificamos o amadurecimento da estrutura de gestão da Diretoria, na medida em que a interação dos Apoiadores com as unidades ia aumentando.

Percebemos que a heterogeneidade das Unidades e um certo grau de criatividade, seria algo presente no trabalho da equipe. A grande variedade de Unidades não permitia uma relação com grande semelhança entre elas. Assim, a construção de uma "Carta de Demandas" nem sempre construída com esta denominação foi um dos dispositivos utilizados para organizar a agenda junto com algumas Unidades. Alguns hospitais demandavam mais presença do Apoiador para discutir questões estruturais ou para facilitar o andamento de processos importantes. Com outras Unidades fomos avançando na discussão sobre o processo de trabalho das equipes e o cuidado ofertado aos usuários. Em outras ainda mantínhamos uma relação mediada por pautas originadas fora da Rede Própria, como a implantação de projetos específicos. Por fim, havia também hospitais pouco abertos à entrada da equipe de 
Apoiadores. Optamos, na medida do possível, por respeitar o movimento das Unidades e organizar a agenda por meio de "Cartas de Demandas" construídas na interação com os serviços. Onde éramos pouco desejados, interagíamos mais pontualmente. E assim, fomos fortalecendo vínculos gradualmente.

A experiência de forçar a relação com determinados serviços, não respeitando a autonomia da Direção da Unidade, foi desastrosa, fechando o espaço para o trânsito do Apoiador e produzindo desconfiança em ambos os lados. Na relação de Apoio, como na relação de cuidado, a produção de vínculo é fundamental. Sem confiança não há vínculo.

A partir das demandas das Unidades, os Apoiadores Institucionais introduziam novas agendas de discussão, pactuando respostas dos resultados das ações consideradas estratégicas no projeto para a Saúde do Estado da Bahia. A equipe do Apoio negociava a adesão, fazia pactos e comprometia-se também com alguns resultados. Assim, foi possíveliniciar debates como: a implantação de "Acolhimento com Classificação de Risco" em algumas Unidades; Gestão da Informação voltada para a ocupação e rotatividade de leitos; estímulo à criação de espaços de gestão colegiada nas Unidades; definição do papel e articulação das Unidades com a rede locorregional; reorganização do processo de trabalho de serviços específicos em determinadas Unidades. Além disso, o debate sobre novos recursos (equipamentos e obras) passou a ser realizado no contexto dos projetos pautados pela Diretoria, na interlocução com outros setores da SESAB.

As ferramentas estruturadas, questionários e parâmetros continuaram sendo valorizados e buscamos uma maior organização dos mesmos, facilitando o trabalho do Apoiador quando se demandava este tipo de saber. No entanto, nos momentos de EP sempre provocávamos os trabalhadores com questões que colocassem os parâmetros em "xeque", para não sermos capturados pelos mesmos, e pudéssemos construir ou buscar novos parâmetros que dialogassem com a necessidade do momento.

\section{O que ficou}

A perspectiva de produção de uma relação diferente com as Unidades e com os processos anteriormente desenvolvidos produzia uma agitação na equipe e em todos nós. Eram muitas ações desenvolvidas naquele setor e muitas expectativas. Recordando agora, percebemos como o volume de trabalho era grande. Podemos dizer que foi uma experiência cansativa, mas prazerosa. Eram frequentes os relatos de satisfação de muitos dos Apoiadores que compartilhavam conosco aquele cotidiano, ao mesmo tempo em que traziam suas inseguranças e dúvidas das novas atribuições.

Ao longo desses dois anos compartilhamos muitos depoimentos de colegas com décadas de serviço no Estado, que haviam percorrido diversos setores e Unidades, conheceram muitos gestores e presenciaram relações de grande autoritarismo, relatando com satisfação a possibilidade de participar de um projeto onde podiam ouvir e falar, tendo como tarefa o estímulo a que os colegas das Unidades de Saúde também pudessem fazer o mesmo, construindo novos caminhos a partir destas conversas. Sem dúvida, a possibilidade de troca entre as distintas pessoas que fizeram parte deste processo, novos e antigos servidores, foi uma das grandes riquezas e satisfações que experimentamos. 
Ainda, como sentimento, ficou a satisfação por termos ousado na disputa por um projeto de inclusão das pessoas nos processos de gestão e decisão, em uma área tão "dura" como a gestão especializada e hospitalar, em que o processo estruturado é considerado o essencial, e que a viabilização de mais recursos equipamentos, obras, recursos humanos, é a principal resposta esperada do nível central. Sem esquecer também da angústia que às vezes, transformava-se em sofrimento para dar conta das demandas emergenciais cotidianas que desestruturavam agendas e pactos, prejudicando o andamento dos novos projetos, exigindo criatividade e capacidade de improvisação para avançar sem negar as prioridades pautadas pelas crises do dia a dia. Mas isso também foi um componente que aproximou o coletivo, aumentando a cumplicidade diante das situações críticas, pois só com solidariedade é possível enfrentar certos desafios.

No fim do ano de 2009, a equipe que ocupava os cargos de Direção deixou a DIRPGD para dedicar-se a outras atividades. Alguns membros da equipe do Apoio Institucional sentiram-se órfãos, não sendo possível dar continuidade aos espaços de EP constituídos. Não cabe aqui analisar os motivos desta não continuidade, que certamente tem diversas variáveis envolvidas. Todavia, o mais significativo é compreender como se deu o processo e o que ficou para aqueles que participaram do mesmo.

Para nós, autores deste texto, foi uma vivência singular, pela tensão entre a grande demanda e a necessidade de manter a agenda desejada diante das agendas críticas como superlotação de emergências e déficits de recursos foi também um momento de grande aprendizado. Certamente, tomaríamos algumas talvez várias decisões diferentes. Isso não quer dizer que seriam melhores, pois só podemos saber efetivamente dos resultados quando eles acontecem. Não é assim na própria vida? Reconstituir os passos e refletir sobre o acontecido nos ajuda a pensar no que ainda pode vir a ser, em situações semelhantes de novas experiências.

O Apoio Institucional às Unidades de Atenção Especializada, em especial hospitais, é ainda um grande desafio, pois envolve distintos conhecimentos e onde os saberes das corporações atuam de forma muito intensa. Mediar ações neste contexto demanda a construção de redes dentro das próprias Unidades, capazes de produzir mudanças a partir das articulações dos muitos atores existentes nestes serviços.

A experiência de Apoio Institucional na Rede Própria serve para que outros companheiros que atuam em espaços semelhantes possam ser "contaminados" com novas possibilidades de um trabalho em saúde centrado no "trabalho vivo", voltado para a produção da autonomia, em processos participativos e includentes.

\section{Referências}

BONDÍA, J. L. Notas sobre a experiência e o saber de experiência. Revista Brasileira de Educação, n.19, p.24, jan./abr. 2002.

CAMPOS, G. W. de S. Um método para análise e cogestão de coletivos. São Paulo: Hucitec, 2000.

CECÍLIO, L.C.O.; MERHY, E.E. A Integralidade como Eixo de Gestão Hospitalar. In: Pinheiro, R.; Mattos, R.A. (org.). Construção da Integralidade: cotidiano, saberes e práticas em saúde. Rio de Janeiro: Editora IMS, UERJ, ABRASCO, 2003.

MATUS, C. Política, Planejamento e Governo. 2. ed. Brasília: IPEA, 1996. 
MERHY, E.E. Saúde: a Cartografia do Trabalho Vivo. São Paulo: Hucitec, 2002.

MERHY, E.E.; FEUERWERKER, L. C. M. Educação Permanente em Saúde: educação, saúde, gestão e produção do cuidado. In: MANDARINO, A. C. S.; GOMBERG, E. (Org.). Informar e Educar em Saúde: análises e experiências. Salvador: Editora da UFBA, 2014. No prelo.

MERHY, E.E.; FRANCO, T.B. Por uma Composição Técnica do Trabalho Centrada nas Tecnologias Leves e no Campo Relacional. Saúde em Debate, Rio de Janeiro, v.27, n. 65, set./dez. 2003.

MERHY E.E. et al. Em busca de Ferramentas Analisadoras das Tecnologias em Saúde: A Informação e o dia-a-dia de um Serviço, Interrogando e Gerindo Trabalho em Saúde. In: MERHY, E. E.; ONOCKO, R. (org.). Agir em Saúde : um desafio para o público. São Paulo: Hucitec, 1997.

\section{Processo de trabalho e diferentes modalidades de Apoio do NASF no Município do Oeste Baiano}

Alan Jonh de Jesus Costa

Este texto é dedicado às amigas Marilda Bastos, Joceli Sousa, Simone Rodrigues, Claudete Oliveira, Cintia Nazarella, Licia Sola e Catiane Cardoso que dividiram comigo não apenas seus saberes mas a amizade e alegria de suas almas.

\section{A implantação do NASF}

Minha experiência no Núcleo de Apoio a Saúde da Família (NASF) em Município do Oeste Baiano iniciouse em dezembro do ano de 2010, quando me tornei integrante de uma equipe multiprofissional composta por assistente social, professor de educação física, psicóloga, fisioterapeuta e nutricionista, com objetivo de apoiar nove equipes de Saúde da Família (SF).

A primeira pergunta que veio à minha mente 
foi a seguinte: como seria esse Apoio? Como equipe, precisávamos antes de tudo lidar com as limitações que alguns de nós tínhamos sobre o conceito de Saúde Pública/Saúde Coletiva e a falta de conhecimento de como construiríamos este apoio junto às equipes SF. Foi um período riquíssimo de aprendizado, e fantástico no sentido de amadurecimento do trabalho na Estratégia Saúde da Família, especialmente no tocante à organização de ações compartilhadas e no aprimoramento individual para atuação com as diferentes modalidades de Apoio, requeridas conforme as necessidades identificadas nas situações do cotidiano.

Esse aprendizado proporcionou uma enorme alegria ao recordar dos ricos momentos de planejamento e desenvolvimento das ações em equipe (essa foi para a maioria de nós a primeira experiência de trabalho em uma equipe multiprofissional); das satisfatórias sensações vivenciadas quando dos resultados positivos alcançados junto à comunidade e/ou às equipes; das diversas reuniões em que juntos problematizávamos o que fazer e como fazer; e que tivemos que realizar mudanças de trajetórias para nos adequarmos às necessidades apontadas pelos usuários e trabalhadores das equipes de Saúde da Família.

No momento de implantação do NASF o Município contava com apenas doze equipes de Saúde da Família e nove Unidades Básicas de Saúde. A maioria das equipes apoiadas pelo NASF tinha como atividades centrais as ações curativas em detrimento da promoção e prevenção. Já a população adstrita a estas Unidades apresentava como problemas de saúde mais comuns: hipertensão, diabetes, doenças e transtornos mentais, dependência ao uso de álcool e outras drogas, e as enfermidades ligadas à baixa cobertura de saneamento, e à vulnerabilidade econômica, social e educacional.
Desse modo, a missão do NASF seria contribuir para o aumento da resolutividade das ações da Estratégia Saúde da Família apoiando e compartilhando as responsabilidades.

Uma vez recebidos pela Coordenadora da Atenção Básica e apresentados à enfermeira que assumiria a coordenação da equipe de NASF, passamos enquanto grupo a ocupar uma sala da própria Secretaria da Saúde do Município, local este onde eram realizadas atividades de planejamento e avaliação das ações.

Inicialmente, nossas atividades foram desenvolvidas no sentido de orientação e organização do nosso processo de trabalho: voltava-se para leitura e discussão em conjunto dos documentos oficiais sobre o NASF, elaborados pelo Ministério da Saúde (MS) e pela Secretaria da Saúde do Estado da Bahia, confecção de panfleto explicativo, e de visitas de apresentação desse Núcleo às nove equipes sob sua cobertura.

Durante as visitas eram realizadas a apresentação dos profissionais, do papel do Núcleo de Apoio à Saúde da Família, e um exercício de levantamento cartográfico junto à equipe, sendo afirmado por diversas vezes que a Equipe NASF não estava ali necessariamente para fazer atendimento direto aos usuários, o que acabou gerando certo clima de dúvida e instabilidade entre os atores.

É importante salientar que pelo fato de durante as visitas estarmos acompanhados pela Coordenadora do NASF, pessoa já conhecida na Gestão, os profissionais das equipes ficaram em dúvida se o NASF não era então gestão já que não veio para suprir as suas necessidades imediatas de atendimento individual aos usuários devido à demanda reprimida ocasionada pela falta destas categorias profissionais nos serviços de especialidades. Este entendimento perdurou por um longo tempo. 
Além disso, foi possível também constatar que os profissionais das equipes de Saúde da Família não tinham qualquer conhecimento sobre o papel a ser desempenhado pelo NASF, e que a maioria das equipes estavam distantes das lideranças e dos aparelhos sociais da comunidade. Todos estes fatores identificados tornaram-se um grande desafio a superar, uma vez que tínhamos em mente que não poderíamos avançar no objetivo maior do NASF que seria o Apoio Matricial, se as equipes de Saúde da Família tinham uma convicção diferente da nossa atuação.

[...] arranjo organizacional ou modalidade de prática do apoio na qual um conjunto de saberes, de práticas e/ou de competências concentrados em certos setores, grupos ou indivíduos de uma organização, considerados necessários para resolução de demandas ou problemas expressos por outras parcelas da organização, é ofertado a estas últimas por meio de processos que incorporem uma metodologia de apoio. Toma como objeto uma necessidade ou um problema vivenciado. Nesse sentido é que entendemos que o seu enfoque é mais clínico, mas sempre considerando que há dimensões de gestão em jogo (OLIVEIRA, 2011, p. 46- 47).

Dessa forma, nos debruçamos na elaboração de projetos de intervenção a serem apresentados às equipes, e no desenvolvimento de uma pesquisa de campo. A realização deste estudo foi de grande importância para a equipe porque foi a partir do levantamento do perfil epidemiológico das comunidades a serem assistidas que gerou visitas a $50 \%$ das famílias, com a coleta de dados e o conhecimento dos condicionantes gerais de vida e saúde, que possibilitou o estabelecimento dos primeiros vínculos entre equipe e usuários.
Outro movimento de construção da equipe foi o de elaboração de uma agenda de trabalho a ser apresentada às equipes de Saúde da Família- SF. Para esta construção foi solicitado que cada equipe enviasse sua agenda semanal de trabalho; ao recebermos essas agendas, pudemos identificar que a maioria das equipes SF tinham seu processo de trabalho centrado na queixa conduta, com utilização de ferramentas duras e leve-duras ${ }^{1}$, com ausência de atividades de promoção e poucas atividades de prevenção (apenas uma equipe tinha grupo estruturado).

O primeiro produto da discussão de elaboração da agenda por parte da equipe NASF foi uma agenda prévia, composta pelosseguintes elementosestruturantes: reuniões internas de equipe; reuniões mensais com as equipes SF; atividades de grupos; visitas domiciliares; educação em saúde, organizados numa agenda permanente de atividades distribuídas pelos turnos da semana. Nossa análise naquele momento partia do entendimento que deveríamos ter uma agenda fixa, que desse conta de participar do cotidiano das equipes, contemplando também a nossa presença em suas reuniões semanais.

Contudo, logo percebemos que o modelo proposto estava deslocado da realidade, e que existiriam diversas barreiras para construção desse fazer compartilhado: (1) as equipes não tinham cultura de realizar reunião de planejamento/ avaliação e quando estas ocorriam eram simplesmente para o repasse de indicadores; (2) não existia uma cultura de discussão de casos, de construção de projetos terapêuticos singulares (PTS) ${ }^{2}$ e/ou projetos

${ }^{1}$ Segundo Emerson Merhy et al. (1997) e Merhy (2002) o trabalhador de saúde pode orientar suas ações a partir de três tipos de tecnologias: tecnologias leves, associada as relações de produção de vínculo, autonomização, acolhimento e gestão; tecnologias leve-duras, que seriam os saberes já estruturados; e as tecnologias duras as máquinas, as normas e as estruturas organizacionais.(MERHY, 1998; 2002).

2 PTS - Projeto Terapêutico Singular $\rightarrow$ São projetos de intervenção 
saúde no território (PST) ${ }^{3}$; (3) os profissionais não estavam acostumados a realizar ações de forma compartilhada e alguns se negavam a fazer isso; (4) a Gestão Municipal não realizava acompanhamento do processo de trabalho das equipes (realizava-se apenas uma reunião mensal, muito mais para recolher os consolidados de produção das equipes e dar os recados necessários); (5) as equipes enfrentavam dificuldades de condições de trabalho que geravam resistência às mudanças; (6) existência de uma vulnerabilidade muito grande do processo saúde-doença das comunidades assistidas.

Por sua vez a equipe NASF não tinha experiências anteriores com a organização de agenda, e nós não sabíamos exatamente como atender de forma equitativa todas as Unidades sob nosso apoio e abrangendo um maior leque possível de ações: visitas domiciliares, atividades educativas na comunidade, reuniões com as equipes SF, interconsulta ${ }^{4}$, participação em atividades de grupo, interlocução da rede, etc.

desenvolvidos para um indivíduo e ou família É dividido em quatro tópicos: diagnóstico, levantamento de ações a serem desenvolvidas, dos responsáveis e reavaliação das ações realizadas (BRASIL. Ministério da Saúde, 2008).

3 PST ᄀProjeto Saúde no Território $\neg$ são projetos de intervenção organizados pela equipe para dar resposta a um grande problema de saúde/doença da comunidade. Exemplo: projeto de combate à Dengue para uma comunidade (BRASIL. Ministério da Saúde, 2009a).

${ }^{4}$ São atividades de atendimento compartilhado em que a consulta é realizada por mais de um profissional buscando ampliação de saberes e competências na produção do cuidado daquela usuária. Normalmente atrelando diferentes núcleos profissionais. (Nota do autor)

\section{O processo de trabalho e as modalidades de Apoio}

A partir desse contexto a equipe NASF acabou absorvendo (processualmente sem que houvesse uma deliberação formal) a mudança do modelo de atenção das equipes de Saúde da Família como objeto central das suas ações, atrelando elementos da modalidade de Apoio Matricial; a modalidade de Apoio Institucional ${ }^{5}$ com ênfase na cogestão da clínica ; e do apoio assistencial direto ${ }^{7}$, o que gerou um percurso bastante peculiar, cheio de avanços e retrocessos.

No momento inicial, constatada a ineficácia de uma agenda rígida, decidimos fazer uma reunião com as

${ }^{5}$ A modalidade do Apoio Institucional se refere à produção de análise e interferência no processo de trabalho orientado pela cogestão e pelo desenvolvimento da autonomia. Instaurada no apoio do NASF nas reuniões de equipe para uma tomada de decisão sobre o processo de trabalho da equipe SF (fazer ou não fazer um projeto terapêutico, montar ou não montar um grupo, realizar ou não realizar uma atividade terapêutica e/ou de incentivo ao controle social em conjunto com a equipe NASF). Nas atividades de Educação Permanente organizadas em conjunto entre NASF- SF em que são tratados pela equipe NASF temas gerais do trabalho em saúde - Acolhimento, Humanização etc. Esta modalidade de apoio podem ser caracterizadas melhor nas ações que envolvem o campo - ou seja ações que todo profissional de saúde pode realizar (acolhimento, cartografia etc).( (Nota do autor)

6 No Brasil tem sido comum a expressão cogestão, cujo prefixo "co" designa duas inclusões, as quais alargam conceitualmente o que se entende por gestão. Em primeiro lugar, cogestão significa a inclusão de novos sujeitos nos processos de gestão (análise de contexto e problemas; processo de tomada de decisão). assim, ela seria exercida não por poucos ou alguns (oligo-gestão), mas por um conjunto mais ampliado de sujeitos que compõem a organização, assumindo-se o predicado de que "todos são gestores de seus processos de trabalho" (BRASIL, Ministério da Saúde, 2009b).

O apoio assistencial direto se expressa nas ações de clínica individualizada, em que um ou mais membros da equipe NASF realiza consulta com os usuários sem a presença de membros da equipe SF. Historicamente esta modalidade de apoio tem ocorrido na lógica ambulatorial realizada na rede especializada. 
coordenadoras das Unidades de Saúde para a discussão conjunta de uma proposta de agenda para a equipe NASF. Contudo, a proposta do espaço foi frustrante, devido à ausência de contribuições durante o encontro, o que foi analisado pela equipe como falta de entendimento do próprio papel do NASF.

Com essa realidade a equipe passou a adotar um modelo de representação/organização do processo de trabalho diário (agenda) consolidada por três instrumentos: um calendário anual onde se anotavam todos os compromissos fixos (reunião de equipe, atividade de grupo e oficina de capacitação) para os meses futuros; um grande calendário mensal onde se agendava todos os compromissos da equipe naquele mês, e um livro de ocorrência em que a equipe descrevia com riqueza de detalhes todas as ações e eventos ocorridos a cada dia. Essa medida solucionou as dificuldades de acompanhamento por parte dos profissionais das ações ocorridas em sua ausência, diante das diferenças de carga horária entre as categorias profissionais que compõem a equipe: Nutrição, Educação Física e Psicologia 40 horas, Assistência Social 30 horas, Fisioterapia 20 horas.

A partir desse ponto a equipe NASF realizou reuniões com cada uma das equipes SF levando como proposta a sua participação em uma reunião mensal da equipe $S F$, quando seriam discutidos os casos, apontadas novas ações e a avaliação das já realizadas em parceria, além de construção de um grupo em cada Unidade. Estas propostas foram aceitas e implementadas na maioria das Unidades (das nove equipes apenas uma não realizou a implantação do grupo).

No mês seguinte, a equipe NASF organizou uma oficina de capacitação das equipes de Saúde da Família, buscando abordar o conceito de processo saúde/doença, diferença entre promoção, prevenção e recuperação da saúde, relação interpessoal no trabalho de saúde, e, diferentes modelos de agenda em saúde. A nosso ver esta atividade seria uma forma de alinhar conceitos básicos da Saúde da Família, para que o entendimento da proposta do NASF pudesse ser facilitado.

A oficina de capacitação das Equipes de Saúde da Família foi a primeira atividade de Educação Permanente de caráter sistemático realizada pela equipe NASF e se concretizou de forma bastante positiva.

Vale a ressalva de que, a partir desta atividade observamos que a maioria dos profissionais possuía um conceito de saúde/doença fragmentado, estático, biologicista, e unicausal (entre eles os profissionais de nível superior), além de não apresentarem clareza quanto aos conceitos de promoção da saúde e prevenção de doenças, o que foi debatido e problematizado, fazendo-se referência à importância desses conceitos para atuação e definição das ações a serem desenvolvidas. Na oportunidade, ainda foram discutidos os pontos positivos e os limites da realização das ações de promoção da saúde e prevenção de doenças, relacionando-os à centralidade das ações de recuperação atribuídas no "fazer saúde" das equipes. Saímos dessa atividade com a sensação de que uma pequena semente havia sido plantada no interior de cada um dos profissionais que lá estavam.

Um ponto de entrave durante a oficina foi a discussão dos cronogramas das equipes. Apesar da maioria já possuir agenda elaborada, quase todas apresentaram limites para discuti-las. De maneira geral houve certa resistência em avaliar e problematizar a sua organização, mesmo tendo trabalhado com avanços e limites de diferentes modelos, de modo a descolar da ideia inicial de uma possível crítica direta ao processo de trabalho de cada Unidade. Com isso, 
foi observado que algumas mudanças são impossibilitadas não pela falta de acesso e compreensão de seus conceitos, mecanismos e condicionantes, e sim, por limites e barreiras consolidadas no processo e condições de trabalho que fazem com que os profissionais se fechem às mudanças pelo receio de aumento de demanda.

Além desse tipo de atividade de Educação Permanente mais sistemática, era comum levarmos para as reuniões das equipes temas a serem discutidos que provocassem a reflexão sobre o modelo de atenção das mesmas, como por exemplo: organização de uma reunião de equipe; conceito e realização de Projetos Terapêuticos Singulares e Projeto Saúde no Território; planejamento das ações com base na avaliação do perfil epidemiológico do território; cuidado com usuários de álcool e outras drogas; reuniões avaliativas com participação da comunidade.

Todavia, com o tempo fomos percebendo que os eventos de Educação Permanente vinham surtindo efeitos bem lentos na mudança de postura dos profissionais das equipes SF, ou seja, que as reuniões ocorriam prioritariamente com caráter de reunião de equipe quando estava agendada a participação do NASF, e que os grupos implantados ficavam sob responsabilidade quase exclusiva da equipe NASF. A equipe SF estava entendendo os grupos como do NASF e não como da equipe SF com apoio do NASF.

Nesse movimento, a equipe NASF passou a intensificar uma série de atividades, buscando ampliar a oferta de apoio às equipes SF, com destaque para: reuniões com técnicos da Diretoria Regional de Saúde para discutir uma proposta de aproximação dos profissionais de saúde do Município com os problemas ligados ao uso de álcool e outras drogas; agendamento de visitas domiciliares; realização de interconsultas; participação em salas de espera; organização de Projetos Saúde no Território; projeto
"Cuidador cuidando de quem cuida" (que eram oficinas realizadas nas Unidades para o cuidado dos próprios profissionais de saúde); participação em encontros e dias temáticos, como por exemplo: o dia do idoso, da mulher, da criança; visitas de interlocução da rede de serviços, além do apoio aos diversos grupos existentes.

Ainda, houve a participação na construção de Conferências Locais e Municipal de Saúde, de projeto de capacitação de professores ligados ao Programa "Mais Educação", de diversas palestras realizadas em espaços comunitários e de diversas reuniões na tentativa de articulação da Rede de Saúde Mental.

Apesar das diversas atividades desenvolvidas pela equipe NASF oriundas de convite e organizadas pelas equipes SF tínhamos um enorme incômodo ao perceber que boa parte das ações acima descritas aconteciam muito por indução do NASF nos espaços de reunião junto às equipes $\mathrm{SF}$, e que durante o decorrer dos projetos a execução das atividades acabavam sendo direcionadas prioritariamente aos trabalhadores do NASF. E, por vezes, se o NASF não assumisse o protagonismo das ações, estas não aconteciam, ou desviavam dos objetivos centrais pactuados e discutidos.

Assim, decidimos organizar uma Oficina de Educação Permanente ${ }^{8}$, discutindo a interação entre as equipes de Saúde da Família e a equipe do Núcleo de Apoio à Saúde da Família, abordando os debates conceituais como clínica ampliada, trabalho compartilhado e de abordagens de estratégias de cogestão do processo de trabalho das duas equipes.

Durante a realização dessa oficina um fato chamou a

${ }_{8}$ Educação Permanente era entendida pela equipe NASF como ações teórico-pedagógicas desenvolvidas para as equipe SF, abordando os fatores cognitivos, relacionais e atitudes visando a análise coletiva e a (re)organização do processo de trabalho. 
atenção: após cerca de uma hora de desenvolvimento da atividade com uma determinada equipe de Saúde da Família, passamos a perceber uma certa apatia nos participantes, falta de interesse no conteúdo e instabilidade na relação entre os participantes. Fomos obrigados pela situação a interromper a atividade e colocar na roda o problema que os afligia: existia um imenso conflito interpessoal na equipe que estava paralisando uma série de ações na mesma.

Desse modo, passamos a discutir com a Coordenação da Atenção Básica a necessidade de um acompanhamento mais próximo à equipe, e realização de visitas mais frequentes, no sentido de discutir o seu processo de trabalho.

Com o tempo, a Equipe do Núcleo de Apoio à Saúde da Família passou a realizar semestralmente um espaço de avaliação das ações e de planejamento das atividades com cada equipe de Saúde da Família, em que eram pactuadas as atividades de cunho permanente e os objetivos mais gerais da própria equipe SF e equipe NASF, mediante um levantamento do perfil epidemiológico da comunidade.

Todavia, apesar do esforço de readequação desenvolvido pela equipe NASF continuávamos analisando que ainda éramos demandados muito pouco pela maioria das equipes SF. Esse diagnóstico acabou desencadeando uma série de discussões internas na equipe NASF, que então decidiu elaborar um questionário, para avaliar o olhar que os trabalhadores das equipes SF tinham do trabalho desenvolvido pelo NASF.
Quadro 1 Questionário de Avaliação do NASF

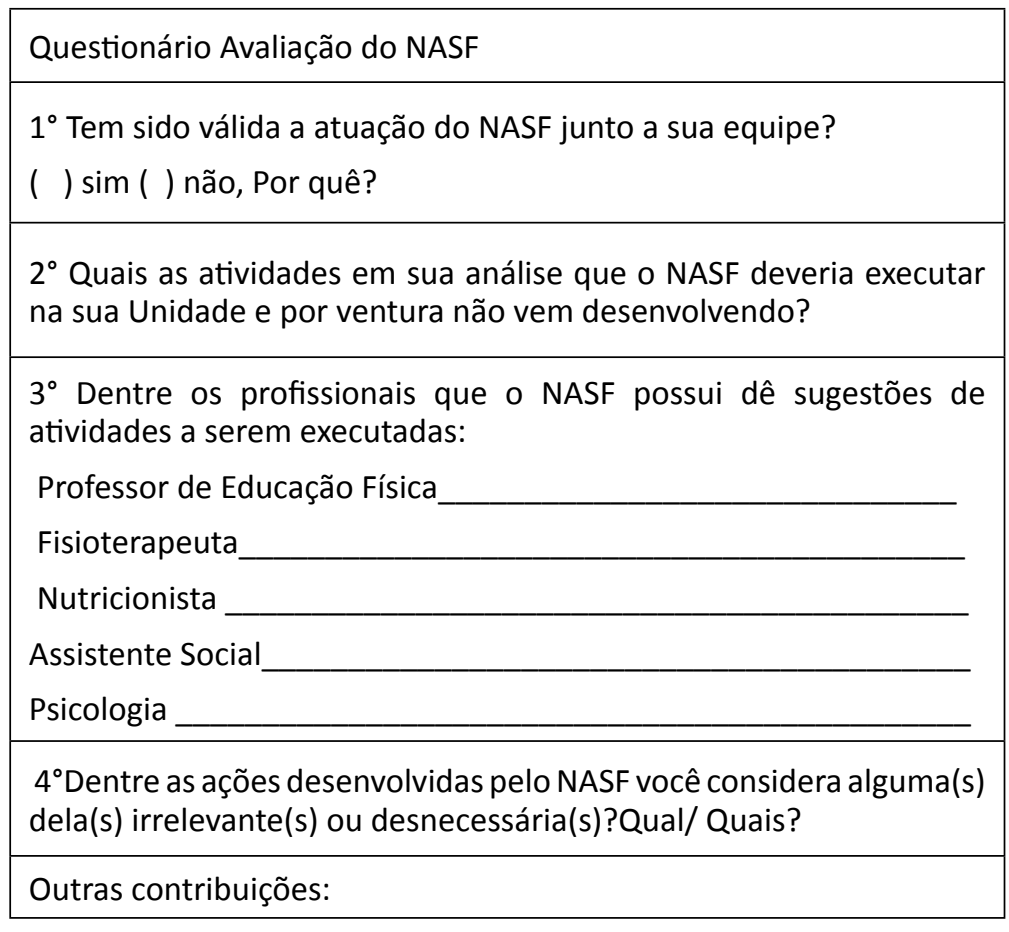

FONTE: Equipe NASF

As respostas foram bastante esclarecedoras. Quando perguntávamos se tem sido válida a atuação do NASF junto a sua equipe, a maioria das respostas era negativa e quanto ao motivo, sinalizavam que não entendiam o objetivo do NASF. Na questão dois, traziam como resposta aquelas atividades mais voltadas aos atendimentos diretos com foco na psicologia, práticas corporais, e cuidador cuidando de quem cuida, mas de modo geral foi a questão menos respondida. A questão três também se dirigia ao aumento do apoio assistencial direto. A questão quatro apontava como grande avanço o Projeto "Cuidando do Cuidador", e chamava a atenção para a crítica às ações desenvolvidas 
pelo NASF, com objetivo mais centrado na mudança do modelo de atenção das equipes, especialmente quando abordávamos conteúdos nas reuniões que tencionavam "o fazer" das equipes.

$\mathrm{Na}$ oportunidade, avaliamos que existia uma diferenciação no nível das ofertas da equipe NASF no tocante a Núcleo ${ }^{9}$ e Campo $^{10}$ (CAMPOS, 2006). Estávamos exercendo muito bem as ações do Campo, mas alguns Núcleos de saber apareciam pouco, apesar de todos desenvolverem atividades relacionadas aos saberes "específicos" de cada profissão (práticas corporais, fisioterapia, psicologia, nutrição). Identificamos assim que estas ações de Núcleo precisavam estar mais claras e presentes no cardápio de ofertas das equipes SF, objetivando inclusive melhorar a visão sobre o trabalho do NASF.

A análise das questões levantadas possibilitou-nos a identificação de que os trabalhadores da equipe SF tinham um conhecimento reduzido quanto aos objetos do "saber/ fazer" de cada Núcleo, o que se expressava também no baixo número de contribuições a novas propostas a serem executadas por estes Núcleos nas Unidades durante a aplicação do questionário. Esse fato, por sua vez, dificultou a solicitação de atividades pelas próprias equipes SF no dia a dia.

As várias críticas, pudemos concluir, que estavam ligadas ao desconforto natural, provocado pela tensão/ resistência a mudanças de posturas e de modelo de atenção, necessárias à própria implementação das ações

\footnotetext{
${ }^{9}$ Núcleo: mais estreito, o quê cada um $\neg$ somente ele $\neg$ sabe fazer? (médico- receitas, enfermeira - curativos). Os limites desses dois conceitos são situacionais (depende do que se produz, e da composição da equipe, etc.) Fazem parte de uma metodologia de apropriação e intervenção. (CAMPOS, 2006)

${ }^{10}$ Campo: delimitado pela produção de valores de uso o que se produz, para quê serve? Saúde, educação, etc. (CAMPOS, 2006)
}

do NASF, uma vez que o perfil de cuidado centrado na simples medicalização das queixas, nos procedimentos, nos aspectos biológicos e nas ferramentas duras, configuravamse como principal entrave aos objetivos de ampliação da clínica, matriciamento e cuidado compartilhado, elementos centrais ao trabalho do NASF. Portanto, existindo uma grande necessidade de mudança de trajetória e ao mesmo tempo de reafirmação de posturas e objetivos, daí que o nosso passo seguinte foi a elaboração de um conjunto de propostas de ações dos "Núcleos de saber" a serem acrescidas às ofertas já realizadas às equipes SF.

Quadro 2- Proposta de ações por "Núcleo de saber/ fazer"

\begin{tabular}{|c|l|}
\hline \multicolumn{2}{|c|}{ Proposta de ações por "Núcleo de saber/fazer" } \\
\hline \multicolumn{1}{|c|}{ fazer" } & \multicolumn{1}{|c|}{ Atividades } \\
\hline Reabilitação/ & $\begin{array}{l}\text { Visitas de orientação aos pacientes } \\
\text { acamados e aos seus cuidadores que } \\
\text { não estavam sendo acompanhados pela } \\
\text { fisioterapeuta da Unidade; }\end{array}$ \\
$\begin{array}{l}\text { Avaliaçãocom crianças queapresentassem } \\
\text { suspeita de atraso motor, alterações } \\
\text { posturais por meio de interconsultas e } \\
\text { visitas domiciliares; } \\
\text { Participação em "salas de espera" que } \\
\text { envolvesse problemas respiratórios e } \\
\text { outros temas relacionados à fisioterapia. }\end{array}$ \\
\hline Alimentação e Nutrição & $\begin{array}{l}\text { Encontro com mães/pais ou responsáveis } \\
\text { para orientação da introdução de novos } \\
\text { alimentos ao bebê em "sala de espera", } \\
\text { grupos etc; } \\
\text { Suporte para manutenção de grupo sobre } \\
\text { alimentação saudável nos diversos ciclos } \\
\text { de vida; } \\
\text { Interconsulta com pacientes com suspeita } \\
\text { de sobrepeso, obesidade ou baixo peso, e } \\
\text { hipertensos e diabéticos com dificuldades } \\
\text { de seguir dieta. }\end{array}$ \\
\hline
\end{tabular}




\begin{tabular}{|c|c|}
\hline $\begin{array}{l}\text { Saúde Mental/ } \\
\text { Psicologia }\end{array}$ & $\begin{array}{l}\text { Intervenções em casos que envolvam } \\
\text { sofrimento de toda e qualquer doença, } \\
\text { assim como transtorno mental e uso } \\
\text { abusivo de álcool e outras drogas; } \\
\text { Promoverações que evitemasinternações } \\
\text { em hospitais psiquiátricos, e dessa forma } \\
\text { realizar grupos nas Unidades da Saúde e } \\
\text { outros espaços na comunidade; } \\
\text { Realização de atendimentos clínicos } \\
\text { (interconsultas, para atendimentos } \\
\text { domiciliares) evitar o } \\
\text { encaminhamento para consulta com } \\
\text { psicóloga na rede. }\end{array}$ \\
\hline $\begin{array}{l}\text { Serviço Social/ } \\
\text { Assistente Social }\end{array}$ & $\begin{array}{l}\text { Orientação familiar sobre benefícios a } \\
\text { pacientes com dependência funcional e/ } \\
\text { ou transtornos mentais (atendimentos } \\
\text { domiciliares e interconsultas); } \\
\text { Orientação a famílias com vulnerabilidade } \\
\text { e risco social (atendimentos domiciliares } \\
\text { e interconcultas); } \\
\text { Orientações sobre direitos do cidadão. }\end{array}$ \\
\hline Práticas Corporais & $\begin{array}{l}\text { Interconsultas e atendimentos } \\
\text { domiciliares a pessoas com qualquer } \\
\text { idade com suspeita de sobrepeso, } \\
\text { obesidade, anorexia e bulimia; } \\
\text { Participação em "salas de espera" que } \\
\text { envolvesse problemas relacionados com } \\
\text { o corpo, sexo e sexualidade e outros } \\
\text { temas relacionados a práticas corporais; } \\
\text { Realização de atividades de práticas } \\
\text { corporais em grupos comunitários; } \\
\text { Ações de incentivo a implantação de } \\
\text { espaços comunitários de esporte e lazer. }\end{array}$ \\
\hline
\end{tabular}

A discussão da possibilidade de Apoio, a ser ofertada por cada Núcleo profissional, gerou um documento de apresentação das propostas e uma série de visitas para apreciação dos resultados do questionário e dos direcionamentos adotados. Esse momento foi muito rico porque foi possível aprofundar questões centrais da relação de forma tranquila e clara com cada uma das equipes.

\section{Considerações finais}

A partir das análises realizadas, entendo que a atividade do NASF incorpora ao mesmo tempo o apoio assistencial direto, a troca de saberes em ações conjuntas, as ações de Apoio Institucional (ações de Educação Permanente com foco no "campo do saber/fazer" e na cogestão da clínica).

As ações de Educação Permanente se justificam pela não caracterização das equipes de Saúde da Família enquanto equipe integração ${ }^{11}$, não incorporação das diretrizes da equipe SF em seu cotidiano, e a ausência de um acompanhamento efetivo, por parte dos Coordenadores de Atenção Básica, orientado pelo incentivo à autonomia dos sujeitos, autoanálise e modificação da trajetória.

Dessa maneira, as ações de Educação Permanente passam a ser uma necessidade do processo de trabalho das equipes NASF (discussão de diferentes modelos de agendas de equipe, problematização do conceito e diferenciação entre promoção da saúde e prevenção de doenças e

11 Identificada dentre outros elementos pelo estabelecimento de um projeto assistencial comum, flexibilidade na divisão do trabalho, autonomia técnica de caráter interdependente, eficácia na comunicação intrínseca ao trabalho. (PEDUZZI, 2001) 
da importância da incorporação dessas atividades ao processo de trabalho da equipe, reflexão quanto a lógica do Acolhimento), já que as Coordenações de Atenção Básica até o momento não têm dado conta desta demanda. $E$, se a equipe de Saúde da Família não funciona conforme os princípios da Estratégia de Saúde da Família, claro está que o Apoio ofertado pelo NASF fica extremamente deficitário.

Entretanto, a modalidade de Apoio Institucional deve se estabelecer com base em cada território, utilizando como análise as características de cada município, as diferentes necessidades das equipes e da comunidade. Resta então a questão: em que escala cada uma das modalidades de Apoio aparece no "fazer" do NASF?

À análise desta experiência e dos objetivos centrais das políticas de Atenção à Saúde, destaco dentre as modalidades de Apoio da equipe NASF, o investimento em ações de Apoio Matricial que estabeleçam através do tempo a troca de saberes de ações clínicas coletivas, contribuindo duplamente para a melhoria da saúde da população, e mudança do modelo de atenção das equipes por meio da ampliação da clínica, e, do estabelecimento da lógica da cogestão, e avaliação constante das ações.

Para tanto, é de suma importância que cada "Núcleo profissional" dê sua contribuição à oferta de saberes, práticas e/ou competências, ampliando a capacidade clínica de diagnóstico, tratamento e de promoção da saúde da comunidade.

Assim, é importante considerar que apesar da prioridade sinalizada às ações de cunho coletivo, isto é, realizadas junto com a equipe de Saúde da Família, o processo de trabalho do NASF pode/deve contemplar ações de Educação Permanente individuais com os profissionais da Unidade e o desenvolvimento de ações clínicas diretas com os usuários, de modo a garantir o atendimento dos casos prioritários e de demandas reprimidas pelo próprio sistema da Média Complexidade, e, a facilitar o diálogo com as equipes mínimas.

Por conseguinte, defendo que o processo de trabalho do NASF se dê com uma ampla oferta de ações, mas que priorize a mudança do modelo de atenção em saúde com a ampliação da clínica, o incentivo à autoavaliação e a incorporação por parte da equipe das ações de promoção da saúde e prevenção das enfermidades com uso de tecnologias leves e leve-duras.

A experiência ora narrada durou cerca de um ano e meio. Este caminhar no NASF com a proposta de aumentar a resolutividade das ações da Estratégia de Saúde da Família, com foco no Apoio Matricial, gerou um imenso aprendizado e amadurecimento pessoal e profissional, devido aos grandes desafios encontrados no decorrer.

Alguns destes desafios foram superados, e outros possibilitaram rever o meu modo de agir e de pensar, sendo as principais mudanças a percepção da necessidade de construir conjuntamente o entendimento de Apoio, de oferecer uma escuta mais sensível quanto às reais necessidades das equipes SF (muitas vezes construíamos em conjunto as ações a serem realizadas mas sem grande valorização do momento e das expectativas das equipes SF) e de compreender a importância do equilíbrio entre "Campo" e "Núcleo" nas ações do NASF ampliando ofertas às equipes SF. 


\section{Referências}

BRASIL. Ministério da Saúde. Clinica ampliada, equipe de referência e projeto terapêutico singular. Brasília, 2008.

Caderno de Atenção Básica; diretrizes do NASF: Núcleo de Apoio a Saúde da Família. Brasília, 2009a.

. Gestão participativa e Cogestão. Brasília. 2009b.

CAMPOS, G. W. S. Clínica e saúde coletiva compartilhadas: teoria Paidéia e reformulação ampliada do trabalho em saúde. In: CAMPOS, G. W. S. et al. (Orgs.). Tratado de Saúde Coletiva. Rio de Janeiro: Fiocruz, 2006.

MERHY, E. E. A perda da dimensão cuidadora na produção da saúde - Uma discussão do modelo assistencial e da intervenção no seu modo de trabalhar a assistência. In: CAMPOS, C. R.; et al. Sistema Único de Saúde em Belo Horizonte - reescrevendo o público. Belo Horizonte: Xamã/ VM Ed., 1998. p. 103-120. Hucitec, 2002.

Saúde: a Cartografia do Trabalho Vivo. São Paulo:

MERHY, E.E. et al. Em busca de Ferramentas Analisadoras das Tecnologias em Saúde: A Informação e o dia-a-dia de um Serviço, Interrogando e Gerindo Trabalho em Saúde. In:

MERHY, E. E.; ONOCKO, R. (org.). Agir em Saúde; um desafio para o público. São Paulo: Hucitec, 1997.

OLIVEIRA, Gustavo N. Devir apoiador: uma cartografia da função apoio. 2011.175f. Tese (Doutorado em Saúde Coletiva) Faculdade de Ciências Médicas, UNICAMP, Campinas, 2011.

PEDUZZI, Marina. Equipe multiprofissional de saúde: conceito e tipologia. Revista de Saúde Pública, São Paulo, v.35, n.1, Feb.2001, p.103-109. Disponível em <http:// www.scielosp.org/scielo.php?script=sci_arttext\&pid=S0 $0349102001000100016 \&$ Ing=en \&nrm=iso $>$. Acesso em 12 de junho de 2014.http://dx.doi.org/10.1590/S003489102001000100016. 


\title{
A Vivência de Apoio Institucional na 7ạ Diretoria Regional de Saúde
}

\author{
Karísia Macêdo Batista
}

\section{O início de tudo...}

Minha experiência com o Apoio Institucional iniciou-se em 2007, a partir de uma ação da Diretoria da Atenção Básica da Secretaria da Saúde do Estado da Bahia (DAB/SESAB) ${ }^{1}$, proposta numa oficina realizada entre técnicos da $D A B$, 7a..Diretoria Regional de Saúde (7a. DIRES/SESAB) e gestores da saúde dos municípios da região. Nesta oficina a Diretoria de Atenção Básica propôs uma mudança organizacional do processo de trabalho entre esses três atores, na lógica do Apoio Institucional, fundamentado no fortalecimento de vínculos, longitudinalidade, proximidade, apoio e Educação Permanente, a fim de possibilitar a Gestão Estadual espaço para o diálogo, pactuação, apoio e enfrentamento concreto dos desafios vividos pelos municípios no desenvolvimento da Atenção Básica.

${ }^{1}$ A Diretoria de Atenção Básica compõe o organograma estrutural e funcional da Superintendência de Atenção Integral à Saúde (SAIS) da Secretaria da Saúde do Estado da Bahia. 
Por se tratar de uma estratégia que vem sendo realizada desde 2007 pelos técnicos desta DIRES, tanto como apoiados quanto como Apoiadores, este texto tem como objetivos relatar a vivência do Apoio Institucional na DIRES no período de 2007 a 2010, identificando as ações e estratégias que vinham sendo realizadas, as dificuldades e facilidades para sua operacionalização, bem como avaliações acerca da efetividade desse arranjo para a rede de saúde e sugestões para continuidade do processo.

Este arranjo de gestão possibilita análise da situação de saúde de um determinado município ou da organização do processo de trabalho e das práticas de saúde das equipes de Atenção Básica, identificando, mediante "rodas" de discussão, os problemas, negociando prioridades e elaborando uma proposta de intervenção, entendendo que todos podem contribuir com o processo de mudança. Utiliza como estratégia construção de "Plano de Ação" e "Carta de Compromissos" para desenvolvimento do Apoio, avaliação e acompanhamento do processo pelos diversos atores representantes do município (gestores, trabalhadores e usuários), equipe da Atenção Básica da DIRES (Apoiadores Institucionais) e equipe de referência da DAB (Apoiadores Institucionais).

Outra estratégia para melhor qualificar o processo de trabalho e ajudar na efetivação das ações de Apoio Institucional, surgiu na oportunidade de participar do Curso de Especialização em Saúde da Família e Gestão da Atenção Básica, ambos com ênfase na Implantação de Linhas do Cuidado, realizado pela DAB em 2008, em parceria com a Escola Estadual de Saúde Pública (EESP). Esse curso contava com a participação de trabalhadores da Estratégia de Saúde da Família e de gestores dos municípios sede de Região de Saúde. Participei enquanto representante da DIRES. Durante as discussões foram abordados diversos temas e, uma das estratégias propostas e discutidas para potencializar as práticas de gestão foi o Apoio Institucional, tanto dos gestores para as equipes de Saúde da Família, quanto da gestão, nas diferentes instâncias governamentais, a exemplo do Apoio Institucional da DIRES aos municípios de sua área de abrangência administrativa.

Durante o curso, o Apoio Institucional da DIRES ao Município sede da Região de Saúde e sede do Núcleo Microrregional de Educação Permanente ${ }^{2}$ foi significativo, principalmente na sensibilização e seleção dos profissionais odontólogos, enfermeiros e médicos das Equipes de Saúde da Família do Município, que participariam como educandos do curso.

Todavia, ao longo do curso, houve desistência dos profissionais da gestão municipal e minha participação enquanto Apoiadora ficou prejudicada, por fatores tais como: pouca governabilidade dos técnicos para efetivação de algumas propostas; ausência dos gestores/educandos nas discussões realizadas nos momentos presenciais; saída dos gestores da equipe de gestão da Diretoria da Atenção Básica do município e, por fim, falta de apoio da nova equipe aos profissionais e nas discussões levantadas nos momentos presenciais, tanto relacionadas à estruturação das redes de serviços existentes na perspectiva da Linha de Cuidado em questão, quanto no processo de trabalho dentro das equipes de Saúde da Família. Vale a pena ressaltar que um dos pontos estimulados durante o curso, discutido e proposto, inclusive pelos profissionais (educandos) foi a necessidade de Apoio Institucional da equipe de gestão às equipes de Saúde da Família, porém até o encerramento do curso essa proposta não se efetivou.

${ }^{2}$ O Núcleo Microrregional de Educação Permanente constitui-se num grupo de trabalhadores e gestores do município sede da Região de Saúde, e foi planejado para fomentar e desenvolver processos regionais de Educação Permanente para a Atenção Básica (Nota do autor). 
Como "herança" do curso surgiu a necessidade de que eu assumisse a referência para as ações de Educação Permanente na 7ạ. DIRES. Dessa forma, apoiei os gestores dos municípios da Região de Saúde nas discussões para elaboração da proposta de descentralização das ações do Núcleo Microrregional de Educação Permanente, por meio da realização do Acolhimento Pedagógico (nova proposta da DAB para o antigo curso introdutório para Equipes de Saúde da Família) ocorridas dentro do Colegiado de Gestão Microrregional de Saúde.

Apesar das dificuldades sinalizadas, o Apoio Institucional tem se efetivado como uma forte estratégia no suporte para a reorganização da Atenção Básica da Regional de Saúde nos municípios de sua área de abrangência administrativa e fortalecimento de práticas transformadoras no âmbito da saúde da população, estimulando a corresponsabilidade, busca de parcerias e unificação de esforços entre os diferentes atores sociais.

\section{Entre as facilidades e dificuldades, o Apoio segue}

\section{existindo...}

Na busca para mudança de modelo de práticas de saúde voltadas para esse complexo processo saúde-doença e sua relação com o cuidado envolvendo trabalhadores, usuários e gestores, o Apoio Institucional contribui na relação entre DIRES e municípios, consolidando parcerias e corresponsabilidades enquanto instituição que supervisiona, planeja, regula, avalia e oferece assistência técnica para efetividade do Sistema Único de Saúde no âmbito municipal, particularmente na Atenção Básica. Isso foi observado numa pesquisa acerca da percepção de alguns gestores dos municípios da região, realizada em 2009:

Foi constatado inferências a mudança na relação DIRES/ MUNICÍPIO, como uma relação onde já há percepção de um processo de trabalho conjunto, harmonioso na busca de soluções, no comportamento dos profissionais, coordenadores e usuários, tendo como resultado mais interesse, mais disciplina para resolução das questões de saúde, mais humanização no atendimento, tudo isso em decorrência da ação do Apoio Institucional. Ainda ressalta-se que a presença dos profissionais da DIRES no município, estimula melhoria na qualidade da administração representando apoio no atendimento às necessidades, no estreitamento de laços, criando vínculos, deixando de ter papel exclusivo de fiscalização como anteriormente acontecia (COELHO; JESUS; SANTOS, 2009, p.25).

Mesmo considerando a relevância do Apoio Institucional da 7a. DIRES aos municípios, é necessário apontar algumas dificuldades para sua operacionalização; uma delas, identificada em minha vivência, foi a dificuldade de acompanhamento efetivo dos "Planos de Ação" elaborados a partir dos problemas identificados. É necessário o planejamento de ações viáveis, que possibilitem seu cumprimento, a fim de que os planos produzidos nessas visitas não sejam simplesmente arquivados como tantos instrumentos de gestão que "não saem do papel", elaborados apenas por exigências ou por ocasião de sanções financeiras aos municípios. Outra dificuldade é a necessidade de priorização das visitas de acompanhamento em detrimento de algumas demandas existentes na Regional, objetivando dessa forma, o acompanhamento efetivo das ações planejadas pelos municípios. 
Por fim, cabe salientar alguns incômodos sentidos pelos Apoiadores neste processo como o fato de que, apesar da identificação dos problemas e a realização do planejamento conjunto de ações durante as visitas, muitos acordos firmados não foram cumpridos pelos gestores municipais, sobretudo aqueles relacionados ao aporte de recursos financeiros, como adequação de estrutura física das Unidades de Saúde e aquisição de materiais e equipamentos, e, mesmo mediante a emissão de relatórios aos setores responsáveis, nenhuma ou poucas sanções foram aplicadas a esses gestores e municípios, comprometendo assim a credibilidade da ação dos técnicos.

Acredito que um dos motivos para alguns desses acordos pactuados durante as visitas de Apoio não serem cumpridos, deva-se à ausência de autonomia financeira por parte da maioria dos secretários municipais de saúde, e, quando identificada tal dificuldade tentou-se negociar a presença dos prefeitos nas reuniões, visando assegurar o adequado financiamento dos acordos firmados. Contudo, cabe ressaltar, que nem todos são acessíveis e/ou interessados em discussão de problemas e proposição de mudanças. Apesar disso, temos conseguido alguns avanços, o que motiva a continuar investindo na estratégia Apoio Institucional.

Importantes exemplos desses avanços foram: as mudanças verificadas no processo de trabalho das equipes, como alguns rearranjos simples dentro da estrutura existente, que têm possibilitado a melhoria do acesso dos usuários a alguns serviços já ofertados; reflexões e mudanças no processo de trabalho de algumas equipes de Saúde da Família e fortalecimento do controle social; sem falar no processo de Educação Permanente, inerente às ações de Apoio institucional, pois, muitas vezes um olhar externo, ou seja, um olhar de alguém que está fora do problema, faz com que os profissionais desses municípios passem a enxergar soluções viáveis, até então não visualizadas.

Dentro desse contexto, a presença de um agente externo às equipes, tanto de Saúde da Família quanto de gestão, tem como principal função facilitar a construção de espaços de escuta, onde os objetivos institucionais possam ser debatidos e articulados com os saberes e interesses dos trabalhadores e usuários. Além disso, algumas experiências exitosas alcançadas por alguns municípios podem ser compartilhadas com os demais, possibilitando a transformação de algumas situações e comportamentos negativos como aqueles anteriormente citados.

Finalmente, fica evidenciado que a gestão da saúde na instância municipal necessita de suporte e apoio logístico dos níveis central e regional para desenvolver suas ações e gerir os serviços locais de saúde, bem como de acompanhamento, avaliação e controle, realizados num contexto de maior abertura para o estabelecimento de inter-relações importantes no processo de trabalho, e o Apoio Institucional vem proporcionar tudo isso, vez que, muitos técnicos dos municípios relatam que o Apoio Institucional realizado pela 7ạ. DIRES tem servido como agente de motivação para eles.

Apesar das dificuldades e facilidades relatadas, - Apoio Institucional tem conseguido proporcionar o fortalecimento de vínculos, longitudinalidade, proximidade e Educação Permanente, que se efetiva como uma importante estratégia contribuindo para a reorganização da Atenção Básica nos municípios, tanto que, após sua implementação, a 7ạ. DIRES deixou de ser referência como instituição exclusivamente fiscalizadora e passou a ser vista como parceira no desenvolvimento das ações de saúde, na orientação sobre as demandas e priorização dos programas, em atendimento às diretrizes do Sistema Único de Saúde. 


\section{Referências}

COELHO, M. L. A; JESUS, L. M. M.D; SANTOS, T. O. Análise da percepção da gestão municipal frente à necessidade da realização do Apoio Institucional como estratégia norteadora para reorganização da Atenção Básica, em municípios da 7ạ DIRES, no ano de 2008. Salvador: Escola Estadual de Saúde Pública, 2009. Trabalho de Conclusão de Curso.

\section{Parte II}

\section{O Apoio Institucional no Território}




\section{Apoio Institucional à Gestão Municipal de Saúde para implantação do Acolhimento}

Viviane Mascarenhas Gois Prado, Alessandra Martins dos Reis

Este relato apresenta a experiência de Apoio Institucional para implantação do Acolhimento (BRASIL. Ministério da Saúde. Secretaria de Atenção à Saúde. Departamento de Atenção Básica, 2011, p.19) ${ }^{1}$ nas Equipes de Saúde da Família de um Município da Região Metropolitana de Salvador, durante o ano de 2008.

A inserção da primeira autora deste relato como Coordenadora da Vigilância Epidemiológica municipal propiciou o desenvolvimento de uma intervenção junto com o núcleo de coordenadores da Secretaria Municipal de Saúde e Equipes de Saúde da Família do Município. Ao iniciar a Especialização em Saúde da Família com ênfase na

${ }^{1}$ Acolhimento é uma prática presente em todas as relações de cuidado, nos encontros reais entre trabalhadores de saúde e usuários, nos atos de receber e escutar as pessoas, podendo acontecer de formas variadas ("há acolhimentos e acolhimentos"). O Acolhimento pode ser um mecanismo de ampliação ou facilitação do acesso aos serviços de saúde; pode ser postura, atitude e tecnologia de cuidado; ou ainda um dispositivo de reorganização do processo de trabalho da equipe de saúde. (BRASIL. Ministério da Saúde. Secretaria de Atenção à Saúde. Departamento de Atenção Básica, 2011, p.19). 
coordenação e gerenciamento de processos de trabalho, promovida pela Secretaria da Saúde do Estado da Bahia (SESAB), essa autora teve a oportunidade de participar de espaços de Educação Permanente sobre temas relacionados ao Apoio Institucional e qualificação do processo de trabalho na Atenção Básica, com intensa troca de experiências.

A inserção da segunda autora deste relato como tutora do curso de Especialização e Apoiadora Institucional da Diretoria de Atenção Básica da SESAB (DAB/SAIS/SESAB) ${ }^{2}$ propiciou uma intervenção junto com a Gestão municipal naquele território. Avisita da Apoiadora resultou na avaliação das necessidades de intervenção na Atenção Básica e na prática dos temas discutidos durante o curso, dentre eles - Acolhimento como dispositivo de mudança das práticas e Apoio Institucional, além de acompanhar o processo de mudança orientando e apoiando as intervenções a partir da construção de um "Plano de Ação".

Em 2008, o núcleo da Secretaria Municipal de Saúde, composto pelas coordenações de Atenção Básica, Saúde Bucal, Vigilância Epidemiológica, Vigilância Sanitária e Promoção à Saúde, atuava de modo integrado, fato que contribuiu para avaliação dos serviços e o início da vivência como Apoiadores Institucionais municipais.

O curso de Especialização e as visitas ao Município dos Apoiadores Institucionais da DAB/SESAB e da 1a Diretoria Regional de Saúde da SESAB (DIRES/SESAB) estimularamno à implantação da lógica do Apoio Institucional e à construção de uma agenda de atividades e de intervenções na perspectiva do aprimoramento do processo de trabalho da equipe de Gestão municipal e das equipes de Saúde da Família.

\footnotetext{
${ }^{2}$ A Diretoria de Atenção Básica compõe o organograma estrutural e funcional da Superintendência de Atenção Integral à Saúde (SAIS) da Secretaria da Saúde do Estado da Bahia.
}

Um dos pontos pactuados entre Apoiadores da SESAB e Gestão Municipal foi a construção de uma agenda municipal de Apoio Institucional às equipes de Saúde da Família, com aprimoramento das boas práticas já existentes.

Ao intensificar o acompanhamento cotidiano das equipes de Saúde da Família na lógica do Apoio, a equipe de Gestão Municipal observou que, apesar da presença de estrutura física adequada, profissionais e gestores comprometidos, havia dificuldades na implantação de mudanças no processo de trabalho das equipes. A população mostrava resistência a mudanças, pois se tratava de usuários habituados a um modelo centrado em ações curativas e respostas imediatas. Os usuários se diziam insatisfeitos com os atendimentos nas Unidades de Saúde, e resistentes a participar das ações de promoção à saúde. Além disso, a alta rotatividade de trabalhadores na Estratégia Saúde da Família gerava a necessidade de atualizações frequentes dos novos profissionais.

Após análise da Estratégia Saúde da Família no Município utilizando avaliação de indicadores, o levantamento dos principais entraves para o funcionamento adequado e a avaliação da satisfação dos usuários, foram realizadas algumas reuniões com equipe da Secretaria Municipal de Saúde e Apoiadores Institucionais da DAB/ SESAB, para planejamento das ações e acompanhamento do "Plano de Ação". Esses espaços de reflexão permitiram a conclusão de que era necessário estruturar o Acolhimento aos usuários para reorganizar o processo de trabalho das equipes.

Uma vez iniciada a implantação do Acolhimento nas cinco equipes de Saúde da Família do Município, esperávamos a reorientação do processo de trabalho nas Unidades de Saúde. Com essa reorientação pretendíamos ampliar e melhorar a qualidade do acesso da população 
e melhorar a comunicação entre gestão e trabalhadores permitindo aos gestores conhecer as perspectivas desses profissionais em relação à Estratégia de Saúde da Família, seus estímulos, entraves e contribuições para melhoria do processo de trabalho.

Acolher é uma maneira de estreitar o elo entre profissionais de saúde e usuários, tornando o olhar do profissional centrado nas necessidades do usuário. Além disso, permite uma reflexão sobre o processo de trabalho e traz responsabilização e maior resolubilidade. 0 Acolhimento funciona como um dispositivo que interroga processos intercessores que constroem as "relações clínicas" das práticas de saúde, além de expor e as relações de acessibilidade aos serviços de saúde (FRANCO; BUENO; MERHY, 1999).

A proposta é inverter a lógica de organização e funcionamento do serviço de saúde, promover a cidadania, envolver toda a equipe e aproximar os trabalhadores dos usuários e da gestão. Neste contexto, os trabalhadores de saúde também se sentem acolhidos, porque se espera um envolvimento de todos da rede de serviços, proporcionando melhor resolubilidade e melhorando a estrutura do serviço, estimulando o exercício da referência e contra referência, desenvolvendo habilidades pessoais, satisfação do usuário, organização do serviço, redução ou fim da demanda reprimida.

O desafio de alguns anos é construir processos de intervenções institucionais em diferentes estabelecimentos de saúde, tomando como referência o interesse do usuário, construindo processos de mudança ao implantar Acolhimento e melhorar o acesso dos usuários aos serviços de saúde (MEHRY, 1997).

O Acolhimento pode ser entendido em três dimensões ou sentidos: (1) como mecanismo de ampliação do acesso, ou seja, atender a todas as pessoas que procuram os serviços de saúde, garantindo a acessibilidade universal; (2) como postura, atitude e tecnologia de cuidado, que envolve a qualificação da relação estabelecida entre trabalhador de saúde e usuário de maneira mais solidária e humanitária; (3) como dispositivo de reorganização do processo de trabalho, transferindo o foco do atendimento do médico para a equipe multiprofissional de Acolhimento, que se compromete a escutar de forma qualificada os usuários e, dar encaminhamentos necessários e resolutivos (BRASIL. Ministério da Saúde. Secretaria de Atenção à Saúde. Departamento de Atenção Básica, 2011).

\section{O Município como cenário da experiência de Apoio}

Município situado ao norte da Baía de Todos os Santos no litoral da Bahia. Possui uma área de aproximadamente 11 $\mathrm{Km}^{2}$. Em 2007, possuía população de $15.432^{3}$ pessoas, com moradores nascidos no Município e trabalhadores levados pelas empreiteiras que atuam no complexo petrolífero, que por vezes terminavam fixando residência.

O Município apresentou grande crescimento nos últimos anos, principalmente pela imigração não apenas pelo fluxo do trabalho, como também pela atração por melhores condições conquistadas pelos moradores após emancipação. É importante salientar que por estar localizado na região litorânea do Estado da Bahia, no período de dezembro a fevereiro, tem a característica de aumento da população municipal devido ao grande número de veranistas e turistas que passam temporadas no Município, chegando a aumentar a população em $200 \%$.

${ }^{3}$ (IBGE. 2007) 
No período da experiência, o Município contava com $100 \%$ de cobertura da Estratégia Saúde da Família e, havia 5.154 famílias cadastradas no Sistema de Informação da Atenção Básica $(\mathrm{SIAB})^{4}$, sendo que destas, 139 residiam na zona rural. Contava com dez Unidades Públicas de Saúde Municipais, a saber: cinco Unidades de Saúde da Família (USF), uma Unidade Básica de Saúde (UBS), um Centro de Atenção Fisioterápica, um Centro de Atenção à Saúde Mental, um Centro de Especialidade Médicas e Odontológicas e um Hospital municipal.

\section{Caminho Metodológico}

A proposta foi realizar oficinas com todas as equipes de Saúde da Família do Município, com o propósito de induzir novas práticas nos serviços a partir da interatividade entre estes trabalhadores e gestores municipais, na produção de novos conhecimentos e indução de novas práticas.

\section{Planejamento e preparação para realização das oficinas}

Na primeira visita dos Apoiadores Institucionais da SESAB, foi realizado o reconhecimento dos serviços de saúde da rede municipal com o objetivo de diagnosticar o processo de trabalho desenvolvido por cada equipe, a estrutura física de cada serviço e o perfil dos trabalhadores.

Utilizando a matriz proposta pela Política Estadual da Atenção Básica de 2007 (BAHIA. Secretaria da Saúde. Superintendência de Atenção Integral à Saúde. Diretoria de Atenção Básica. 2007), elaboramos um "Plano de Ação", que constava de problemas identificados e debatidos com

4 DATASUS. 2014 a equipe da Secretaria Municipal de Saúde, avaliação de indicadores, análise crítica de cada situação e intervenções propostas, prazos e responsáveis pelas ações.

A elaboração do "Plano de Ação" foi disparadora das intervenções e induziu reuniões posteriores com a Secretária de Saúde e Coordenadores da Atenção Básica, Saúde Bucal, Vigilância Epidemiológica e Vigilância Sanitária.

Em reuniões semanais os gestores municipais se reuniram para uma revisão literária e discussão sobre como atuar junto às equipes de Saúde da Família implementando - Apoio Institucional municipal. Foi definido que cada Coordenador seria responsável por uma equipe para resolver questões logísticas e estreitar a relação com os profissionais que atuavam na estratégia, com visitas semanais às Unidades, levantamento de problemas, sugestões e oferta de Apoio às demandas dos profissionais.

No segundo encontro entre Apoiadores Institucionais da SESAB e do Município, foi pactuada a utilização do fluxograma descritor como metodologia para aprofundar o diagnóstico sobre o processo de trabalho de cada equipe de Saúde da Família e envolver os trabalhadores na reflexão sobre acesso ao serviço e construção de novas práticas. Foi ofertado um texto à equipe da Secretaria Municipal de Saúde para estudo sobre a experiência da utilização do fluxograma descritor no município de Luz - Estado de Minas Gerais (FRANCO, 2003), com algumas características parecidas com o Município em que atuamos, tais como população e território geográfico.

O fluxograma descritor utiliza uma elipse para indicar a entrada do usuário no serviço de saúde, um retângulo para tomadas de decisão e um losango para as ações dentro do serviço. A partir dessas figuras forma-se o passo a passo do usuário nas Unidades da Saúde da Família, evidenciando o processo de trabalho dos funcionários e 
permitindo o planejamento de intervenções de acordo com o levantamento dos problemas feitos pela própria equipe (FRANCO, 2003).

O fluxograma descritor consiste em uma representação gráfica do processo de trabalho, buscando perceber os caminhos percorridos pelo usuário, quando procura assistência e sua inserção no Serviço. O fluxograma permite um olhar agudo sobre os fluxos existentes no momento da produção da assistência à saúde, e permite a detecção de seus problemas. É como se ao aplicá-lo, lançássemos luz em áreas de sombra até então não percebidas, e que operam no sentido contrário a uma atenção com qualidade, centrado no usuário (FRANCO, 2003, p.4).

No terceiro encontro entre Apoiadores Institucionais municipais e estaduais, a Apoiadora da DAB/SESAB, uma das autoras deste relato, facilitou uma oficina com os Apoiadores municipais com o objetivo de simular a aplicação do fluxograma descritor como preparação para as oficinas que aconteceriam posteriormente com as equipes. Os Apoiadores municipais foram convidados a escolher uma equipe do Município que considerassem ter maior conhecimento sobre seu processo de trabalho e a se colocar no lugar dessa equipe, descrevendo o caminho que um usuário percorre desde a chegada ao serviço até a resolução da situação. A facilitadora fazia perguntas aos participantes e registrava cada passo que o usuário percorria através da representação gráfica proposta por FRANCO (2003) sobre fluxograma descritor.

Ao fim da simulação, a equipe de Apoiadores municipais sentiu maior segurança em realizar as oficinas com as equipes, ao mesmo tempo em que percebeu a importância desta ação para ampliar seu conhecimento sobre a prática de cada equipe de Saúde da Família que apoiavam no Município, podendo qualificar suas intervenções de Apoio Institucional.

Neste terceiro encontro entre Apoiadores foi realizado ainda um planejamento que abordou: estratégias de sensibilização, agendamento das oficinas, proposta de elaboração de protocolo clínico sobre Acolhimento, construção de um fluxograma municipal que sintetizaria as diretrizes de acesso de usuários aos serviços, divulgação na comunidade com lançamento de uma cartilha sobre Acolhimento, fluxograma municipal dos serviços de saúde e orientações sobre o processo de trabalho das equipes de Saúde da Família.

Optou-se pela participação de todos os profissionais das equipes de Saúde da Família. Para tanto, foi necessário fechar cada Unidade de Saúde por um dia, sendo a oficina planejada com antecedência e comunicada à comunidade por meio de cartazes, pelos profissionais e pelos Agentes Comunitários de Saúde (ACS) nos domicílios.

Outros encontros entre Apoiadores foram agendados para análise e acompanhamento do processo, utilizandose também ferramentas de comunicação à distância como telefone e meio eletrônico (e-mail), além dos encontros presenciais.

A experiência de vivenciar a prática do Apoio Institucional proporcionou às autoras intenso aprendizado na gestão da Atenção Básica por se tratar de uma época pioneira de implantação no Estado da Bahia, estávamos descobrindo, juntos, o que significava ser Apoiador nessa dimensão.

Para a autora que vivenciou o planejamento e preparação das oficinas na perspectiva de aprendizado para a prática do Apoio Institucional em âmbito municipal 
a experiência foi relevante, pois pôde atrelar a teoria discutida durante a especialização e a prática vivenciada no seu trabalho. Para a autora que vivenciou o processo como Apoiadora Institucional da DAB/SESAB, os momentos de interação no curso de especialização com gestores municipais e a interação direta no Município foram fundamentais para o aprimoramento das práticas de Educação Permanente desenvolvidas no Apoio.

\section{Construção do fluxograma descritor com as equipes de Saúde da Família}

Durante a construção do fluxograma descritor, os integrantes das equipes de Saúde da Família reconheceram como um importante momento de reflexão sobre a implementação do Acolhimento, pois trazia uma visão de todo o processo de trabalho realizado por cada equipe com discussão do papel de todos os seus integrantes.

As oficinas foram realizadas entre os meses de março a junho do ano de 2008. Participaram todas as categorias profissionais das equipes de Saúde da Família, apoio administrativo, serviços gerais, exceto vigilantes, devido à rotatividade de seus horários.

A cada oficina foram construídos dois fluxogramas: inicialmente um com o processo de trabalho atual da equipe e posteriormente outro como modelo que a equipe achava ser ideal. A princípio, a consolidação das novas propostas de fluxograma de cada equipe, poderia sintetizar uma diretriz do processo de trabalho das equipes no Município. Ao fim de cada oficina foi realizada uma rápida avaliação pelos participantes, e escolhidos dois representantes, um de nível médio, outro de nível superior, para compor um grupo de trabalho junto aos gestores para aprofundamento de propostas de qualificação dos serviços do Município.

\section{Oficina com equipe IV}

A primeira oficina de aplicação do fluxograma descritor foi realizada com a equipe IV, no dia 17 de março do ano de 2008. Esta equipe foi escolhida para iniciar as atividades, pois já realizava Acolhimento, porém centrado na figura do médico, e alguns membros da equipe não sabiam a distinção entre triagem e Acolhimento ${ }^{5}$. A abertura da oficina foi feita pelo Coordenador da Atenção Básica falando sobre fluxograma, sem, no entanto, falar sobre Acolhimento, estratégia esta usada para evitar induzir a equipe.

A construção do fluxograma descritor foi iniciada com a mediação de três Apoiadores Institucionais do Município. Ao ser construída a representação gráfica do processo de trabalho pela equipe, que se mostrou participativa, buscou-se caracterizar que o usuário adentrava na USF e não se dirigia à recepção, pois buscava o profissional mais próximo como um técnico de enfermagem ou um agente

\footnotetext{
${ }^{5} \mathrm{~A}$ triagem tradicionalmente realizada por alguns serviços da Atenção Básica pode ser compreendida como uma classificação dos usuários a partir de suas queixas, gravidade e prioridade para o atendimento médico. O Acolhimento propõe ultrapassar a lógica da queixa e do procedimento e realizar escuta qualificada da demanda, com ampliação das ofertas da equipe para além da consulta médica. Predispõe, portanto, ampliação da capacidade clínica e de cuidado da equipe não apenas para estratificar os riscos (o que é fundamental) ou para realizar intervenções imediatas, mas para organizar-se a partir do acolhimento dos usuários com disponibilidade de um conjunto de ofertas que podem trazer respostas às necessidades de saúde da população. (BRASIL. Ministério da Saúde. Secretaria de Atenção à Saúde. Departamento de Atenção Básica, 2011, p.39).
} 
comunitário de saúde (ACS), e algumas vezes se dirigiam aos consultórios para buscar soluções para atendimento.

Não se formava fila, porém havia distribuição de quatro fichas para falar com a médica. $O$ usuário que não conseguia uma das fichas voltava no outro dia. Essa organização era vista pela equipe como Acolhimento e não como triagem, pois neste momento era visto a necessidade de todos os familiares deste usuário que conseguiu uma das fichas.

Para ter acesso ao cuidado em saúde bucal, um auxiliar de saúde bucal realizava uma triagem; se urgência encaminhava diretamente ao dentista. E não sendo urgência, o usuário era orientado a procurar a Unidade de Saúde, para marcação no dia reservado a sua microárea.

A enfermeira atendia os usuários agendados para ela, alguns daqueles que não conseguiram atendimento médico e pessoas de outros municípios encaminhados pela Coordenação da Atenção Básica.

A equipe percebeu a necessidade de maior envolvimento de todos os profissionais, maior atuação da recepção e reorganização do processo de trabalho. Após a discussão programaram mudanças: a agenda médica passaria a ficar na recepção, que até então ficava em poder da médica que realizava sua própria marcação; todos os dias pela manhã a médica, a enfermeira e o dentista ficariam por um tempo realizando o Acolhimento aos usuários antes das consultas agendadas; pactuou-se que todos eram responsáveis por uma escuta qualificada aos usuários.

Ao término das atividades todos fizeram uma avaliação positiva da oficina com aprovação de novas propostas de trabalho.

\section{Oficina com Equipe III}

A segunda oficina foi realizada em 31 de março do ano de 2008. Utilizou-se a mesma metodologia e a equipe se mostrou participativa e motivada. Após a construção do fluxograma descritor observamos que as ações eram centradas no profissional médico, e que o acesso dos usuários era dificultado pela forma como era feita a marcação de consultas pela recepção. Identificouse que apenas na última semana de cada mês realizava-se marcação de consultas, sendo que os usuários, com receio de não conseguir a vaga, se programavam para agendar no primeiro dia e consequentemente as vagas eram esgotadas rapidamente.

Considerando que o agendamento era realizado para o mês seguinte, ocorria longa espera e grande número de faltas, pois segundo relato dos ACS, os usuários acusavam esquecimento. Esse processo gerava uma demanda reprimida, que se dirigia diretamente ao consultório médico e conseguia atendimento extra.

Após a análise sobre o fluxograma da unidade, a equipe mudou a marcação de consultas que passaria a acontecer diariamente a partir da escuta das necessidades dos usuários, e, pactuou-se que os outros membros da equipe deveriam ser mais participativos. Ao questionarmos sobre quem realizaria o Acolhimento aos usuários, decidiuse que as técnicas de enfermagem junto à recepção ficariam responsáveis. Foi acordada, ainda, a elaboração de um protocolo de atendimento pela equipe de nível superior, para orientar os demais membros da equipe, quanto à avaliação das necessidades clínicas dos usuários. Os ACS se comprometeram a orientar melhor os usuários quanto ao funcionamento das atividades da equipe. Como na primeira oficina, a avaliação também foi positiva. 


\section{Oficina com equipe II}

Em sete de abril do ano de 2008 realizamos a terceira oficina para aplicação do fluxograma descritor com a equipe II. Esta foi uma oficina diferente das demais, pelo fato de haver algumas divergências entre alguns profissionais e resistência por parte de outros para a implantação do Acolhimento.

O fluxograma disposto nos mostrou uma equipe centrada na presença da enfermeira, onde esta tinha sobrecarga de trabalho e os demais profissionais se detinham a atendimentos individuais. Os agentes comunitários de saúde eram pouco participativos, e as técnicas de enfermagem se limitavam ao setor ou procedimentos pelo qual eram responsáveis. A recepcionista, apesar de atender bem os usuários, não exercia sua autonomia. A auxiliar de serviços gerais realizava um bom atendimento aos usuários; sempre atenciosa e resolutiva.

Com a proposta de implantação do Acolhimento, notamos durante a oficina, que esta equipe ainda se apresentava resistente às mudanças. Consequentemente, em alguns momentos os coordenadores direcionaram os tipos de atividades a serem implementadas. Chegamos à conclusão que precisávamos estar mais próximos da equipe, intensificando o Apoio e Educação Permanente, de modo a gerar reflexão e mudança no processo de trabalho.

\section{Oficina com equipe I}

No dia cinco de maio do ano de 2008 , foi realizada oficina com a equipe de Saúde da Família I. Esta equipe se destacava no Município por suas ações inovadoras, com formação de grupos e atividades diferenciadas na comunidade. Esperamos algum tempo para a realização da oficina, pois aguardávamos a chegada de um médico com residência em Saúde da Família para compor a equipe, proporcionando-lhe tempo para conhecer melhor a organização e todo o processo da Unidade de Saúde da Família.

Como já esperado, a oficina foi exitosa e com participação de todos os profissionais, que se envolveram ativamente nas discussões e elaboração do fluxograma descritor. Observamos que havia Acolhimento na Unidade de Saúde, porém os profissionais agiam de forma individualizada, cada um escutava os usuários e tentava resolver os problemas sem muito compartilhamento da equipe. Após construção do fluxograma atuale do fluxograma idealizado pela equipe, considerando a importância daquele momento, os trabalhadores solicitaram uma pausa para realizar uma discussão entre eles e traçarem a melhor forma de implantação do Acolhimento na Unidade.

Nesse momento os Apoiadores ficaram apenas observando a discussão sem muita interferência. A equipe já havia planejado a mudança do processo de trabalho mesmo antes da oficina, valorizando as opiniões de todos os membros, e trabalhando a autonomia de todos os profissionais e a forma de abordagem aos usuários. A equipe fez uma avaliação positiva da oficina de cuja análise se concluiu que trouxe motivação e direcionamento para melhorar seu processo de trabalho. 


\section{Oficina com a equipe $V$}

A oficina com a equipe $V$ foi realizada no dia nove de junho do ano de 2008. Houve contribuições de todos os profissionais que, ao construir o fluxograma descritor, notaram que a maioria dos usuários passava despercebida pela recepção. Um dos pontos que chamou a atenção foi o relato (desabafo) de alguns componentes da equipe que se sentiam angustiados, pois completavam todo o agendamento das consultas, porém os usuários não compareciam no dia agendado, sobrando uma oferta de vagas que eram preenchidas por aqueles usuários que aguardavam as desistências, ou seja, era mais fácil conseguir vagas sem hora marcada (demanda espontânea). Evidenciando-se a falta de planejamento do processo de trabalho, pois as atividades propostas pela equipe não contemplavam o perfil populacional.

No segundo momento da reunião, a equipe elaborou uma nova proposta de fluxograma se comprometendo com o planejamento das ações dentro da Unidade de Saúde e a oferta de serviços com base na necessidade dos usuários. Concordaram com a implantação do Acolhimento aos usuários como uma estratégia importante para a mudança de modelo de atenção à saúde e maior satisfação dos usuários.

\section{Construção do fluxograma descritor do Município}

Após a realização das oficinas com todas as equipes de Saúde da Família do Município e escolha de representantes de cada equipe, foram agendadas reuniões com a proposta de construção de um fluxograma municipal que sintetizasse as principais diretrizes sobre o Acolhimento aos usuários. Esse fluxograma não poderia "engessar" ou padronizar o processo de trabalho das equipes de Saúde da Família, mas servir como uma diretriz com possibilidades de adaptações por cada equipe.

A primeira oficina com o grupo de trabalho foi realizada tomando por base a discussão de textos (FRANCO; BUENO; MERHY, 1999; MERHY, 1997) sobre o Acolhimento, repassados às equipes pela Coordenação da Atenção Básica, para melhor embasamento teórico. No primeiro momento, os participantes foram convidados à revisão dos fluxogramas das cinco equipes construídos nas oficinas anteriores. Essa estratégia levou os trabalhadores a uma reflexão sobre o papel de cada profissional dentro da equipe e a trocar experiências a partir da discussão sobre os fluxogramas construídos, objetivando avaliação da implantação do Acolhimento, e assim foi possível observarmos a sua semelhança, fato este que facilitou a construção do fluxograma municipal.

Os componentes do grupo de trabalho municipal retornaram às Unidades de Saúde e promoveram discussão sobre a proposta junto às equipes. Em uma segunda reunião com cada uma, foi construído um fluxograma municipal que representou os consensos produzidos até aquele momento com as equipes e seus seis representantes.

Ao realizarmos uma avaliação de todo o processo, com os representantes das equipes, podemos concluir que a experiência foi positiva e comprovada com a mudança do 
processo de trabalho, a começar pela maior integração e conceituações de Acolhimento diferenciadas da triagem de usuários. Dentre a compreensão sobre Acolhimento relatada ao finalizar a avaliação pelos trabalhadores podemos destacar: escuta qualificada, ações centradas no usuário, vínculo usuário trabalhador com resolução de problemas, resposta aos problemas enfrentados pelo usuário e atendimento humanizado.

\section{Considerações finais}

A prática do Apoio Institucional promoveu intenso aprendizado a todos os envolvidos: mudanças no processo de trabalho da gestão municipal e de cada equipe de Saúde da Família do Município, aprimoramento do papel do Apoiador Institucional do Estado aos municípios ao servir como experiência piloto para a equipe de Apoio de referência da região e a outros Apoiadores da DAB/SESAB durante $o$ ano de 2008.

O Apoio Institucional da SESAB à equipe de Gestão Municipal induziu a implantação de uma nova lógica de trabalho, na perspectiva de intensificação da presença dos gestores municipais junto às equipes de Saúde da Família, com um olhar diferenciado quanto ao seu papel. Os gestores municipais passaram a reservar maior tempo na agenda para realização de espaços de Educação Permanente com os trabalhadores, ou seja, passaram a apoiar com mais qualidade a reflexão sobre as práticas desenvolvidas e o aprimoramento das ações.

A Educação Permanente foi a prática em destaque nesta experiência: os gestores e trabalhadores colocaram em análise suas práticas cotidianas e, a partir da crítica reflexiva sobre as ações, puderam reconstruir e reinventar seu trabalho.

A experiência de Apoio Institucional à implantação do Acolhimento no Município foi um processo de reestruturação da Atenção Básica. Podemos perceber que promoveu o fortalecimento da rede, a organização do processo de trabalho das equipes, a humanização do atendimento com maior satisfação dos usuários por meio de uma escuta qualificada, a acolhida aos trabalhadores da rede. Ao mesmo tempo os aproximou da gestão, estimulou parcerias e corresponsabilidade da comunidade promovendo melhoria do acesso dos cidadãos aos serviços de saúde.

A reorganização do processo de trabalho das equipes com vistas à ampliação do acesso dos usuários aos serviços e reorganização do agendamento não garante que a escuta seja qualificada suficientemente para tomada de decisões clínicas para atendimento às necessidades dos usuários. É indispensável, portanto, um processo de qualificação dos trabalhadores que realizam o Acolhimento sobre classificação de risco, a partir de cada problema de saúde identificado, e, o estabelecimento de pactos constantes dentro da equipe para aperfeiçoar o tempo de resposta, compartilhamento das responsabilidades e reavaliação permanente da agenda e organização da mesma. Nesse sentido, é o Apoio Institucional a ação capaz de qualificar os trabalhadores e induzir a reorganização constante da equipe de Saúde da Família.

Na perspectiva da autora inserida na Gestão Estadual, podemos considerar que pôde ampliar sua capacidade de Apoio ao testar novas ferramentas, ter a oportunidade de acompanhar com maior proximidade as práticas de gestão e cuidado de um município, aprendendo com a realidade em 
constante análise, desenvolvendo práticas de negociação e pactuação e colocando sua prática em análise no âmbito da sua equipe de Apoiadores Institucionais.

Do ponto de vista da Gestão Municipal, podemos considerar que foi uma primeira aproximação e primeiro passo para a implantação do Apoio Institucional. A constante presença nas Unidades de Saúde da Família, atuando junto às equipes, proporcionou mudanças e avanços com intensificação de atividades de Educação Permanente. A transformação da equipe de gestão em Apoiadores manteve a continuidade da motivação e valorização profissional, promovendo aperfeiçoamento do cuidado à população.

\section{Referências}

BAHIA. Secretaria da Saúde. Superintendência de Atenção Integral à Saúde. Diretoria de Atenção Básica. Política Estadual da Atenção Básica. Salvador: SESAB, 2007.

BRASIL. Ministério da Saúde. Secretaria de Atenção à Saúde. Departamento de Atenção Básica. Acolhimento à demanda espontânea. Brasília: Ministério da Saúde, 2011.

FRANCO, T.B. Fluxograma Descritor e Projetos Terapêuticos em Apoio ao Planejamento: o caso de Luz (MG). In: Merhy, E.E. et al. O Trabalho em Saúde: Olhando e Experienciando o SUS no Cotidiano. São Paulo: Hucitec, 2003. Disponível em: http://www.professores.uff.br/tuliofranco/textos/ fluxograma_descritor_e_projetos_terapeuticos_caso_de_ luz_tulio_franco.pdf. Acesso em: 02 maio 2014.

FRANCO, T.B.; BUENO, W.S.; MERHY, E.E. O acolhimento e os processos de trabalho em saúde: o caso de Betim. Minas Gerais, Brasil. Cadernos de Saúde Pública, Rio de Janeiro, v.2, n.15, p. 345-53, 1999.

IBGE. Censo demográfico: resultados do universo relativos às características da população e dos domicílios da Bahia. Fundação IBGE, 2007.

MERHY, E.E. Em busca do tempo perdido: a micropolítica do trabalho vivo em saúde. In: MERHY, E.E.; ONOCKO, R. (Orgs.) Agir em saúde: um desafio para o público. São Paulo: Hucitec, 1997. 


\title{
Construção de Linha de Cuidado Materno- Infantil: relato de experiência em um muni- cípio baiano
}

\author{
Sílvia Denise Laranjeira Cardoso
}

Dedicado aos participantes do Núcleo Microrregional de Educação Permanente e à Helma Cristiane Cardoso Oliveira (in memória).

A Diretoria da Atenção Básica da Secretaria da Saúde do Estado da Bahia (DAB/SESAB) ${ }^{1}$, em meados de 2009, começou a desenvolver projetos de educação em saúde para atuar junto com a gestão e trabalhadores das equipes de Saúde da Família no Estado. Com o objetivo de provocar mudanças no processo de trabalho na Atenção Básica, e baseado em raras experiências municipais no Brasil, a DAB desenvolveu dois cursos: Especialização em Saúde da Família e Especialização em Gestão da Atenção Básica, ambos com ênfase em implantação de Linhas e Cuidado (PINTO, 2009)2 , nas vinte e oito sedes de Regiões de Saúde

${ }^{1}$ A Diretoria de Atenção Básica compõe o organograma estrutural e funcional da Superintendência de Atenção Integral à Saúde (SAIS) da Secretaria da Saúde do Estado da Bahia.

2 Pinto (2009, p.30), apresenta as "Linhas de Cuidado na perspectiva da necessária programação e articulação entre os diversos serviços do 
no Estado da Bahia. O desenho do curso seguiu a proposta da problematização da realidade vivenciada, permeado pela construção e implantação de Linhas de Cuidado.

Faço partede uma equipe multiprofissional, organizada para desenvolver o Apoio Institucional aos municípios de uma determinada Região de Saúde da Bahia. Neste texto, relatarei minha experiência de Apoio Institucional oferecido a um determinado município da Região de Saúde Centro-Norte, partindo da proposta de implantação da Linha de Cuidado Materno-Infantil, buscando reorganizar a rede de serviços e o fluxo do cuidado no município. Esta proposta estava atrelada e fomentada pelos cursos de Especialização ofertados pela DAB.

Os Cursos de Especialização em Linhas de Cuidado foram uma estratégia para consolidar mudanças na organização e no processo de trabalho das equipes de Saúde da Família e gestores da Atenção Básica. Esta proposta pedagógica buscou a qualificação de trabalhadores e gestores fomentando a capacidade de: refletir criticamente sobre seu fazer e sobre as ações das equipes de Saúde da Família e organização dos serviços de saúde; planejar, organizar, desenvolver e avaliar ações necessárias para implantação das Linhas de Cuidado na Atenção Básica (BAHIA. Secretaria da Saúde. Escola Estadual de Saúde Pública, 2009). Ainda, em relação aos trabalhadores, o curso de Especialização em Saúde da Família buscou a ampliação do fazer clínico na perspectiva da produção de uma atenção integral à saúde.

No fim do ano de 2009, após constantes reuniões internas da DAB, e com as equipes da Escola Estadual de Saúde Pública e reuniões outras com os futuros Orientadores de Aprendizagem de Campo dos cursos,

sistema microrregional, regional e estadual de saúde, com o objetivo de promover um itinerário assistencial que garanta a integralidade do cuidado a um usuário." surgiu a ideia de implantar os Núcleos Microrregionais de Educação Permanente (NR-EP), sendo então implantados nas Regiões de Saúde da Bahia, segundo Plano Diretor de Regionalização do Estado (BAHIA. Comissão Intergestores Bipartite da Bahia, 2012). O NR-EP constitui-se num grupo de trabalhadores e gestores do município sede da Região de Saúde, e foi planejado para fomentar e desenvolver processos regionais de Educação Permanente para trabalhadores e gestores dos municípios, tendo como eixo central a Atenção Básica.

Concomitante à implantação do NR-EP, foi dado início à seleção dos candidatos aos Cursos de Especialização: três médicos, três enfermeiros e quatro odontólogos das equipes de Saúde da Família do Município. Além desses, outros trabalhadores municipais foram convidados, tais como: um coordenador de Atenção Básica, um coordenador de Saúde Bucal, um coordenador médico da Saúde da Família, um coordenador do NR-EP e um técnico da Diretoria Regional de Saúde.

Em maio de 2010, foi dado início às atividades do Núcleo Microrregional de Educação Permanente, em conjunto com as Especializações em Saúde da Família e Gestão da Atenção Básica, com ênfase na Implantação das Linhas de Cuidado.

Os cursos tinham na proposta metodológica encontros presenciais a cada 15 dias. Eu desenvolvia o papel de Orientadora de Aprendizagem de Campo (OAC) dos cursos de especialização e de Apoiadora Institucional da DAB. Assim, costumava desenvolver visitas de Apoio Institucional às Unidades Básicas de Saúde, após a finalização de cada módulo dos cursos ${ }^{3}$, cujos trabalhadores eram educandos do curso de Especialização em Saúde da Família. O objetivo

\footnotetext{
${ }^{3}$ Cada módulo tinha uma duração diferente, entretanto, em geral, um módulo tinha a duração de um mês, ou seja, dois encontros presenciais, um deles com a participação do OAC.
} 
consistia na integração da teoria à prática, buscando estimular os trabalhadores a problematizar sua realidade e readequar o processo de trabalho. Durante o curso, o Apoio Institucional e o monitoramento das atividades de campo dos educandos foram sendo realizados nas Unidades, envolvendo a equipe completa de Saúde da Família por meio de reuniões. Nestas, ocorriam a descrição das atividades e discussões dos encontros presenciais do curso para os demais membros da equipe, e o debate sobre as atividades que vinham sendo implantadas na Unidade de Saúde, identificando as dificuldades e facilidades, para repactuações de ações.

\section{Conhecendo o Município da experiência}

OMunicípio X com 66.865 mil habitantes ${ }^{4}$, polo de uma Região de Saúde composta por dezenove municípios. Possui Gestão Plena municipal e sedia serviços descentralizados do governo do Estado para a região, como Diretoria Regional de Saúde - DIRES, Diretoria Regional de Educação e Cultura - DIREC, Centro de Hemoderivados da Bahia - HEMOBA.

No ano de 2010, o Município X possuía na conjuntura de serviços de saúde implantados na rede pública: Centro de Atenção Psicossocial (CAPS), Centro de Especialidades Odontológica (CEO), Farmácia Popular, Farmácia Básica, duas equipes de Núcleos de Atenção à Saúde da Família (NASF), um Hospital Regional, uma Policlínica ou Centro de Especialidades Médicas (CEM), Centro de Testagem e Aconselhamento/Serviço de Assistência Especializada para doenças sexualmente transmissíveis/ HIV/AIDS e Hepatites virais (CTA/SAE), Centro de Reabilitação Fisioterápica e

\footnotetext{
${ }^{4}$ Segundo contagem populacional do IBGE em de2007.
}

Central de marcação de exames, dezesseis equipes de Saúde da Família (cobertura de $99,7 \%$ da população), doze equipes de Saúde Bucal -cobertura de $81,3 \%$ da população,(Cadastro Nacional de Estabelecimentos de Saúde $\neg$ CNES $/ 2010)^{5}$. E a rede de saúde particular, contava com clínicas especializadas, hospital, laboratórios, sendo alguns desses serviços conveniados com o SUS.

A organização da Atenção Básica no Município X estava estruturada na lógica da Estratégia Saúde da Família, pensada como uma proposta de mudança de modelo assistencial, regionalizada, descentralizada e pautada na humanização do atendimento, tendo como objetivo primordial desenvolver ações de promoção, prevenção, controle e recuperação à saúde.

\section{A experiência da construção da Linha de Cuidado: um trabalho coletivo}

Durante os encontros presenciais dos cursos, o grupo começou a refletir sobre a organização da rede de atenção à saúde municipal e percebeu que os déficits na integração e o fluxo do paciente na rede de cuidado e entre profissionais de saúde dificultavam o acesso dos usuários a diversos serviços e tecnologias nos âmbitos local e regional. Diante disso, iniciou-se uma discussão sobre a necessidade da criação e implantação de Linhas do Cuidado, delimitando e organizando as ações e os fluxos de atenção na rede de serviço e a integralidade da saúde, frente ao contexto epidemiológico e social do Município X.

$\mathrm{O}$ grupo, motivado pelos debates que aconteciam a

${ }^{5}$ http://cnes.datasus.gov.br/ 
partir dos cursos de especialização, viu que era importante para o Município X sede da Região de Saúde, implementar e implantar alguma das Linhas de Cuidado, direcionando os serviços à uma melhor organização e provável exemplo para os demais municípios dessa região. Então, fomos dialogar com a Secretária Municipal de Saúde sobre a proposta de atuarmos na implantação de Linhas de Cuidado, no Município. A gestão colocou-se disponível para apoiar no desenvolvimento desse modelo de organização dos serviços.

Ao selecionar a Linha de Cuidado a ser estudada e planejada para a realidade do Município X, levando-se em consideração seus indicadores de saúde e a sua rede de serviços de saúde, dialogou-se sobre as necessidades locais. Diante das reflexões realizadas, o debate trouxe a priorização das Linhas de Cuidado a serem implantadas: (1) Materno-Infantil; (2) Acolhimento às Urgências na Atenção Básica; (3) Saúde da Criança; (4) Saúde do Adulto, com ênfase no controle de hipertensão, diabetes e dislipidemias.

Assim, a assistência materno-infantil tornou-se prioritária, na medida em que ficou evidente a necessidade da gestão municipal de saúde em cumprir metas e pactos realizados com o governo estadual e com a Organização Pan-Americana de Saúde, para a redução da mortalidade materna e infantil, até 2014. O Município X configura-se no cenário baiano como prioritário para desenvolvimento de ações relacionadas à qualificação do processo de trabalho e à implantação de serviços, com ênfase na saúde infantil e materna, uma vez que obtém altas taxas de mortalidade infantil, principalmente de óbitos neonatais e mortes maternas indesejadas.

Em julho de 2009, realizou-se o módulo "Saúde da Mamãe e do Bebê" tendo como atividade da disciplina, o mapeamento da rede municipal de saúde para o cuidado à gestante de baixo e alto risco, seguindo os eixos: a) as práticas clínicas e o processo de trabalho; b) os equipamentos existentes no Município $X$ e na Região de Saúde para assistência à gestação, ao parto, puerpério imediato e neonato; c) os aspectos facilitadores e limitantes para organização da rede de atenção materna.

Com os dados cartografados, foi possível aprofundar as reflexões com intuito de buscar estratégias de ação para a reestruturação dessa rede de atenção. Os gestores e trabalhadores, que participaram desse diálogo e construção, consideravam que o modelo de cuidado do Município $X$, naquele período, estava inadequado para prover qualidade e resolubilidade no atendimento materno-infantil. Percebiase que era fundamental resgatar a responsabilidade pelo desenvolvimento da saúde no Município $X$, tendo como base, fortalecer os indicadores do Pacto pela Vida e de Gestão, interligando-os ao Plano Municipal de Saúde.

Com a construção da Linha de Cuidado MaternoInfantil, buscava-se também prover melhor atenção à saúde da mulher, desde o planejamento familiar até o pós-parto, além do atendimento integral aos recém-nascidos. No decorrer do tempo, nos momentos à distância (por e-mail, Ambiente Virtual de Aprendizagem) e nos presenciais, trocava-se informações, encaminhando modelos e propostas, revisando e sugerindo, e, construindo passos para o caminhar dessa construção. O Apoio Institucional posto na relação de trabalho entre a técnica sanitarista, servidora na Diretoria de Atenção Básica do Governo do Estado da Bahia, e gestores e trabalhadores municipais foi sendo desempenhado, podendo ser encontrado desde o estímulo das propostas trazidas nas reflexões teóricas dos cursos, problematizando a realidade vivenciada pelos trabalhadores, à participação direta na construção da Linha de Cuidado. 
Por meio do Apoio Institucional fui buscando levantar as discussões e estimular a escrita, tendo consciência que esta primeira implantação serviria de modelo para a criação das Linhas de Cuidado subsequentes no Município X. Assim, desde já se estaria reorganizando a rede assistencial e os seus fluxos de acesso para os usuários, com normas e processos definidos, contribuindo para o atendimento integral da saúde. O Apoio Institucional foi sendo, desse modo, construído e planejado mediante as necessidades percebidas no decorrer dessa experiência.

Diante do exposto, entendia-se como importante a definição de estratégias de ação para qualificação da assistência à saúde materno-infantil. Para isso foi realizada uma reunião, onde os gestores e trabalhadores municipais, componentes do NR-EP, identificaram e definiram as necessidades de ações, subdividindo-se em quatro grupos de trabalho, compostos cada um por três profissionais.

Cada grupo ficou responsável por aprofundar os estudos, refletir e desenvolver parte da Linha de Cuidado, que ficou subdividida em três temas, sendo descritas as ações necessárias e viáveis para qualificar o caminhar da mãe e da criança dentro da rede de assistência, respeitando os princípios e diretrizes do SUS e da Atenção Básica. As ações estariam descritas dentro das possíveis formas de organização do processo de trabalho, seguindo o fluxo do usuário, tendo como prioridade, o primeiro acesso à Atenção Básica até a resolutividade das necessidades de saúde do usuário. A construção ficou dividida, desse modo, em temas e subtemas, a saber:

1.Planejamento Familiar: Educação e orientação no planejamento familiar (pré e pós-concepcional); Garantia do acesso dos usuários a todos os métodos conceptivos e contraceptivos; Desburocratização do acesso aos métodos de contracepção não hormonais/definitivos
(DIU, Laqueadura, Vasectomia etc.); Mobilização social com formação de grupos específicos de adolescentes e jovens (ambos os sexos) com orientação sexual, estímulos de práticas esportivas, trabalho e renda, apoio espiritual; Corresponsabilização da comunidade;

2.Gravidez: Captação precoce da gestante; Diagnóstico e 1a consulta de pré-natal; Formação de grupos de gestantes; Reorganização da rede de realização de exames e implantação da Central de Marcação com critérios de prioridades bem estabelecidos; Promoção de Educação Permanente e capacitação das equipes de Saúde da Família e Unidades Satélites quanto à implantação desta linha de cuidado; Aumento e qualificação das visitas domiciliares; Encaminhamento das gestantes de alto risco aos serviços de referência e contra-referência: Humanização da atenção obstétrica;

3. Parto e Puerpério: Aumento do número de leitos de média e alta complexidade; Estruturação e garantia da rede de fluxos; Garantia de insumos e medicamentos para tratamento de complicações obstétricas e neonatais; Criação de núcleo de referência técnica de vigilância de óbito materno-infantil; Garantia do acompanhante da gestante durante o trabalho de parto; Incentivo ao aleitamento materno; Garantia da assistência neonatal; Garantia da permanência da parturiente no mínimo 24 horas em parto normal e nas 48 horas para parto Cesário e 72 horas para complicações; Foco ao pré-natal e às atividades educativas, o trabalho de parto e puerpério; Oferta da vitamina " $A$ " a puérpera, pós-aborto, na maternidade e alimentar sistema rotineiramente; Dispensação do apoio laboratorial na maternidade, com qualidade e rapidez; Realização de testes sorológicos para VDRL (para identificar Sífilis) e HIV na maternidade; Realização de outros exames conforme necessidade por ocasião do internamento; Disponibilização da vacina "Matergan" também para os casos de parto 
em domicílio; Garantia de no mínimo duas consultas preconizadas pelo Ministério da Saúde (2006); Realização de orientações para evitar infecções/complicações puerperais; Notificação compulsória e investigação de doenças e agravos à saúde .

Após a descrição da Linha de Cuidado MaternoInfantil, percebeu-se que sua implantação e implementação não seriam possíveis se os outros atores da rede de apoio à saúde não fossem envolvidos no processo de elaboração da Linha de Cuidado e não apenas pelos trabalhadores e gestores da Atenção Básica. Então, refletiu-se sobre a importância de reunião ampliada com representantes de todos os serviços e programas diretamente relacionados ao desenvolvimento da Linha de Cuidado Materno-Infantil. Seguindo essa proposta, posteriormente se desenvolveria diálogo para pactuação com a Câmara de Vereadores, Conselho Municipal de Saúde, serviço de especialidade, serviços de apoio diagnóstico e farmacêutico, hospital regional e do grupo de gestores da Secretaria Municipal de Saúde.

Daí que foi realizada uma reunião ampliada com a presença dos representantes de toda a rede de saúde: Rede hospitalar Pública/Privada e Regulação Externa, Regulação Interna e Rede Laboratorial, Policlínica/CEM (Obstetras, referência em HIV/DST), Vigilância Epidemiológica, DIRES, CAPS, CEO, Rede Clinica Privada de Atenção Obstétrica, Assistência Farmacêutica, NASF, CTA/SAE, Saúde da Mulher, Comissão Intergestores Regional, Equipe de Governo, Câmara de Vereadores, Conselho Municipal de Saúde, Conselhos Locais de Saúde, trabalhadores da Estratégia Saúde da Família, agentes comunitários de saúde, bem como outros atores sociais.

O foco principal dessa primeira reunião foi dialogar sobre Linhas de Cuidado, seus objetivos e apresentar a versão inicial do plano de cuidado materno-infantil para a rede de saúde e conclamar aos participantes a se envolverem no projeto, apoiando na construção das especificidades de cada serviço, e pactuar fluxos, normas e rotinas de funcionamento da rede municipal materna e infantil.

$\mathrm{Na}$ primeira reunião ampliada, com presença de representantes da maioria dos serviços municipais, percebeu-se, naquele momento, que não seria fácil realizar a implantação dessa proposta, a medida que foram surgindo questionamentos dos profissionais presentes em defesa da centralização das ações no núcleo profissional de cada categoria, principalmente entre o grupo de especialistas. As discussões demonstraram uma conformação do sistema de saúde direcionada para o trabalhador e ou gestor, tendo em parte dos representantes, a cultura de um "saber" fragmentado, unidirecional e não centrado na saúde dos usuários.

Entendendo a importância do envolvimento do coletivo de trabalhadores para a construção e implementação de uma atenção à saúde integral, equitativa e resolutiva, fazia-se substancial o diálogo intrassetorial e multiprofissional, como pilar para modificação dos processos de trabalho e reorganização da assistência. A proposta era que a Linha de Cuidado se configurasse como fruto de um grande pacto entre os trabalhadores e gestores de todos os serviços que organizariam, promoveriam e controlariam as ações e os recursos assistenciais, tendo a Atenção Básica como ordenadora da rede de atenção no cuidado materno e infantil no Município.

Após o primeiro encontro, ficou pactuada a realização de visitas e discussão com o grupo de profissionais de cada setor, serviço ou programa de saúde implantado no Município X, cujo propósito era planejar e pactuar a 
organização e fluxo de atividades direcionadas aos diferentes setores, envolvendo e conquistando paulatinamente toda a rede de apoio à saúde.

Assim, foi se definindo qual seria o papel do coletivo de trabalhadores (educandos dos cursos) atuantes nas respectivas Unidades ligadas à Linha de Cuidado, em construção. Os produtos dessas reuniões contribuíam com o desenho do esboço da Linha de Cuidado Materno- Infantil até a sua concepção final. Os trabalhadores subdividiramse, responsabilizando-se de prover e debater o assunto com cada setor da assistência, com os quais tivessem maior afinidade, de acordo com o subtema da Linha de Cuidado Materno-Infantil. Dessa forma, esses trabalhadores foram buscando contribuições e corresponsabilização no processo de qualificação à saúde, envolvendo atores estratégicos para a realização de mudanças nos processos de trabalho, para oferecimento de uma saúde mais eficaz e resolutiva ao cuidado materno-infantil.

O diálogo com a rede de apoio à saúde foi exitoso na medida em que diversos trabalhadores puderam conhecer e se inteirar dos serviços e ações oferecidos aos usuários no Município, sendo esses públicos e/ou privados.

Após construir a Linha de Cuidado Materno-Infantil, os fluxos, as normas e rotinas de seu funcionamento no Município, havia outras barreiras a serem enfrentadas. Surge a oposição da gestão e de alguns profissionais, obstetras e pediatras, no desenvolvimento de algumas pactuações sociais e ações e serviços no âmbito do Município.

Assim é que, os obstetras não concordavam que o levantamento e a regulação da gestante de risco fossem realizados pelos enfermeiros ou médicos da equipe de Saúde da Família. Vale dizer que as gestantes no Município chegavam ao obstetra por formas diversas, como por exemplo: por meio de afinidades com vereadores, parentescos, amizades, bilhetes da gestão, além dos encaminhamentos das equipes de Saúde da Família. Por isso, a agenda dos obstetras, sempre concorrida, não dava conta de atender mensalmente as gestantes de risco. A remarcação era definida pela vaga disponível na agenda e não por prioridade e regularidade no acompanhamento. Havia gestantes que continuavam o atendimento paralelo na Unidade de Saúde da Família e em outros serviços. Por essa definição de risco, perdia-se o vínculo do acompanhamento longitudinal na Atenção Básica. Não havia controle sobre a demanda, ou mesmo classificação do risco obstétrico. A Atenção Básica não era ordenadora da rede, e havia resistência pelos gestores e obstetras a esse modelo, colocando a capacidade técnica de enfermeiros e médicos da Saúde da Família como duvidosa para classificar e ordenar a demanda do risco obstétrico.

Os pediatras acreditavam que além da primeira consulta ao recém-nascido na maternidade, o acompanhamento desse recém-nato deveria estender-se por todo o primeiro ano de vida, sendo somente a partir daí acompanhado pela equipe de Saúde da Família, caso estivesse fora de risco.

Estava presente o medo de mudança no modelo de atenção e do uso do conhecimento tradicionalmente centrado no trabalhador e gestor no sistema de saúde. O uso iminente de novas tecnologias, no campo materno infantil, atrelado ao consumismo e acumulação financeira, também influenciou na implantação da Linha de Cuidado. As demandas de exames não seguiam o protocolo estabelecido pelo Ministério da Saúde. A clínica vinha sendo influenciada pela mídia farmacológica, estética e de serviços privados de saúde. Tal contexto deixava os profissionais da Saúde da Família inseguros na tomada de decisão com relação a gestantes de risco que já estavam sendo acompanhadas 
nas Unidades de Saúde da Família e com os obstetras no Centro de Especialidades Médicas.

No entanto, no processo de construção da Linha de Cuidado Materno-Infantil, os trabalhadores da Atenção Básica que participavam do Curso de Especialização, e de alguns serviços da rede (CAPS, Farmácia, CEO) foram atuando em suas unidades produtivas, envolvendo a própria equipe de trabalho, produzindo reflexão-ação no processo de trabalho, provocando mudanças nas ações e estruturas dos serviços para com o cuidado materno e infantil.

A Linha de Cuidado Materno-Infantil, embora não tenha sido implantada/implementada no Município $\mathrm{X}$, proporcionou algumas mudanças efetivas, principalmente nos processos de trabalho dos trabalhadores e gestores que participaram de sua construção, influenciando diretamente nos resultados em cada equipe de Saúde da Família. O protagonismo e autonomia dos servidores, dentro da dinâmica e fluxo de serviços no Município, facilitaram o acesso e regulação dos usuários aos serviços, tendo o Acolhimento como resultado mais eficaz de todo movimento provido nessa construção.

Mediante as propostas levantadas pela Linha de Cuidado, foi possível a criação da Comissão de Farmácia e Terapêutica, que discutiu e modificou o elenco básico de medicamentos da farmácia básica, e assim possibilitou acrescentar ou melhorar a qualidade e quantidade de medicamentos e insumos oferecidos para a saúde da mulher, gestante e bebê em todos os seus aspectos no Município.

Além disso, outros avanços foram observados em algumas Unidades de Saúde da Família, como: implantação do Acolhimento, proporcionando atendimento humanizado e triagem com classificação de risco; aprimoramento e ampliação de parcerias com outros setores sociais e da saúde (escolas, igrejas, associações, Centro de Referência de Assistência Social, Centro de Referência Especializado de Assistência Social, Núcleo de Apoio a Saúde da Família, Conselhos Locais de Saúde); maior integração entre os profissionais das equipes de Atenção Básica, levando à divisão de responsabilidades e corresponsabilização por todas as ações desenvolvidas na Estratégia de Saúde da Família (ESF).

Foi possível notar as mudanças no trabalho multidisciplinar nas equipes de Saúde da Família e sua relação com as equipes de Saúde Bucal, trazendo discussão de condutas no processo de trabalho, com inserção do odontólogo em todas as ações, principalmente na consulta de pré-natal. Entre as melhorias observamos adequação nas estruturas físicas de algumas Unidades de Saúde da Família (USF), embora com algumas ressalvas; formação de Conselhos Locais de Saúde; maior aproximação dos gestores com os profissionais e com a comunidade, com a participação mais frequente dos gestores nas reuniões de equipe nas USF e dos setores da rede de apoio. A participação dos gestores teve aumento também nas reuniões dos Conselhos Locais de Saúde, visando à promoção do controle social/participação popular nas ações do SUS, ampliandose a visão dos gestores da rede de apoio à saúde, com o reconhecimento das facilidades e dificuldades para sua reestruturação.

Contudo, no decorrer da construção desta Linha de Cuidado e dos esforços para implantá-la, o Município $X$ começou a vivenciar algumas adversidades, principalmente no que se refere à gestão de recursos financeiros, que dificulta a tomada de decisões e desenvolvimento das estratégias de ações pensadas para qualificação da saúde no município, bem como prejudica o diálogo com a rede de apoio à saúde e consequente implementação da Linha de Cuidado. 
Com as rodadas de reuniões, ficou evidente que cada setor da média e alta complexidade estava focado apenas nos seus problemas individuais em detrimento dos interesses da coletividade, principalmente os profissionais da categoria médica, os quais demonstraram mais dificuldade em entender e colaborar com a implantação/ implementação das Linhas de Cuidado.

Vale considerar que a comunicação entre os diferentes setores da rede de apoio à saúde local é de extrema importância, uma vez que o desenvolvimento de atividades de forma intersetorial é bastante complexo e sua operacionalização depende da superação das hierarquias existentes nas instituições e, principalmente, das relações de poder existentes entre as categorias profissionais, políticas locais e segmentos que compõe a rede de saúde e social do Município.

A implantação da Linha de Cuidado não foi possível por motivos diversos, que vão desde a dificuldade de diálogo e sensibilização dos gestores acerca da importância do investimento na Atenção Básica como ordenadora do cuidado e da rede, até a pouca participação dos trabalhadores da saúde da média e alta complexidade enquanto coautores e corresponsáveis pelas ações estratégicas para mudança e/ou qualificação de modelo de atenção em saúde.

Para que o modelo de atenção passe a estar focado nas ações de prevenção, promoção, proteção à saúde, visando à integralidade da atenção, causando impacto positivo sobre os problemas de saúde das pessoas e da população, necessário se faz manter o diálogo e a busca por novas parcerias e novas formas de encantamento dos outros setores da saúde e da própria Atenção Básica, em busca de uma assistência que seja universal, integral, equitativa, e principalmente, resolutiva.
Entendendo a saúde como multidimensional, com serviços e ações que interdependem de diversos atores e setores envolvidos na produção do cuidado, faz-se importante o desenvolvimento de parcerias com a rede de apoio à saúde e com a Atenção Básica. Visualizar a condição real posta na rede de serviço local, que além de uma negociação de práticas e transferência de responsabilidades, é também uma variável fundamental para planejamento das ações que levem a organização eficiente dos serviços. Promoção de rodas de conversa e espaços de comunicação que possibilitem definição de conceitos e objetivos de interesse mútuo, culminando com o planejamento participativo das ações que demandam contribuições de toda a rede de apoio à saúde não deve ser esquecida ou minimizada para essa lógica de modelo de organização e de atenção.

Por fim, esta experiência permitiu observar que, de alguma forma, é necessário não somente uma discussão para além da importância da implantação e implementação das Linhas de Cuidado como proposta norteadora da reorganização da assistência à saúde, mas também uma discussão que amplie o debate e permita contribuir com a formação de sujeitos críticos e reflexivos que tenham potencial para intervir na realidade da saúde local e permita aos usuários terem um atendimento de qualidade, eficaz e resolutivo, além de evitar desgaste dos atores envolvidos na rede de apoio à saúde municipal. 


\section{Referências}

BAHIA. Comissão Intergestores Bipartite da Bahia. Resolução CIB no. 275 de 19 de junho de 2012. Aprova as regiões de saúde do Estado da Bahia e a instituição das Comissões Intergestores Regionais. Disponível em < http://www2.saude.ba.gov.br/cib/arquivos / Resolu\%C3\%A7\%C3\%B5es\%20da\%20CIB/2012/ Resolu\%C3\%A7\%C3\%B5es\%20CIB\%20de\%20151\%20a\%20 300.pdf>. Acesso em: 12 jan 2014

BAHIA. Secretaria da Saúde. Escola Estadual de Saúde Pública. Projeto Político Pedagógico. Curso de Especialização em Saúde da Família e Gestão da Atenção Básica, com Ênfase na Implantação das Linhas de Cuidado. Salvador: 2009.

BRASIL. Ministério da Saúde. Secretaria de Atenção à Saúde. Departamento de Ações Programáticas Estratégicas. Área Técnica de Saúde da Mulher. Pré-natal e Puerpério: atenção qualificada e humanizada - manual técnico. Brasília: Ministério da Saúde, 2006. Série A. Normas e Manuais Técnicos - Série Direitos Sexuais e Direitos Reprodutivos Caderno no 5 .

PINTO, H. A. Linhas de Cuidado na Bahia: um conceito em viva produção. Revista Baiana, v. 33, n. 1, p. 22-34, 2009. Disponível em: http://inseer.ibict.br/rbsp/index. php/rbsp/ article/ viewFile/185/pdf_2. Acesso em 23 maio 2014.

\section{Acolhimento aos novos Gestores na Ma- crorregião Leste: um relato de experiência}

\author{
Kally Cristina Soares Silva \\ Co-autores: Isadora Queiroz Ribeiro, Marta Caires de Sousa, Maiza \\ Conceição Teles Dias, Morgana Bastos Barreto, Sílvio Roberto Medina
}

Lopes

"A revolução só pode ser filha das ideias..."

Fidel Castro

\section{Introdução}

A ideia de relatar a experiência do acolhimento institucional aos novos gestores municipais no Estado da Bahia no que diz respeito à saúde e com recorte para a Atenção Básica é motivada pelo ideário de que as ações do Apoio Institucional podem influenciar para a mudança do modo de gerir o Sistema Único de Saúde (SUS) e de produzir o cuidado em saúde. De acordo com a Política Nacional de Humanização (BRASIL. Ministério da Saúde. Secretaria de Atenção à Saúde. Núcleo Técnico da Política Nacional de Humanização, 2008) o acolhimento como ato ou efeito de acolher expressa, em suas várias definições, uma ação de 
aproximação, um "estar com" e um "estar perto de", ou seja, uma atitude de inclusão. O acolhimento implica em interação, estar em relação com algo ou alguém. Desse modo, o acolhimento aos novos gestores da Macrorregião Leste se insere numa diretriz mais ampla onde o Governo do Estado e a Secretaria da Saúde do Estado da Bahia (SESAB) buscam qualificar a relação entre os entes federados, aproximando-se das gestões municipais na perspectiva de construção de uma relação cooperativa no enfrentamento dos desafios ainda presentes no Estado.

A Macrorregião Leste é composta por quarenta e oito municípios com total de 4.659 .442 habitantes, correspondendo a um terço da população total do Estado da Bahia; engloba a Capital $\neg$ Salvador, os municípios da Região Metropolitana e da Região do Recôncavo. Conforme - Plano Diretor de Regionalização do Estado (BAHIA. Comissão Intergestores Bipartite da Bahia, 2012), esta Macrorregião está dividida em quatro Regiões de Saúde: Camaçari, Cruz das Almas, Salvador e Santo Antônio de Jesus. Quanto à gestão descentralizada, possui quatro Diretorias Regionais de Saúde (DIRES), localizadas nos municípios de Amargosa, Cruz das Almas, Salvador e Santo Antônio de Jesus. A Macrorregião é prioritária para implantação e desenvolvimento das Redes de Atenção à Saúde (RAS) e demais projetos estratégicos do Ministério da Saúde (MS). Constitui-se na Macrorregião mais populosa do Estado; a Capital $\neg$ Salvador possui cerca de dois milhões e oitocentos mil habitantes; três municípios possuem população acima de cem mil habitantes, e cinco municípios possuem população acima de cinquenta mil habitantes.

No que diz respeito às características socioeconômicas é possível afirmar que se trata de uma região heterogênea, com profundas desigualdades econômicas, na oferta de serviços de saúde, bem como, desigualdades na capacidade de gestão. Um cenário pós-eleição do ano de 2012 e pósdiplomação dos prefeitos eleitos fazendo parte do públicoalvo, juntamente com o segmento da saúde de suas equipes de transição.

A atividade denominada de acolhimento aos novos gestores da Macrorregião Leste foi executada pelos Apoiadores Institucionais da equipe de referência de Apoio Institucional da Diretoria de Atenção Básica da Secretaria da Saúde do Estado da Bahia (DAB/SESAB) ${ }^{1}$ em parcerias com os Apoiadores e técnicos das Diretorias Regionais de Saúde, com os coordenadores dos Núcleos Microrregionais de Educação Permanente na Atenção Básica $\neg N M R / A B-$ (BAHIA, Leis, etc., 2013), Apoiadores da Fundação Estatal Saúde da Família (FESF-SUS) e técnicos de outras diretorias da SESAB.

Experiência anterior já havia sido vivenciada pela DAB, quando, após as eleições do ano de 2008 , foram realizados vinte e oito encontros regionais, para recepcionar os novos gestores (prefeitos eleitos e suas equipes de transição da saúde), com o objetivo de aproximá-los ao setor saúde, sensibilizá-los quanto à importância da Atenção Básica enquanto estratégia de organização da rede de serviços de saúde dos municípios e Regiões de Saúde, bem como, apresentar a Política Estadual da Atenção Básica, os programas, projetos e ações estratégicas Federal e Estadual, que estariam acessíveis aos novos gestores.

Diante da avaliação positiva desta experiência e da necessidade de aprimorá-la, uma nova rodada de encontros de acolhimento de novos gestores foi proposta e desenvolvida pela DAB em 2012. Nesta nova versão foi dada elevada autonomia às equipes de Apoio Institucional

${ }^{1}$ A Diretoria de Atenção Básica compõe o organograma estrutural e funcional da Superintendência de Atenção Integral à Saúde (SAIS) da Secretaria da Saúde do Estado da Bahia. 
para que os métodos e conteúdos fossem adequados às realidades das Macrorregiões e Regiões de Saúde, sempre em estreito diálogo com as DIRES e coordenações da DAB: Coordenação de Apoio e Desenvolvimento (COAD), Coordenação e Apoio Matricial (COAM) e Coordenação de Gestão de Projetos (COGEP).

O Apoio Institucional é a estratégia de gestão adotada pela $\mathrm{DAB}$, enquanto um modo de realizar gestão, buscando novas formas de operar e de se relacionar com os diferentes sujeitos. Assume como objetivo a mudança nas organizações, misturando e articulando conceitos e tecnologias advindas da análise institucional e da gestão (OLIVEIRA, 2011). A constituição desta estratégia fundamenta-se em teorias e práticas que procuram articular o campo da política e da gestão com saberes e experiências originárias da psicanálise, da pedagogia e da análise institucional (CAMPOS, 2005).

Ainda na compreensão do Apoio Institucional, o mesmo pode ser entendido como um dispositivo de funcionamento em rede. Desse modo, os interstícios, os bastidores não devem ser ignorados; eles estão presentes, atravessando, influenciando, transversalizando. Enfim, nas análises realizadas o Apoio abre a possibilidade de funcionar como articulador, como conector, produzindo novos territórios, borrando, embaralhando lugares previamente constituídos como aqueles convencionalmente denominados, identificados, dicotomizados como lugares de gestão e de atenção, de trabalhadores de saúde e de usuários. O Apoio Institucional tem caráter híbrido, sem ponto de partida e de chegada; é feito em meio, no entre, nas margens, movimentando-se e pondo a movimentar os pontos conectados, potencializando a produção de redes (VASCONCELOS, 2009).

Refletiremos neste relato sobre o que foi vivenciado pela equipe, compartilhando as impressões sentidas no desenvolvimento da atividade de acolhimento aos novos gestores. A reflexão sobre a experiência particular, vivida nesses encontros, aponta aspectos relevantes do Apoio Institucional que devem ser levados em consideração para outros momentos e realidades vivenciadas.

\section{Preparação e desenvolvimento dos encontros}

Os encontros foram precedidos de várias pré-tarefas. Praticamente todo o apoio logístico e a mobilização política das representações municipais foram conduzidos com esmero pelas Diretorias Regionais de Saúde.

Inicialmente, o alinhamento interno da proposta dentro da DAB e com as DIRES exigiram diversas reuniões de negociação e pactuação para consensos de conteúdos e formas de abordagem. Definidos os objetivos, conteúdos e metodologia de cada encontro, foi necessária uma análise conjuntural de cada Região de Saúde, no intuito de considerar as estratégias e momentos oportunos para a realização de cada evento, que sofreu adaptações oportunas às circunstâncias de cada encontro.

As indefinições jurídicas referentes a quem assumiria de fato a gestão de um dos municípios, fez com que adiássemos o encontro em uma das regiões para o início do ano de 2013. Todos os demais encontros ocorreram em dezembro do ano de 2012, quando, em tese, seria possível contar com a maior parte dos prefeitos e a possibilidade de influir mais decisivamente no seu plano de governo para a saúde, inclusive na composição de uma equipe de gestão da saúde com perfil adequado, em particular, a equipe gestora da Atenção Básica. 
O envolvimento de outras instituições parceiras nesta ação estratégica, como a Fundação Estatal Saúde da Família e o Ministério da Saúde, exigiram um alinhamento de qual seria o papel de cada um, no desenvolvimento do Apoio Institucional, e, como articular esses apoios para que fossem sinérgicos e não concorrentes. Para tanto, avaliamos a oferta, a disponibilidade de agenda, a capacidade instalada, e o grau de comprometimento dos atores representantes destas instituições, envolvidos nesta ação estratégica.

A elaboração das apresentações que seriam utilizadas na exposição dialogada exigiu uma revisão do marco conceitual e normativo nacional e estadual da Atenção Básica, em especial no que se refere à nova Política Estadual da Atenção Básica (Decreto Estadual no. 14.457 de 2013), que traz diretrizes específicas para este nível de atenção no Estado da Bahia, que dialogam com as singularidades loco-regionais, e às novas portarias do Ministério da Saúde que já estavam sendo publicadas ou que já conhecíamos suas minutas. Um esforço mais intenso de preparação foi empreendido na apropriação por parte dos Apoiadores Institucionais das propostas de governo e realidades de cada município.

Todo o material impresso foi organizado em pastas personalizadas por município, contendo a plataforma de governo dos prefeitos eleitos ${ }^{2}$, informações sobre séries históricas de indicadores sensíveis à Atenção Básica e à Vigilância à Saúde, legislação da Atenção Básica, cartilha do Sistema de Informações sobre Orçamentos Públicos em Saúde (SIOPS), manual dos projetos estratégicos, planilha de financiamento da Atenção Básica e extrato dos repasses fundo a fundo dos recursos vinculados à Atenção Básica. Cada Apoiador Institucional da equipe assumiu a responsabilidade

${ }^{2}$ Disponível em : http://divulgacand2012.tse.jus.br/divulgacand2012/ ResumoCandidaturas.action de se apropriar da realidade de determinado número de municípios. O esforço de apropriação da realidade dos municípios e do marco normativo das portarias promoveu rico processo de Educação Permanente de toda a equipe e em especial daqueles mais novos. Este exercício levou todos nós a uma maior aproximação com as equipes das DIRES, e o reconhecimento de habilidades e competências específicas de seus técnicos, que somadas, proporcionaram grandes potencialidades aos grupos, além de ter induzido grande protagonismo aos Apoiadores Institucionais das coordenações da DAB e Apoiadores das DIRES.

Até momentos antes de iniciar o primeiro encontro, diversos sentimentos permeavam os Apoiadores, um mix de excitação e apreensão. A excitação foi oriunda do forte desejo em realizar a atividade e da intensa energia imprimida às pré-tarefas e pela expectativa sobre a aceitação da proposta. A apreensão, por sua vez, originava-se das dúvidas sobre: adesão ao convite; se teria a presença dos prefeitos ou somente de seus representantes; qual o grau de entendimento desses atores sobre saúde pública; qual o grau de comprometimento dos mesmos com a coletividade; quais as propostas para saúde de seus territórios.

Os encontros foram conduzidos predominantemente pelos Apoiadores Institucionais da DAB em parceria com as DIRES e contou com ampla participação dos municípios, presença da representação da FESF-SUS e outras diretorias da SESAB. A programação foi executada com pequenas adaptações que se fizeram necessárias, atingindo os objetivos propostos, principalmente no fortalecimento do vínculo entre os Apoiadores da DAB e da DIRES com os gestores municipais, na discussão sobre o papel da Atenção Básica, na apresentação da Fundação $\neg$ FESF-SUS como meio de contratação e qualificação do processo de trabalho na Atenção Básica, com destaque para a importância nas 
Redes de Atenção à Saúde com foco na regionalização, marcando a aproximação do Apoio Institucional e oportunizando novas agendas de Apoio local.

Percebemos que os atores municipais presentes nesse encontro ainda esperavam que o Estado assumisse 0 protagonismo da resolução dos seus problemas. Pensavam em um organograma da Secretaria Municipal da Saúde que priorizasse os acordos advindos de suas campanhas eleitorais e a captação de recursos financeiros, em detrimento de uma organização que garantisse o desenvolvimento e execução das ações de saúde, omitindo-se da responsabilidade de estabelecer um modelo de gestão e um modelo de atenção à saúde que produza e expresse cuidado.

Ir além da transmissão de informações e conseguir sensibilizar, estimular, implicar os envolvidos, foi para nós um grande desafio. Não queríamos atuar somente como veículos de e sim, instrumentos de transformação e produção de autonomia.

\section{A proposta para o acolhimento dos novos gestores da Macrorregião Leste}

O Encontro foi previsto para um dia, utilizando a metodologia de exposição dialogada, com a programação do evento dividida em dois momentos:
Quadro1: Programação do evento de acolhimento aos novos gestores

\begin{tabular}{|c|c|}
\hline MANHÃ/ 1 MOMENTO & TARDE/ 2 MOMENTO \\
\hline $\begin{array}{l}\text { 08:30 - Apresentação da } \\
\text { proposta do encontro e } \\
\text { Acolhimento dos Gestores }\end{array}$ & 12:30 - Almoço \\
\hline $\begin{array}{l}\text { 09:00 - Papel da DIRES e } \\
\text { Cartografia da Região de Saúde } \\
\text { (situação epidemiológica, rede } \\
\text { de saúde e fóruns de gestão } \\
\text { regionalizada) }\end{array}$ & $\begin{array}{l}\text { 13:30 - Discussão singular com } \\
\text { os municípios / } \\
\text { Exposição de stands do FESBA, } \\
\text { FESF-SUS e DIRES }\end{array}$ \\
\hline $\begin{array}{l}\text { 09:30 - Contextualização do } \\
\text { SUS e da Atenção Básica }\end{array}$ & $\begin{array}{l}\text { 15:30 - Pactuação das próximas } \\
\text { agendas }\end{array}$ \\
\hline $\begin{array}{l}\text { 10:15 - Intervalo } \\
\text { 10:30 - Apresentação sobre } \\
\text { financiamento da Atenção } \\
\text { Básica }\end{array}$ & 16:00 - Encerramento e avaliação \\
\hline $\begin{array}{l}\text { 11:00 - Ofertas do Apoio } \\
\text { Institucional }\end{array}$ & \\
\hline
\end{tabular}

No primeiro momento, a apresentação do SUS/ Atenção Básica se constituiu pré-requisito para o desenvolvimento do segundo, destacando as suas principais legislações, diretrizes, instâncias de decisões, Controle Social, política de financiamento, projetos estratégicos, redes de atenção e perfil epidemiológico da Macrorregião/ Região de Saúde, ações de saúde desenvolvidas por outras diretorias da Secretaria e as ofertas de Apoio da SESAB, FESF-SUS e Ministério da Saúde. 
Em relação à Atenção Básica, foi dada ênfase especial à Estratégia Saúde da Família, por entender que esta estratégia é uma forma importante de reorganização da Atenção Básica, de forma resolutiva e com equidade. Nesta Macrorregião a ênfase na equipe de Saúde da Família $\neg$ SF tornou-se necessária, visto que muitos municípios, especialmente aqueles de médio e grande porte, até o momento, possuíam em seus territórios equipes de Atenção Básica tradicionais, o que favorece uma baixa cobertura da Estratégia Saúde da Família na Macrorregião, consequentemente no Estado, e compromete a longitudinalidade do cuidado em saúde.

No segundo momento ocorreu a atividade denominada de discussão singular, que consistiu na divisão em grupos formados por gestores de um município e um Apoiador de cada instituição (DAB, DIRES e FESF-SUS). 0 atendimento aos gestores partia do seu próprio programa de governo para a saúde que foi apresentado no pleito eleitoral de 2012, apresentando para o Gestor: a Rede de Atenção à Saúde já instituída; a situação da Atenção Básica do seu município; o teto financeiro deste Bloco de Atenção recebido no ano de 2012 pelo Fundo Municipal de Saúde; as possibilidades reais de ampliação dos serviços e de ações de saúde no seu território; quais os programas estratégicos da Atenção Básica seriam oportunos para implantação no quadriênio 2014/ 2017; os fluxos a serem seguidos a partir da manifestação de interesse; além de serem esclarecidas dúvidas que surgiram no momento da conversa.

Naquela ocasião, dialogando com os chefes do executivo de forma mais próxima e reservada, os mesmos sentiram-se seguros para demonstrar suas fragilidades e receios, decorrentes de suas inexperiências na gestão pública, o que nos impulsionou a orientá-los para além da Atenção Básica, reforçando as ações essenciais para suas equipes de transição, como consultar o Plano Municipal de Saúde ainda vigente para o ano de 2013, Relatório de Gestão, orçamento para saúde, constituição do Conselho Municipal de Saúde, e com estes instrumentos de gestão avaliar o que seria possível executar no primeiro ano de governo.

A discussão singular foi fundamental, e promoveu a aproximação do Apoiador com as novas equipes de gestão, oportunizando diversas agendas de Apoio local. Dentre as visitas de Apoio Institucional requeridas, destacamos as ocorridas em sete municípios, os demais municípios da Macrorregião acessavam o Apoio Institucional somente para encaminhamentos de projetos para a Comissão Intergestores Bipartite (CIB).

Em paralelo às atividades do segundo momento, os municípios que estavam aguardando a discussão singular com os Apoiadores Institucionais podiam acessar stands do Fundo Estadual de Saúde da Bahia $\neg$ FESBA, FESF-SUS, DIRES para obter maiores informações desses setores. À medida que a discussão singular acontecia, crescia a certeza de que estávamos sendo assertivos. Valeu a pena a dedicação, pois a equipe estava no caminho certo, a metodologia estava produzindo os resultados previstos no planejamento da atividade. A avaliação dos presentes foi extremamente positiva, valorizando o conteúdo e o método desenvolvido.

Os gestores mostraram-se bastante interessados nas informações, questionaram sobre as possibilidades de adesão aos projetos, formas de financiamento, bem como suas responsabilidades sanitárias, realizando ao fim do evento uma avaliação muito positiva da estratégia adotada para acolhê-los, considerando que esse momento foi muito oportuno e importante para eles nesse início de governo, em que muitos assumiriam a Secretaria Municipal de Saúde, seja na função enquanto secretário, ou nas funções como diretores e coordenadores, sem experiências anteriores em 
gestão, nem mesmo na área da saúde. Muitos afirmaram que não tinham noção da responsabilidade do exercício dos cargos de prefeito e secretário da saúde, bem como da quantidade de possibilidades que foram mostradas e que, a partir daquele momento, teriam muito trabalho para executar e desafios a serem superados. O que foi explanado e esclarecido no evento foi fundamental para o ponto de partida que iniciaria no primeiro dia do ano de 2013.

\section{Considerações Finais / Análise do Encontro}

A experiência relatada provoca algumas reflexões interessantes para quem está imbuído dos desafios de realizar o Apoio Institucional aos municípios. Primeiro, porque o momento foi de fato oportuno para a realização dos encontros, no qual, a grande maioria dos municípios estava em transição de governo e definindo seu projeto para a saúde e sua equipe gestora. $O$ aprofundamento da discussão encontrou um ambiente de atenção importante por parte dos tomadores de decisões municipais, a respeito da situação de saúde municipal, o papel e responsabilidade dos gestores para com a saúde dos munícipes e a importância no que se refere à priorização e direcionalidade das ações de saúde. Em segundo lugar, por nos parecer fundamental para a transformação do modelo de atenção e gestão da Atenção Básica que os prefeitos e secretários da saúde sejam envolvidos numa reflexão profunda sobre os modelos que pretendem implantar em seu município. Os coordenadores da Atenção Básica e os secretários municipais da saúde, que participaram do evento, enfatizaram a importância de um agente externo ao município aprofundar o debate com o prefeito tal como o ocorrido.
De fato, a mobilização da representação social do potencial técnico-político que o Apoiador Institucional carrega consigo, no momento do diálogo com o Prefeito Municipal, constitui uma oportunidade de ofertar informações sobre a legislação e o funcionamento do setor da saúde, subsidiando a escolha qualificada da sua equipe da Secretaria Municipal de Saúde e legitimando essa gestão para a realização das transformações necessárias na Atenção Básica, atendendo às necessidades da população. Assim sendo, eventos como esses, tendo os prefeitos municipais como público-alvo, devem ser proporcionados em outros momentos ao longo da gestão, tal como muitos solicitaram durante os encontros.

Outro aspecto relevante foi o modo coletivo como o evento foi construído e executado num clima reflexivo, criativo, participativo, propositivo e de corresponsabilização. Os parceiros e participantes do evento experimentaram "em ato" a estratégia de Apoio Institucional, requalificando as relações entre os diversos atores envolvidos (municípios, SESAB, FESF-SUS e MS) estimulando práticas democráticas e solidárias e proporcionando um rico aprendizado pessoal, profissional e institucional quanto ao modo de "fazer Apoio". A discussão singular com cada município, certamente, foi o que mais simbolizou essa experiência.

Vale a reflexão sobre o desafio de se promover a integração da Atenção Básica com outros setores. A realização da primeira agenda pública conjunta $D A B$ e DIRES com os novos gestores conseguiu atrair a atenção não só do público pretendido, mas de outros setores da SESAB que reivindicaram a diretriz de integração da Atenção Básica com a Vigilância ou com a Assistência Farmacêutica, por exemplo, "romper as caixinhas", para que fosse disponibilizado espaço na programação para uma exposição dialogada específica não prevista na metodologia 
do encontro. Mas será que a integração acontece quando diferentes setores realizam exposições dialogadas num mesmo encontro, ou quando cada setor ou mesmo os dois constroem uma proposta de ação articulada, não só no espaço e tempo, mas essencialmente, nas práticas do cuidado e da gestão?

A realização desses encontros proporcionou aos Apoiadores Institucionais um aprendizado significativo para melhoria do seu "fazer Apoio", como: o desenvolvimento de novas estratégias de comunicação com os gestores; a identificação do Plano de Governo como um canal de comunicação entre os Apoiadores e os chefes do executivo; a importância de construir um planejamento para a execução do Plano de Governo no que tange à saúde; a utilização do método da discussão singular como uma possibilidade de demonstração do Apoio Institucional. Além disso, promoveu o vínculo com estes gestores, situação esta que facilita o diálogo com o Município e a construção de uma agenda futura.

A "função" Apoio é um recurso que procura intervir de forma interativa, uma função que considera que a gestão se exerce entre sujeitos, ainda que com distintos graus de saber e de poder, e que produz efeitos sobre os modos de ser e de proceder destes sujeitos e das organizações (VASCONCELOS, 2009). Considerando que muitos desses sujeitos novos gestores, apresentam o poder político, o qual segundo, Testa (2004), trata-se do poder com capacidade de mobilizar recursos, grupos sociais em demanda ou reclamação de suas necessidades e interesses. Consideramos como fator importante investir no poder administrativo e técnico dos mesmos.

Dessa forma, concluímos ser estratégico que a Diretoria de Atenção Básica continue realizando momentos de acolhimento aos novos gestores municipais, no período de transição dos governos, para que se possa fortalecer - Apoio ofertado pelo Estado, possibilitando minimizar as improbidades administrativas, induzir o planejamento das ações e a adesão qualificada aos projetos estratégicos ofertados. Acreditamos que a parceria entre diferentes atores refletirá na qualificação da gestão da Atenção Básica, provocando transformação na situação de saúde dos territórios e nas condições de vida da população. E, finalizamos compartilhando que convêm para muitos municípios em início de gestão realizar um esforço de produção de consensos progressivos entre a equipe de direção da saúde e até mesmo outros atores relevantes (prefeitos, vereadores, membros do Conselho Municipal de Saúde, trabalhadores) a respeito dos propósitos que se pretende alcançar. A visão de mundo de cada ator pode apontar para direções muito distintas, e o mínimo de alinhamento pode ser necessário até mesmo para enxergar os aspectos explicativos da situação-problema que se deve aprofundar.

Oliveira (2011) afirma que os objetivos do Apoio Institucional estão voltados para a produção de análise e transformação dos processos de trabalho e dos modos de relação entre sujeitos em uma organização, sendo um arranjo organizacional ou modalidade de prática direcionada para processos de gestão seja no apoio a gerentes ou a processos de cogestão.

Concordando com sua afirmativa, pretendemos com essa atividade desenvolver, mesmo que de forma incipiente, porém continuada, a autonomia e protagonismo dos sujeitos que fazem o SUS acontecer, como também, aumento da capacidade de análise e de intervenção dos sujeitos, no contexto em que se encontram e vivem, buscando resolutividade dos serviços de saúde, garantindo assim, melhores condições de vida às pessoas. 


\section{Referências}

BAHIA. Comissão Intergestores Bipartite da Bahia Resolução CIB no.275 de 19 de junho de 2012. Aprova as regiões de saúde do Estado da Bahia e a instituição das Comissões Intergestores Regionais. Disponível em: < http://www2.saude.ba.gov.br /cib/arquivos/ Resolu\%C3\%A 7\%C3\%B5es\%20da\%20CIB/2012/ Resolu\%C3\%A7\%C3\%B5es\%20CIB\%20de\%20151\%20a\%20 300.pdf>. Acesso em: 12 jan 2014.

BAHIA. Leis, etc. Decreto Estadual 14457 de 03 de maio de 2013. Aprova a Política Estadual da Atenção Básica. Diário Oficial da Bahia, Salvador, v.43, n. 21.130-21.131, 4-5 maio de 2013. Disponível em: < http://www.saude.ba.gov.br/ dab/PEAB_publicada.pdf>. Acesso em: 17 maio 2014.

BRASIL. Ministério da Saúde. Secretaria de Atenção à Saúde. Núcleo Técnico da Política Nacional de Humanização. Acolhimento nas práticas de produção de saúde. 2. ed. Brasília: Ministério da Saúde, 2008.

CAMPOS, G.W.S. Um Método para Análise e Cogestão de Coletivos: a constituição do sujeito, a produção de valor de uso e a democracia em instituições: o método da roda. 2. ed. São Paulo: Hucitec, 2005.

OLIVEIRA, Gustavo Nunes. Devir apoiador: uma cartografia da função apoio. Campinas: 2011. Tese (Doutorado em Saúde Coletiva) Universidade Estadual de Campinas, Faculdade de Ciências Médicas, Campinas, 2011.

TESTA, M. Pensar en salud. 3. Ed. Bueno Aires: Lugar Editorial, 2004.

VASCONCELOS, Michele de Freitas Faria de; MORSCHEL, Aline. O apoio institucional e a produção de redes: do desassossego dos mapas vigentes na Saúde Coletiva.
Interface (Botucatu), Botucatu, v. 13, supl. 1, p. 729-38, 2009. Disponívelem <http://www.scielo.br/scielo.php?script=sci_ arttext\&pid=S1414-32832009000500024\&Ing=en\&nrm=i so>. Acesso em 18/05/ 2014. 


\section{Parte III}

\section{O processo de trabalho do Apoiador}




\title{
O Apoio Institucional temperado com música
}

\author{
Nilma Lima dos Santos
}

Ao longo da história, o indivíduo vem criando formas diferentes para expressar ideias, sentimentos, imagens, estabelecendo uma verdadeira comunicação, tendo como exemplo a música. E no cotidiano da vida, nele compreendendo o trabalho, o que seria a música? A música passa a ser o animador da vida, a ligação da arte, da criação com a realidade vivida. Nesse contexto, esse texto tem por objetivo construir uma ligação entre algumas músicas e o Apoio Institucional, entendendo o primeiro como uma construção artística para expressar elementos da realidade e o segundo como um método de organização da gestão em saúde que visa à produção de espaços colegiados de gestão, onde grupos organizados analisam, definem tarefas e elaboram projetos de intervenção sobre suas distintas realidades (CAMPOS, 2000).

A escolha da música como elemento de diálogo para a produção do texto foi motivada em algo descrito pelo escritor Rubem Alves. Recentemente o autor escreveu sobre as pimentas para provocar um incêndio, -não é preciso fogo $\neg$ referindo que há ideias que se assemelham a pimentas e provocam fogo no pensamento (ALVES, 2012). 
Concordando com sua afirmação, se existe uma "pimenta" que provoca em mim as mais diversas ideias, essa "pimenta" chama-se música. Gosto delas, de estar com elas, de apreciá-las, de temperar minha vida com as músicas que passeiam em minha mente. No trabalho, como o som das músicas não ressoavam no espaço, elas ressoavam em meu pensamento. Assim, quando recebi o convite para escrever sobre minhas vivências em Apoio Institucional, pensei que não haveria nada melhor do que escrevê-las temperadas com música.

Com base na Política Estadual da Atenção Básica da Bahia (Decreto Estadual 14.457 de 03 de maio de 2013), - Apoio Institucional é entendido como prática de gestão que reformula o modo tradicional de se fazer coordenação, planejamento, supervisão e avaliação em saúde. Tem como diretriz operante a Democracia Institucional e a Autonomia dos Sujeitos, ou seja, se conforma como um modo de agir que busca enfrentar os modelos de gestão verticalizados e autoritários, não produtores de autonomia dos sujeitos e coletivos. Baseia-se na relação horizontal e no princípio da afetação e Educação Permanente e reconhece as especificidades locorregionais $e$ as subjetividades e singularidades presentes nas relações dos indivíduos e coletividades.

Como construção metodológica para esta narrativa considerei as referências ligadas à sociologia da vida cotidiana, defendida por José Machado Pais (2003), entendendo por cotidiano o que se passa quando nada parece se passar. Justifico minha escolha com uma afirmação do autor de que:

Se o cotidiano é o que passa quando nada se passa na vida que escorre, em efervescência invisível, é porque "o que se passa" tem um significado ambíguo próprio do que subitamente se instala na vida, do que nela irrompe como novidade, mas também do que nela flui ou desliza numa transitoriedade que não deixa grandes marcas de visibilidade (PAIS, 2003, p. 28).

Deste modo farei aqui uma correlação das vivências, com uma exposição dos fatos, sem a pretensão da verdade e da certeza, tampouco da ordem cronológica. No entanto, com um compromisso com o relato do caminho, permeado pelas músicas que afloraram em meus pensamentos, numa relação tríplice: a vida cotidiana, a música e o Apoio Institucional, pois o social que se revela pelo cotidiano não segue uma lógica de demonstração, mas de descoberta, na qual a realidade se insinua, indicia, conjectura (PAIS, 2003).

Convido o leitor, então, a cantarolar essas canções, refletindo sobre os traçados do cotidiano que elas evocaram dessa vivência na gestão da Atenção Básica e do Apoio Institucional.

Para começar $\neg$ "Quando eu vim para esse mundo, eu não atinava em nada". ${ }^{1}$

Dizem que "baiano não nasce, estreia"2. Pois bem, minha estreia pelo campo do Apoio Institucional não foi assim tão fácil, cheguei à Gestão Estadual nos idos de 2009. Logo no primeiro dia embarquei em uma viagem de quatorze horas rumo ao Extremo Sul do Estado, para uma agenda ligada ao Curso de Especialização ${ }^{3}$, fundamentado na dimensão pedagógica do Apoio Institucional, ou seja, a partir da prática e das experimentações construir

\footnotetext{
${ }^{1}$ Trecho da música "Modinha para Gabriela" $\neg$ Dorival Caymmi

2 Expressão popular na Bahia, cuja autoria é atribuída ao cantor e compositor Dorival Caymmi.

${ }^{3}$ Os Cursos de Especialização em Saúde da Família e de Especialização em Gestão da Atenção Básica ambos com Ênfase em Implantação de Linhas de Cuidado foram uma oferta da Diretoria de Atenção Básica da Secretaria da Saúde do Estado da Bahia entre os anos de 2009 e 2010 para qualificação de profissionais e gestores da Atenção Básica das 28 sedes de microrregião no estado da Bahia.
} 
conhecimentos e entendimentos acerca da situação vivenciada, seus problemas e soluções. Nesse dia aprendi dois preceitos básicos do Apoio: "(...)minha vida é andar por esse pais"4 e que tudo se constrói em agenda. Na verdade existia um terceiro, meu vocabulário iria aumentar.

Aquilo que se chamava de agenda era a possibilidade de entregar-se à região, ou seja, toda organização que envolvia a marcação de viagem, seu deslocamento, pautas a serem discutidas a cada dia, reuniões, encontros e articulações que precisavam ser traçadas para dar conta do espaço de diálogo para apresentar projetos da Gestão Estadual, fazer leituras da realidade das gestões municipais e das diferentes Regiões de Saúde: era, de fato, o "sentir-se Apoiador".

"Larga de ser boba e vem comigo, existe um mundo novo eu quero te mostrar, que não se aprende em nenhum livro, basta ter coragem pra se libertar, viver. ${ }^{5 \prime}$

Naquela agenda no Extremo Sul ainda um tanto zonza da viagem, aportei em meio a uma discussão com a turma de especializandos do Curso de Especialização ofertado pela Gestão Estadual para qualificação de gestores municipais e regionais, além dos trabalhadores da Atenção Básica dos municípios sede de Região de Saúde. A discussão versava sobre Acolhimento Pedagógico, Núcleo Microrregional de Educação Permanente, Orientador de Aprendizagem de Campo (BAHIA. Leis, etc., 2013). Um elenco de nomes novos e carregados de sentidos, todos muito voltados à experiência de desenvolvimento de ações para a Atenção Básica.

Numa lógica de formação, o Curso de Especialização reunia duas turmas em qualificação (gestores da Atenção Básica e trabalhadores das Unidades de Saúde da Família).

\footnotetext{
${ }^{4}$ Trecho da música "A vida de viajante" $\neg$ Luiz Gonzaga, Hervê Cordovil. ${ }^{5}$ Trecho da música "Na sombra de uma árvore" - Hyldon.
}

Por si só, essa reunião de atores já buscava concentrar uma potência, pois, ao reunir trabalhadores e gestores em um processo de formação, a proposta era que as demandas das equipes de Saúde da Família pudessem ser discutidas a partir das motivações e temáticas apresentadas em cada módulo.

Pode-se analisar que a união de gestores e trabalhadores no espaço de formação reconhece que as rotas do cotidiano são denunciadoras dos múltiplos meandros da vida social (PAIS, 2003). Assim, a cada módulo temático era proposta a construção de uma tarefa práxica, onde a prática era a base para a sua construção e que estava voltada à reorganização do processo de trabalho dos profissionais das equipes de Saúde da Família, baseado no acolhimento, e a uma outra lógica de organização de gestão mais transparente, cogestora, onde os entes instituiriam relações baseadas na corresponsabilização e no Apoio às equipes. Ou seja, a partir da prática, o cotidiano era utilizado como revelador de determinados processos do funcionamento das Unidades de Saúde e da Gestão, bem como revelador das transformações possíveis e dos conflitos que os atravessavam (PAIS, 2003).

Nesses espaços de Educação Permanente, cada ator poderia dizer, assim como os Novos Baianos "vou mostrando como sou e vou sendo como posso, jogando meu corpo no mundo, andando por todos os cantos e pela lei natural dos encontros eu deixo e recebo um tanto"7. Os conflitos e possibilidades de gestores e trabalhadores desvelavam-se, ou seja, revelavam-se ${ }^{8}$ na mesa/roda de troca. Muito do que se construía esbarrava nas

${ }^{6}$ Conjunto musical nascido na Bahia ativo em seu auge entre os anos de 1969 e 1979.

7 Trecho da música "Mistério do Planeta" - Luis Galvão, Moraes Moreira.

8 Trabalhei aqui com o sentido de desvelar como tornar conhecido, fazer com que seja revelado, inspirada pelo autor da Sociologia do Cotidiano, José Machado Pais (data). 
contingências das intencionalidades de administradores e projetos políticos diversos, que por vezes não consideravam a realidade e demandas dos usuários, tampouco a análise dos trabalhadores que vivenciavam as práticas cotidianas de cuidado e gestão microrrelacional da saúde dos usuários sob sua responsabilidade.

Outro desafio apontado por esse modelo de formação foi unir um coletivo de gestores e trabalhadores com vínculos trabalhistas fragilizados, visando ao estreitamento dos vínculos, a uma melhor identificação dos problemas e atuação nas priorizações desse grupo para qualificação do processo de trabalho na Atenção Básica, tendo por consequência a contribuição para as condições de saúde da população.

Tua flor me deu alguém pra amar e quanto a mim? Você assim e eu, por final sem meu lugar e eu tive tudo sem saber quem era $e u^{9}$.

A cada mediação enquanto Orientadora de Aprendizagem de Campo a realidade das equipes de Saúde da Família e da Gestão se revelava, e as dificuldades para o Apoio também floresciam. Surgia sempre a questão: como aquelas propostas e discussões, e toda a construção de tarefas poderiam se tornar prática? Como transformar o cotidiano? Como operar a mudança diante da baixa governabilidade do grupo frente ao projeto de saúde do Município?

Onde estava a prioridade para a organização da Atenção Básica? Quais as limitações do Apoio Institucional para seu fortalecimento? Falava-se da qualificação da Atenção Básica, de reorganização do processo de trabalho de gestores e trabalhadores, daquilo que fugia da governabilidade dos Apoiadores Institucionais ligados a Gestão Estadual, estando as ofertas no campo da ${ }^{9}$ Trecho da música "A flor" - Marcelo Camelo e Rodrigo Amarante. organização, vinculação e reconhecimento.

Leituras técnicas e políticas dos espaços de decisão mostraram-se uma ferramenta crucial, ou seja, decisiva para entender sobre a existência ou não de projetos de saúde para a população. Defender a "bandeira" ${ }^{10}$ de uma Atenção Básica resolutiva, acolhedora, vinculada e territorializada, esbarrava em processo de gestão, por questões estruturais e operativas.

Muito já se havia feito. No entanto, onde estavam o empoderamento, as práticas libertadoras e o projeto de autonomia dos sujeitos? Por vezes me reconhecia na frase do reggae que diz "a consciência do povo daqui é o medo dos homens de lá, sabedoria do povo daqui, é o medo dos homens de lá"11. Ou seja, não visualizava nas discussões/ agendas propostas que visassem a esse olhar e a essa produção de sentidos, àqueles que são o alvo e a razão de ser do trabalho na Atenção Básica (usuários do sistema de saúde).

Busca-se que a Atenção Básica seja coordenadora do cuidado ao sujeito inteiro (mesmo que em pedaços devido ao sofrimento), reconhecendo-o como um ser integral, morador de uma localidade/território com suas lógicas próprias e diferenciadas de organização, onde cada indivíduo constrói seus itinerários. Sem ater-me ao cuidado ao sofrimento, questionava como a Atenção Básica valorizava o sujeito, usuário do serviço, com sua história, seus saberes e poderes com escalas e reconhecimentos diferentes? Como apoiar a Gestão Municipal nesse sentido? Como incentivar relações solidárias entre os gestores na Região de Saúde?

${ }^{10}$ Utilizo aqui a palavra "bandeira" no sentido de "Ideia que serve de guia ou símbolo a uma cruzada, teoria, partido etc." (Dicionário MichaellisDicionário de Português on line. http://michaelis.uol.com.br/moderno/ portugues/index.php?lingua=portugues-portugues\&palavra=bandeira) ${ }^{11}$ Deixa o menino jogar - Natiruts. 
Um dos pressupostos do Apoio Institucional, nesse sentido, é que a Atenção Básica deve atuar no território, pois a partir dele seria possível, encontrar, perceber, se olhar, se entender, ou seja, criar vínculo e atender às demandas locais.

Apenas por meio da leitura e análise do território seria possível fazer girar a mola que aciona a rede, no sentido de coordenar o cuidado, ou seja, considerando a realidade individual e coletiva, os determinantes de saúde daquela localidade, os modos de vida dos diversos sujeitos, para, a partir daí, apontar quais os cuidados que se fazem necessários.

No entanto, muitos gestores municipais não partiam de tal análise sobre o território para organizar as ações de saúde, recorrendo ao discurso que a Atenção Básica era muito cara e subfinanciada. Seus projetos de gestão da saúde concentravam-se na oferta de hospitais. As vagas para Serviços de Apoio ao Diagnóstico e Terapia (SADT) e consulta especializada viravam "moeda de troca", diante dos munícipes. As ações de promoção à saúde e prevenção aos agravos, pilares da Atenção Básica, tornavam-se incipientes diante das ações curativas.

Os tempos passaram a ser difíceis. O encanto da discussão se perdia a cada emoção frustrada de não ver a mudança que se esperava. Por vezes lembrava que "quem cala sobre teu corpo consente na tua morte, talhada a ferro e fogo nas profundezas do corte ${ }^{\prime 12}$. Para combater tal sentimento e vivenciar o silenciamento capaz de paralisar, os espaços de troca entre os Apoiadores passaram a alimentar as suas forças, a identificar outras estratégias de negociações dentro dos limites de governabilidade de cada Apoiador, e, dentro do possível no campo de atuação de cada ator, regional, municipal ou estadual.

${ }^{12}$ Trecho da música "Menino" - Milton Nascimento, Ronaldo Bastos
Tem dias que a gente se sente como quem partiu ou morreu, a gente estancou de repente ou foi o mundo então que cresceu. $^{13}$

No fundo sei que o ser Apoiador adquire corpo em mim como um exercício diário, onde o cotidiano se insinua, e se reparte, onde seus símbolos e significados se misturam. Estou neste Apoio, numa realidade de uma Atenção Básica que se desvela das mais diferentes formas, onde as apostas são cotidianas. A teoria revela as experiências e as formas possíveis, muito dessa formação vem da leitura de uma construção teórica em defesa da vida, de outras experiências sobre Apoio Institucional, gestão, direitos dos usuários, Educação Popular ou relatos como alguém pode chegar a ler esta narrativa que escrevo.

Diante de tudo que se insinua no cotidiano do Apoio Institucional, a pimenta-música que me permeia é intitulada "Alucinação", de Belchior que me diz:

Eu não estou interessado em nenhuma teoria, nem nessas coisas do oriente, romances astrais. A minha alucinação é suportar o dia-a-dia e meu delírio é a experiência com coisas reais (...) Mas eu não estou interessado em nenhuma teoria, em nenhuma fantasia, nem no algo mais, longe o profeta do terror que a laranja mecânica anuncia, amar e mudar as coisas me interessa mais. ${ }^{14}$

Essa "pimenta" recorda-me que a tarefa é práxica, que é sobre a prática que o Apoio é operado, mas, parafraseando Chales Garvin, "aí já é uma outra história". ${ }^{15}$

Considero que esse relato, por meio das músicas e

\footnotetext{
13 Trecho da música "Roda Viva" - Chico Buarque.

14 Trecho da música "Alucinação" - Belchior.

15 Frase utilizada no encerramento do programa "O Som do Vinil", exibido pelo Canal Brasil.
} 
reflexões que se apresentaram aqui, deve atuar como um convite para que novos textos sejam escritos, uma vez que o Apoio Institucional como método de organização da gestão por meio de espaços colegiados e da autonomia dos sujeitos vai produzir diversas formas de relação entre seus atores, a depender das relações traçadas, do contexto, da conjuntura e da governabilidade de cada um dos envolvidos. Muitas e outras vivências podem ser contadas e irão contribuir para um melhor entendimento de como o Apoio Institucional opera no cotidiano da gestão do Sistema de Saúde.

\title{
Referências
}

\section{Os sentidos de uma experiência ao habitar o território no Apoio Institucional descentralizado}

\author{
Américo Yuiti Mori
}

ALVES, R. Pimentas para provocar um incêndio, não é preciso fogo. São Paulo: Planeta, 2012.

BAHIA. Leis, etc. Decreto Estadual 14457 de 03 de maio de 2013. Aprova a Política Estadual da Atenção Básica. Diário Oficial da Bahia, Salvador, v.43, n. 21.130-21.131, 4-5 maio de 2013. Disponível em: < http://www.saude.ba.gov.br/ dab/PEAB_publicada.pdf $>$. Acesso em: 17 maio 2014.

CAMPOS, G. W. S. Um método para análise e cogestão de coletivos: a constituição do sujeito, a produção de valor de uso e a democracia em instituições: o método da roda. 2.ed. São Paulo: Ed. Hucitec, 2000.

DICIONÁRIO Michaellis . Dicionário de Português on line. Disponível em http://michaelis.uol.com.br/ moderno/portugues/index.php?lingua=portuguesportugues\&palavra=bandeira. Acesso em: maio de 2014.

PAIS, J. M. Vida Cotidiana - Enigmas e revelações. São Paulo: Cortez, 2003.

\author{
Aos encontros proporcionados pelo território \\ habitado, lugar do trabalho na Função Apoio e \\ lugar onde acontece a vida.
}

\section{Para começar a conversa chamo a atenção que...}

Este texto foi produzido a partir da exploração dos sentidos e subjetivação de minha experiência profissional, ao se constituir como experiência de estar no mundo. Faz imersão no olhar, na escuta, reflexões e principalmente caminhos trilhados em pouco mais de um ano de trabalho como Apoiador e vivência no território que tive a oportunidade de habitar. Relata a experiência do autor como sanitarista da carreira da Fundação Estatal Saúde 
da Família (FESF-SUS), no período de novembro de 2011 a janeiro de 2013, exercendo a Função Apoio no cargo de Assistente de Apoio Institucional, lotado na sede e com atuação descentralizada. O relato teve como fonte os registros dos relatórios de "visita de apoio" e "diário de campo", este último organizado em formato de portfolio, além do bom e velho bloquinho de anotações, o qual tinha o tamanho exato de um bolso, e serviu para registro de impressões, pensamentos, desenhos, sentimentos, ideias e devaneios.

$O$ relato se mistura com movimentos da vida, do ir e vir no território habitado e no território referência para o trabalho. A escolha deste tipo de narrativa evoca a reflexão sobre o quanto o trabalho invade a nossa vida. Então, porque não deixar a vida ser contemplada pelas condições do trabalho? Além de o trabalho servir para criar nossas bases materiais, no caso do trabalhador-militante, se apagam os limites entre um e outro, e são projetados no trabalho muitos sentidos da vida. Ao se constituir este tipo de trabalhador desejante, se espreita o sonho de um projeto de sociedade, no qual fazemos o recorte da saúde, mais precisamente da significação dos princípios do Sistema Único de Saúde (SUS) no funcionamento dos serviços de saúde e modo de produção do cuidado.

À medida que o trabalho invade a vida, trata-se de um movimento lógico o caminho inverso; a vida logo invade com toda a sua intensidade o trabalho. Assim, pensar acesso a coisas, lugares e pessoas, ajuda a pensar acesso aos serviços de saúde. Diria que viver e sentir a dificuldade de acesso ajuda a se identificar (criar empatia) com as necessidades de saúde das pessoas usuárias do sistema, gera incômodo no Apoiador e necessidade de se criar mecanismos capazes de produzir cenários de mudanças.

Com este entendimento e por terem sido apagados os limites entre o trabalho e a vida cotidiana, é que misturo neste relato a vivência de me constituir como Apoiador regionalizado (descentralizado) e a experiência de construir uma base para a vida na Chapada Diamantina, em um município do interior da Bahia em que fiz a opção de viver. Por isso, embora o texto contenha imagens e reflexões produzidas a partir da vivência institucional em um coletivo, o que socializo são afetações dos movimentos da vida.

\section{O território do trabalho: o primeiro passo da caminhada foi criar um mapa de onde se partia $^{1}$}

Na convocação, como sanitarista, por concurso público da FESF-SUS, apenas me senti mobilizado a abraçar a nova proposta de trabalho quando a perspicaz Coordenadora do Apoio desta instituição captou o meu desejo de experimentar a vida na Chapada Diamantina/Bahia. Assim, a minha escolha de viver no interior é que determinou o meu contato com a experiência do Apoio descentralizado. Fui me fazendo sujeito ao trocar com a Instituição o meu desejo e condições materiais para a vida, com a missão de colaborar com o desenvolvimento dessa estratégia.

No fim do ano de 2011, o cenário institucional era de necessidade de consolidação dos serviços de atenção à saúde para o avanço da estratégia de desprecarização dos vínculos dos profissionais e desenvolvimento da carreira para a Saúde da Família no Estado da Bahia. A FESF-SUS, criada em 2009 por 69 municípios constituidores e com a

${ }^{1}$ Aqui foi proposital o uso da expressão "um mapa de onde se partia". Pois geralmente se tem mapas para chegar a algum lugar, para se traçar um caminho. A intenção foi brincar com o termo mapa no uso que é feito por Merhy (2002) quando discute cartografia. Então, mapa de onde se partia significa análise/diagnóstico. 
indução do Estado, concebida para ofertar uma alternativa pública para a desprecarização e formação de uma carreira para os profissionais da Saúde da Família, passando esta fundação a operar por meio de contrato de gestão com os municípios mediante contratualização da prestação de serviços para provimento destes trabalhadores.

Nacionalmente, o Ministério da Saúde (MS) fazia a indução para a adesão ao Programa de Melhoria do Acesso e da Qualidade da Atenção Básica (PMAQ-AB), e sinalizava uma recomposição do financiamento da Atenção Básica mediante resultados alcançados no desenvolvimento do processo de trabalho das equipes e da gestão. O PMAQ-AB adota como um dos eixos estruturantes o Apoio Institucional induzindo a implantação da sua lógica de gestão junto às secretarias municipais e estaduais de saúde, enquanto ferramenta para instituir processos de negociação de metas, desenvolvimento das ações para melhoria do acesso e da qualidade dos serviços e, alcance de resultados mediante avaliação e monitoramento. (BRASIL. Ministério da Saúde. Secretaria de Atenção à Saúde, 2011).

A abordagem do Apoio Institucional, o qual se trata de um modo de fazer gestão, valoriza o acolhimento das dificuldades enfrentadas no cotidiano dos serviços, que segundo Campos (2008), "trata-se de uma metodologia que busca construir condições favoráveis para a reflexão sobre a atuação dos sujeitos no mundo" e reconhece que os efeitos de uma gestão compartilhada podem acontecer através de espaços de disputa entre projetos e deliberações; espaço de análise institucional e de emergência das subjetividades, de diferentes visões de mundo; Educação Permanente e como instância da gestão propriamente dita.

Em seu trabalho, Débora Bertussi (2010) tece a ideia de que o projeto de saúde é também disputado no espaço da Micropolítica e o Apoio Institucional e Matricial são dispositivos para articular a rede de serviços a partir da mobilização do potencial transformador dos sujeitos. Como dispositivo metodológico aproxima a gestão dos territórios onde se reproduzem as práticas de saúde, coloca em análise a multiplicidade de atores e a circulação de afetos, traz para a arena de negociação/pactuação os desejos e interesses públicos e privados, produz um agir em saúde principalmente a partir de tecnologias leves e leve-duras, colocando na centralidade a necessidade do usuário e destacando o protagonismo dos atores.

Diante deste cenário a Coordenação de Contratualização e Apoio Institucional da FESF-SUS fez um arranjo da sua equipe, destacando oito trabalhadores da carreira (sanitaristas ou trabalhadores da assistência em função estratégica de gestão) para serem referencias regionalizadas no exercício da Função Apoio. Entre as missões dessa equipe estava o apoio para desenvolvimento da carreira e serviços FESF-SUS, e, atuação junto com a Gestão Municipal e equipes de Saúde da Família para desenvolvimento das ações propostas pela metodologia do $P M A Q-A B$.

Nessa perspectiva foi proposto o Apoio Regionalizado (descentralizado) da FESF-SUS, que inicialmente contou com cinco dos oito Apoiadores lotados na sede e atuando de forma descentralizada. Na Função Apoio eu estaria residindo no território, uma vez que a descentralização se justificava pela quantidade de municípios e serviços contratualizados, e a necessidade de redução de custos. Além da proposta me proporcionar a oportunidade de morar na Chapada Diamantina, fiquei atraído com a perspectiva de maior proximidade das equipes de gestão municipal e dos trabalhadores da equipe de Saúde da Família, aquilo que um colega costumava chamar de estar mais próximo do "chão da fábrica". 
A equipe contava com quatro gerentes (Gerente de Apoio Matricial, Gerente de Atenção à Saúde, Gerente de Gestão de Contratos e Gerente de Contratualização e Apoio), além dos oito Apoiadores e Coordenadora. Esses gerentes ficavam lotados na sede e tinham o papel de apoio à coordenação da equipe, sendo referências para o acompanhamento e supervisão das ações no território e matriciamento das demandas do Apoiador.

O território ao qual eu estava destinado a ser referência no Apoio Regionalizado foi composto por três municípios da Chapada Diamantina e dois municípios do território da Região de Irecê, cabendo-me apoiar e acompanhar em parceria com as gestões municipais o desenvolvimento de quinze equipes de Saúde da Família e vinte e nove trabalhadores da carreira que estavam distribuídos entre esses cinco municípios.

A minha chegada à fundação FESF-SUS em novembro de 2011 foi marcada pela constituição dessa nova equipe de Apoiadores, mesclando trabalhadores que já estavam atuando como Apoiadores da coordenação e outros que estavam chegando como eu. No primeiro mês foi realizado um intenso trabalho de acolhimento, com imersão na compreensão do projeto de desprecarização e carreira da Saúde da Família da FESF-SUS e ferramentas para operar o seu sistema de gestão por resultados.

Esse processo se traduziu na incorporação e revisão de conteúdos para operar o Sistema FESF-SUS. A engrenagem desse sistema é própria da fundação e compreende a Carreira, Gestão por Resultados, Educação Permanente e Apoio Institucional. Os conteúdos-ferramentas foram apresentados pelas coordenações das respectivas diretorias responsáveis por cada um dos componentes do sistema. Na perspectiva do trabalho a ser desenvolvido existia a necessidade de investimento no conjunto dos trabalhadores para operarem o sistema, assimilando a missão institucional. Procurei então colaborar no debate da organização do processo de trabalho, mas a trama institucional composta por fluxos complexos de processos estruturados e a fragmentação entre as diretorias me pareceu cooptar a subjetivação do Apoio frente à burocracia institucional.

Logo percebi que o lugar do "entre" do Apoiador não residia em incorporar a organização da estrutura institucional e sim criar mapas dos fluxos institucionais para fazer circular as ofertas e demandas do Apoio, e nessa perspectiva ficava cada vez mais ansioso em "pisar" no território onde acontece a inserção dos trabalhadores da Saúde da Família.

\section{A constituição do coletivo a partir da organização do seu processo de trabalho}

Nesse período de composição da equipe de trabalho foram sendo estabelecidos pactos e fluxos entre a coordenação e o grupo de Apoiadores, para orientar o processo de trabalho e sua missão institucional. Isso se deu através de oficinas de trabalho que buscavam a produção do coletivo e a definição da sua forma e organização. Esse processo deu origem à "agenda típica" do Apoiador, que definiu alguns arranjos para orientação do trabalho e Educação Permanente.

Dentre os arranjos, destacam-se com seus respectivos objetivos:

- Encontro Semanal: apelidado de "esquente"; ocorria todo início da manhã das segundas-feiras na sede da FESF- 
SUS e com participação dos Apoiadores descentralizados por meio de chat ou videoconferência. O objetivo era a atualização das pautas institucionais e do contexto da Atenção Básica. A maior dificuldade para o desenvolvimento do arranjo de encontro eram problemas com a conectividade (no caso para a participação dos descentralizados) e a quantidade de demandas que transformava o espaço de informes e organização da agenda em discussão de pautas;

- Encontro Mensal: o encontro mensal ocorria em dois ou três dias, funcionava em formato de oficinas e buscava proporcionar espaço de Educação Permanente para formação dos Apoiadores a partir de suas vivências no território. A agenda inicial de encontros foi bastante rica para a produção do coletivo e elaboração de planejamento e estratégias com base em vivência no território. A partir do segundo semestre de 2012 houve dificuldade de manter o espaço com essas características devido à agenda institucional que repercutia em dificuldade de compatibilidade entre as pautas do território e pautas definidas pelo grupo dirigente da Instituição, participação efetiva dos atores, dinâmica das relações contratuais com os municípios e movimento de reforma administrativa da FESF-SUS;

- Registro do trabalho e supervisão do Apoio: para acompanhamento pedagógico e da gestão do trabalho foram estabelecidos relatórios de "visita de Apoio" e posteriormente relatório semanal, todos estes, compondo o registro das atividades, com a pretensão também de subsidiar o acompanhamento da coordenação e gerentes;

- Processo de comunicação e acompanhamento: além de e-mail e telefone, foi orientado prioritariamente o processo de comunicação via plataforma moodle. Nesta plataforma foi criado o "espaço do Apoiador" para encaminhamento dos relatórios de atividades semanais e produção de diálogo e troca de experiência entre as equipes com auxílio de fóruns de debates. Os gerentes se dividiam como referências para acompanhamento dos Apoiadores e matriciamento de determinados temas. Com isso se incubiam em provocar e subsidiar algumas discussões na plataforma, por ocasião da abertura desses fóruns.

Abaixo, destaco alguns dos itens elaborados por esse coletivo, que orientaram a minha atuação no trabalho do Apoio Institucional descentralizado:

\section{A proposta do Apoio regionalizado surgiu da} necessidade de:

- Estar mais próximo dos municípios para favorecer o vínculo e agilidade na resposta às demandas;

- Reduzir custos e tempo com deslocamento dos Apoiadores;

- Estar mais próximo das equipes e gestores municipais na perspectiva de fortalecer a cogestão do sistema FESFSUS;

- Apoiar os municípios distantes da sede e com dificuldade de acesso. Ter um Apoiador descentralizado favoreceria esse contato uma vez que a FESF-SUS não possui uma estrutura descentralizada como a Secretaria da Saúde do Estado da Bahia (SESAB), por meio das Diretorias Regionais de Saúde.

\section{Características do Apoio Regionalizado:}

- Dinamicidade e flexibilidade no desempenho de suas funções;

- O Apoio estava em momento de reorganização interna pelo conjunto de seus trabalhadores e conformação 
da oferta de serviços que precisava consolidar resultados. Assim, o desenho se daria a partir da dinâmica do território e a demanda de execução dos serviços.

\section{Apoio Regionalizado e os fluxos institucionais:}

- O processo de comunicação entre os Apoiadores descentralizados e sede deveria ser constante e principalmente por meio virtual. Foram sendo criados instrumentos e estratégias para acompanhamento e supervisão do Apoio, como relatório de visita e relatório semanal de atividades, reunião virtual semanal e reunião mensal na sede, com objetivo de Supervisão e Educação Permanente;

- $O$ acesso às informações seria demandado de acordo com a necessidade dos atores. A informação é livre pelo princípio da transparência da FESF-SUS, devendo o seu uso e cuidado ser responsabilidade de todos;

- Os Apoiadores teriam o Gerente de Apoio Matricial, Gerente de Atenção à Saúde, Gerente de Gestão de Contratos e Gerente de Contratualização e Apoio como referência para acompanhamento de suas ações, e matriciamento das demandas oriundas do território.

Definido o roteiro, o segundo passo foi criar um mapa para chegar ao território de Apoio

Em dezembro de 2011, ainda na sede da FESFSUS, em Salvador, quando preparava a minha entrada no território, debrucei-me sobre a tarefa de construir uma análise de cada um dos cinco municípios que iria apoiar.
Fui então compondo alguns mapas a partir das seguintes informações:

- Indicadores de saúde com interface com a Atenção Básica (análise de dados do Caderno de Avaliação e Monitoramento da Atenção Básica que estava sendo desenvolvido pela DAB/SESAB e consulta ao DATASUS/ Tabnet);

- Rede de Atenção à Saúde e mapa de adesão aos programas do Ministério da Saúde com o uso do site da Sala de Apoio à Gestão Estratégica do MS;

- Análise da governança para o projeto FESF-SUS mapa construído pela coordenação e Apoiadores em sua interface com território. Envolvia a análise da capacidade de governo e orientação política da prefeitura, capacidade técnica e envolvimento da gestão municipal com o projeto de desprecarização e carreira da FESF-SUS, serviços contratualizados e em execução junto ao município;

- Histórico das ações do Apoio desenvolvidas junto com os municípios pela FESF-SUS (realizado por meio de conversas com Apoiadores que me antecederam e consulta ao blog do Apoio; nele são registradas todas as "visitas de Apoio" realizadas aos municípios);

- Levantamento das distâncias, formas de deslocamento e custos, para elaboração de itinerário, e planejamento de "visitas de Apoio".

As atividades orientadas pela coordenação ainda compunham estudo sobre o Apoio Institucional, PMAQ e a elaboração de instrumentos e metodologias para apoiar o desenvolvimento das ações.

Nesse período realizei as primeiras agendas de visita com Apoiadores que já estavam atuando na antiga conformação da equipe da coordenação do Apoio. Eles 
já tinham algum vínculo com os municípios e ajudaram na transição da referência de Apoiador. Fui apresentado como nova referência juntamente com a proposta do Apoio descentralizado e a missão de facilitar a aplicação das ferramentas do Sistema FESF-SUS no contexto do PMAQ$A B$.

No início de 2012, eu dispunha de: imagem inicial dos territórios; os contatos; como chegar aos territórios; qual a tarefa institucional; o discurso pautado pelos slides e a "mochila" cheia de instrumentos e ferramentas do Sistema FESF-SUS. Faltando apenas, lançar-me sobre o território, com o desafio de habitá-lo.

Esse período coincidiu com a minha mudança para a região; os mapas criados ajudavam-me não só a territorializar o processo de trabalho, mas tornavamse úteis para a vida. As primeiras agendas no território também serviram para que eu me situasse enquanto um estranho naquele lugar, encaradas por mim como etapa de um processo de acomodação. Significava o estranhamento como um momento de reconhecer aquilo que era diferente do que vivi morando em São Paulo e depois em Salvador, e, consequentemente, a identificação de coisas que buscava para ser um novo cotidiano de vida.

As primeiras viagens de Apoio serviram também para explorar novas experiências, ia experimentando aos poucos novos lugares e apesar de uma pré-definição de morar em uma cidade da Chapada Diamantina, ia conhecendo e escolhendo o meu novo lugar de moradia.
Mapas servem para traçar o caminho e localizar; já a caminhada é outra coisa...

Em minha chegada à região, eu já tinha algumas imagens e referências do período (2009 a 2011) em que fui Apoiador das Macrorregiões Centro-Leste e Centro-Norte pela Diretoria de Atenção Básica da Secretaria da Saúde do Estado da Bahia (DAB/SAIS/SESAB ${ }^{2}$ ). Assim, sabia que as Diretorias Regionais de Saúde eram atores importantes no processo de descentralização das políticas de saúde e atuação junto aos municípios. Logo, procurei me aproximar para estabelecer uma relação de cooperação e para potencializar as agendas comuns. Com as tentativas percebi que havia papel determinante do nível central das duas instituições (SESAB e FESF-SUS) na conformação de agendas comuns, e que esse tipo de atuação se faria com o tempo, a partir da produção de vínculo entre os trabalhadores que atuam no território e a articulação de projetos comuns.

Com vinte e nove trabalhadores para serem acompanhados em cinco municípios, os quais estavam distribuídos em duas Regiões de Saúde, foi um desafio colocar em prática a agenda planejada. Além da dificuldade de estruturar a agenda e negociá-la com os atores era necessário o deslocamento entre os municípios por meio do transporte coletivo. Isso significou identificar não só empresas e horários dos ônibus, escassos e em péssimas condições, mas também perceber o fluxo das pessoas. Geralmente é feito o deslocamento dos municípios para o município sede da Região de Saúde, para Salvador Capital e vice-versa. Quase não há transporte para deslocamento entre os outros municípios dentro da Região.

${ }^{2}$ A Diretoria de Atenção Básica compõe o organograma estrutural e funcional da Superintendência de Atenção Integral à Saúde (SAIS) da Secretaria da Saúde do Estado da Bahia. 
O desafio do deslocamento foi enfrentado com ajuda de taxistas e motoristas que circulam na região, trabalhadores das DIRES, agentes rodoviários, motoristas de transporte clandestino, comerciantes, etc. Os encontros e conversas aleatórias tornavam-se arranjos, onde eu conhecia pessoas, deparando-me com informações que ajudavam o meu entendimento sobre o território para o desenvolvimento do trabalho.

Em curto espaço de tempo, fui me dando conta que esses mapas para o desenvolvimento do trabalho, assim como os lugares para comer, dormir e formas de deslocamento entre os cinco municípios, me ajudavam a criar familiaridade com a região. A experiência cartográfica passou a ser um jeito de conversar com as pessoas e experimentar a vida naquela região.

Deslocamento de Irecê para Uibaí, cerca de trinte e três $\mathrm{Km}$, o que leva mais ou menos vinte minutos de carro. Pista simples e sem acostamento, asfalto irregular e com muitos buracos. O motorista disse que a internet e telefone celular só funcionam da operadora $\mathrm{X}^{3}$.

Outros elementos foram agregados à busca exploratória por informações tão básicas para o desenvolvimento do meu trabalho. Assim, os encontros com pessoas do cotidiano foram subsidiando minha análise sobre acesso e qualidade dos serviços de saúde, bem como seus itinerários terapêuticos, os nichos de poder da região e suas relações, o que me ajudou a compor cenário e correlação de forças do jogo eleitoral ocorrido no fim do ano de 2012.

Habitar aquele território me oportunizava encontros que se somavam ao olhar do gestor e trabalhador da saúde, colocando em conflito e análise as ações desenvolvidas ${ }^{3}$ Trecho retirado do Bloco de Anotações pessoais. na produção da saúde. Fui percebendo que não bastava a representação de objetos (fragmentos da realidade), era necessário acompanhar processos, ou seja, como a vida acontece e as forças que agem sobre ela. (PASSOS; KASTRUP; ESCÓSSIA, 2010)

As experiências no território aconteciam e no trabalho do Apoio os instrumentos para acompanhamento das ações e Educação Permanente da equipe, listados logo acima, não pareciam dialogar com as minhas necessidades. Sentia que me faltavam ferramentas para compreender e elaborar o processo que estava vivenciando.

Sexta-feira, tarde do dia, quase finalzinho do dia. A respiração profunda é cortada por um suspiro que anuncia o pensamento: Aqui tudo chama atenção; assim é tudo tão intenso. Fiquei pensando que é necessário escrever. Mas escrever sozinho? Escrever essas experiências em um relatório burocrático? Assim é quase que conversar com alguém que não te escuta ${ }^{4}$.

Apenas mais tarde concluí que o processo cartográfico carecia da dinâmica de análise estabelecida nas relações de um coletivo sobre seu objeto de investimento e Apoio. No caso, refiro-me ao coletivo da Equipe de Apoio da FESF -SUS e coletivo de trabalhadores das equipes de saúde e das gestões municipais.

$\mathrm{O}$ trabalho de Apoio às equipes de saúde e gestores municipais foi permeado pela agenda estratégica estabelecida no planejamento da coordenação de Apoio da FESF-SUS. Dentre elas destacavam-se o desenvolvimento das ações do PMAQ-AB e fortalecimento da gestão municipal, para gestão compartilhada do Sistema FESF-SUS.

4 Trecho do bloco de anotações que anunciava reflexão sobre o processo de produção de relatórios de visita e seu valor de uso no matriciamento/supervisão do Apoio. 
Seguiu-se então uma intensa agenda de capacitação das equipes de gestão municipal para o uso do Sistema FESF-SUS e seus instrumentos, bem como a negociação de demandas e compromissos para o desenvolvimento das ações do PMAQ-AB. No geral foram encontradas grandes dificuldades para se concretizar o desenvolvimento das ações de forma compartilhada com os gestores dos cinco municípios apoiados.

Esse contexto aponta algumas dificuldades como, por exemplo, o fato de, a maioria das gestões municipais apresentarem escassos recursos. A Coordenação da Atenção Básica invariavelmente acumula outras funções e possui pouca governabilidade para enfrentar problemas como irregularidade no fornecimento de materiais e insumos ou manutenção das unidades de saúde. Com este cenário, onde havia baixa capacidade técnica e política das gestões, a missão de utilizar o Sistema FESF-SUS e instrumentos do $P M A Q-A B$ para aproximar a gestão do cotidiano das equipes de trabalhadores na perspectiva da gestão do trabalho e Educação Permanente, tornava-se cada vez mais desafiadora.

Por outro lado, a agenda do Apoio da FESF-SUS, em sua missão, estava ancorada no uso de instrumentos para o desenvolvimento da metodologia do PMAQ$A B$ e desenvolvimento da carreira. A incorporação de tecnologias, muitas vezes sobressai como tarefa finalística, quando, na verdade, trata-se de meio para a produção e gestão do cuidado no trabalho em saúde ${ }^{5}$.

\footnotetext{
${ }^{5}$ Os termos instrumentos e tecnologias aqui empregados no contexto da saúde dizem respeito à categoria trabalho abordada na vertente marxista (MARX, 1994). Instrumento refere-se ao emprego do conhecimento do campo científico para mobilização da ação transformadora, através do trabalho, na produção de bens. Tecnologia refere-se a um conceito mais amplo, onde é mobilizado saberes técnicos e relacionais no trabalho em saúde para a produção do cuidado (GONÇALVES, 1994).
}

A tendência de se restringir, modo e instrumentos como finalidade do trabalho, é temerosa, na medida em que a tríplice finalidade das organizações, definida por Campos (2003), aponta para a produção de bens com valor social, reprodução da própria organização e produção de sujeitos implicados. Assim, o objeto de investimento do Apoio não pode se restringir à incorporação de suas ofertas por um determinado coletivo.

Diante do contexto, a estratégia de trabalho foi apostar na formação e fortalecimento de coletivos de gestão municipal da Atenção Básica. Envolvendo o Coordenador de Atenção Básica, outros técnicos da Secretaria Municipal de Saúde e quando possível os trabalhadores das equipes de saúde.

Para esse movimento tentei articular o uso dos instrumentos da Gestão por Resultados e da carreira da FESF. Coincidia nesse período, primeiro semestre 2012, a necessidade de realizar a avaliação anual de desempenho dos trabalhadores FESF-SUS para progressão na carreira, planejamento semestral de ações e resultados, além de estar em curso o Prêmio de Inovação e Qualidade. Essas demandas do Sistema FESF-SUS tentavam ser compatibilizadas com a necessidade de realizar a autoavaliação do PMAQ-AB.

Por isso, utilizando as dimensões da Gestão Municipal e Gestão da Atenção Básica do instrumento de autoavaliação do PMAQ-AB, buscava explicitar quais eram os atores envolvidos com a Gestão da Atenção Básica, mobilizandoos para se aproximarem das equipes de saúde. Assim, a experiência prática do uso dos instrumentos tinha como objetivo gerar a reflexão sobre a organização do processo de trabalho da gestão, e, capacitá-la para o seu uso juntos com as equipes de saúde.

Esse movimento foi sendo produzido e as equipes de gestão foram construindo seus desenhos para se aproximar 
das equipes. Como meio para isso foi utilizado o instrumento de autoavaliação e a elaboração da "Matriz de Intervenção" do PMAQ-AB que se somou ao uso dos instrumentos do Sistema de Gestão por Resultados da FESF-SUS, como o Plano de Ações e Resultados em Saúde (instrumento para planejamento semestral e pactuação de metas).

Nos momentos de encontro mensal e reuniões semanais da equipe de Apoiadores da FESF-SUS foram sendo produzidas metodologias e adaptados os instrumentos para o processamento das pautas das Políticas Nacional e Estadual da Atenção Básica. O grupo tinha uma grande capacidade de formulação neste aspecto, no entanto, o processamento e aplicabilidade dessa produção se chocavam com a realidade dos territórios.

Essa realidade revelava a necessidade de maior tempo e outras intervenções para acumulação de capacidade de governo e execução dos projetos por parte das gestões municipais. O movimento para a produção de coletivos de Gestão da Atenção Básica era muito incipiente e frágil. Ao mesmo tempo, tirar da zona de conforto os atores da gestão e trabalhadores, sempre era um processo tenso que necessitava mediação por parte do Apoiador. Essas temáticas foram emergindo no meu trabalho de Apoio, e o conflito entre a pauta institucional e as singularidades do território tornou-se um desafio para a gestão compartilhada, ainda mais em um cenário que apontava a necessidade de produção de resultados, e o período eleitoral que capturava a agenda dos gestores.

Uma das estratégias utilizadas para enfrentar o imobilismo desta situação foi justamente romper com o distanciamento entre gestão e equipes de saúde, produzindo micromovimentos para aproximar as equipes de gestão ao cotidiano das equipes de saúde. Como estratégia solicitava que alguém da equipe de gestão do município me acompanhasse nas visitas às Unidades de Saúde. Nessas visitas, além de estimular para que a gestão assumisse o papel de referência, para facilitar a elaboração da Matriz de Intervenção do PMAQ-AB e planejamento das equipes, era também para que a gestão pudesse apoiar 0 desenvolvimento das ações das equipes.

Um dos problemas observados foi a dificuldade de interlocução. Na maioria das vezes esse processo não foi tranquilo, envolvia conflito entre o que as equipes esperavam e o que a Coordenação da Atenção Básica e/ou Secretaria Municipal de Saúde sentiam-se autorizadas a produzir em termos de resposta às necessidades explicitadas. As reivindicações dos trabalhadores por melhores condições de trabalho direcionavam-se exatamente ao único ator que buscava se aproximar do seu cotidiano, e, curiosamente, geravam imobilismo e afastamento dos técnicos da gestão, que possuíam pouca governabilidade e baixa capacidade de agenciar recursos.

Acredito não ter produzido uma interlocução potente o suficiente entre esses dois atores para a conformação de algum grau de cogestão da Atenção Básica, pois foram poucas as experiências onde os arranjos produziram algo diferente da relação de um ator que demanda e outro que responde a ela. No entanto, acredito que esse movimento foi circunscrito por um tempo bastante desfavorável, pois representou apenas o início da aproximação entre os atores e a inclusão do conflito como dispositivo para uma cultura de negociação e pactuação. As relações de poder e saber não foram tratadas e, apesar de ter cumprido, nesse período, com a agenda institucional, garantindo com que as equipes e gestão desenvolvessem todas as etapas do PMAQ-AB com apoio do Sistema FESF-SUS, o processo foi interrompido pelas agendas eleitorais e pelo movimento de renovação contratual entre FESF-SUS e municípios. 
No fim do ano de 2012 a agenda de renovação contratual entre FESF-SUS e municípios é dificultada pela agenda eleitoral. Assim, o processo de renovação e negociação da dívida dos municípios parceiros da gestão do Sistema FESF-SUS é fragilizado. Com o aumento da inadimplência por parte dos municípios e redução dos contratos, logo aumenta a dependência financeira da fundação FESF-SUS pelo Estado e, paulatinamente, iniciase o processo de reforma administrativa. Neste cenário e com a mudança de objeto da Instituição, a proposta do Apoio Regionalizado com Apoiador descentralizado com o objetivo de atuar mais próximo das gestões municipais e das equipes de saúde para o desenvolvimento da carreira e dos serviços de forma compartilhada, passa a não ter justificativa, encerrando-se a experiência do Apoio descentralizado, no início de 2013.

\section{A experiência se inicia com sonhos: lugar comum para a projeção de desejos}

Este relato é um momento de explicitação de uma consciência da experiência que foi vivida. Na sua preparação foram resgatadas memórias que foram registradas pelos sentidos e por anotações de campo. É nesse momento que se constrói com mais clareza a leitura do território, à medida que se explicitam as experiências vividas nesse processo vêm à tona reflexões que estavam latentes, algumas não percebidas.

Assim são construídas as leituras do território e pistas de como movimentar-se nele, por isso a ação do Apoiador não deve ser capturada como um momento ou ato burocrático. Requer certo recolhimento para o retorno às memórias da experiência do campo e espaço protegido para colocar em análise a sua produção.

Vale ressaltar que em nossa rotina de trabalho entramos em contato com uma grande quantidade de experiências, vivências intensas que se dão na relação com o outro. Consequentemente, nossa demanda de trabalho precisa de um processo compensatório, para que as memórias sejam vivas, pois seguir a lógica de experiências sobrepostas só se sustenta diminuindo a intensidade da experiência ou mediante processos que as ressignifiquem cotidianamente; caso contrário, entramos no automatismo e padronização de nossas ações, por isso é fundamental apostarmos no papel da Educação Permanente e na Supervisão do Apoio .

Vale também observar que o tempo em que vivemos, dado à forma de produção é comum a mecanização de práticas, criando padrões para lidar com a nossa frequência de experiências. Outro fator é nossa dificuldade em lidarmos com as diversidades. O receio do novo e do diferente, nos leva a criar roteiros padronizados, protocolos e apresentações power point com slides infinitos que tentam prover respostas. Não quero dizer com isso que discordo da utilização desses instrumentos, chamo apenas a atenção para resumi-los enquanto ferramentas de trabalho, cuidando principalmente para que não anteceda o desejo, a necessidade sentida e demandada.

O desejo de viver esse cotidiano como lugar habitado me fazia perceber diferente a dinâmica das relações e modo de vida. O estranhamento já tinha outro lugar, pois sentir o sol do meio dia do interior me fazia vivenciar a necessidade de me recolher à sombra. As minhas experiências criavam conexões como imaginar a dificuldade de se realizar uma visita domiciliar ou se deslocar caminhando até a unidade de saúde. A dificuldade de me deslocar por meio do transporte 
coletivo me fazia literalmente rever o que carregava na minha "mochila" utilizada nas viagens de Apoio, e isso dialogava com o sentir a dificuldade de acesso a coisas e serviços de saúde, como também me fazia refletir sobre a necessidade do outro e do excesso de nossas ofertas.

A imagem da "mochila" cheia de peso cria uma metáfora para dialogar com o quanto de oferta é produzida em busca de respostas para o outro, e o papel de mediação do Apoiador sobre as necessidades que se apresentam e aquilo que se produz. Aponta para a condição de se fazer escolhas e identificar aquilo que é peso desnecessário (além do que, mala de rodinha não anda em rua de pedra e estrada de terra). A experiência "piloto" do Apoio descentralizado da FESF-SUS me oportunizou habitar, como estrangeiro, um território e junto a isso observar, escutar e sentir estando mais próximo do cotidiano que se expressa nas relações e no modo de vida. Aponta para a necessidade de equilibrar a reprodução dos coletivos e das organizações diante do valor de uso daquilo que é produzido, principalmente para o cotidiano dos trabalhadores da saúde e população usuária do sistema público de saúde.

A proposta do Apoio descentralizado oportunizou evidenciar essas necessidades e vivenciar o lugar de mediação entre oferta e demanda, a utilização dos instrumentos da Gestão por Resultados do Sistema FESFSUS e do desenvolvimento do PMAQ-AB ajudaram no processamento da demanda das equipes de saúde e das gestões. $O$ arranjo oportunizou potencializar a relação e a mediação de pactuação de metas e ações fortalecendo a perspectiva da gestão compartilhada. No entanto, não acredito que isso seja uma condição apenas de desenhos descentralizados ou impossível de ser produzido a partir do nível central; a diferença da experiência foi estar na condição de estrangeiro ao tentar compreender e habitar este território existencial.
Na vida cotidiana me senti convocado a realizar coisas básicas como separar e reciclar o lixo, por uma postura éticopolítica e por sentir o impacto que a forma de destinação do lixo exerce sobre a vida das comunidades e municípios da região. A maioria das equipes de saúde, com as quais estive mais próximo, apontava pelos instrumentos de diagnóstico comunitário e planejamento das ações, o lixo e as condições sanitárias como problemas da comunidade. E a escolha por habitar este território me colocava na condição de sentir-me parte dos problemas dessa vida em comunidade. Passos, Kastrup e Escóssia (2010) consideram na pesquisa cartográfica, que habitar o território envolve nível de convivência, a explicitação clara da posição que se assume nesse território e as relações que se estabelece com as pessoas.

Neste aspecto, a memória de conversas, gestos, olhares, movimentos e experimentação vivenciada nesse lugar de trabalho, e onde a vida acontece, resgatados neste texto, não se resumem à ilustração de mapas para o trânsito no território; representou um processo cartográfico, e, habitá-lo como estrangeiro, possibilitou conhecê-lo mais e me afetar com seus movimentos.

\section{Referências}

BERTUSSI, D. C. O apoio matricial rizomático e a produção de coletivos na gestão municipal em saúde. Rio de Janeiro: UFRJ. Faculdade de Medicina, 2010.

BRASIL. Ministério da Saúde. Secretaria de Atenção à Saúde. Departamento de Atenção Básica. Programa Nacional de Melhoria do Acesso e da Qualidade da Atenção Básica 
(PMAQ): manual instrutivo. Brasília : 2011. Disponível em: <http://www.saude.mt.gov.br /upload/documento/165/ pmaq-manual-instrutivo-\%5B165-040412-SES-MT\%5D. pdf>. Acesso em: 20 fev 2013.

CAMPOS, G.W. S. Saúde Paidéia. 2. ed. São Paulo: Editora Hucitec, 2003. 185 p.

CAMPOS, G. W. S.; GUERREIRO, A. V. P. Manual de Práticas de Atenção Básica: saúde ampliada e compartilhada. 1.ed. São Paulo: Aderaldo \& Rothschild, 2008.

GONÇALVES, R.B.M. Tecnologia e Organização Social das Práticas de Saúde. São Paulo: Hucitec, Rio de Janeiro: Abrasco, 1994.

MARX K. O Capital. 14. ed. São Paulo: Bertrand Brasil, 1994. v.1.

\section{Inserção e Acolhimento de trabalhadores numa equipe de Apoio Institucional da Diretoria de Atenção Básica ${ }^{1}$}

Sílvia Cardoso, Françoise Oliveira , Alan Costa, Rosana Fialho, Daisy Matos.

MERHY, E.E. A cartografia do trabalho vivo. 3.ed. São Paulo: Editora Hucitec; 2002.

PASSOS, E.; KASTRUP, V.; ESCÓSSIA, L. (Org.) Pistas do método da cartografia: Pesquisa-intervenção e produção de subjetividade. Porto Alegre: Sulina, 2010. 207 p.

A equipe da qual fazemos partecompõea Coordenação de Apoio e Desenvolvimento do Apoio Institucional da Diretoria da Atenção Básica da Secretaria da Saúde do Estado da Bahia (COAD/DAB/SESAB).

O Estado da Bahia, de acordo com o Plano Diretor de Regionalização $\neg$ PDR $\neg$ (BAHIA, 2007), é dividido em nove Macrorregiões de Saúde. De modo que somos referência para a Macrorregião Centro-Leste, de forma que apoiamos setenta e três municípios do Estado no desenvolvimento e implementação de políticas relacionadas à Atenção Básica, tanto de âmbito nacional como estadual.

O território de nossa atuação é composto por cinco Diretorias Regionais de Saúde (DIRES) e quatro Regiões de Saúde, a saber: Feira de Santana, Serrinha, Itaberaba e Seabra, apresentando características político-econômicas,

${ }^{1}$ A Diretoria de Atenção Básica compõe o organograma estrutural e funcional da Superintendência de Atenção Integral à Saúde (SAIS) da Secretaria da Saúde do Estado da Bahia. 
socioculturais e condições de saúde bem diversificadas, o que acaba sendo um desafio para o desenvolvimento de nossa prática e organização do processo de trabalho de nossa equipe de Apoio.

No mapa a seguir, destacamos a localização da Macrorregião Centro-Leste.

Mapa 1 Localização da Macrorregião Centro-Leste no Estado da Bahia.

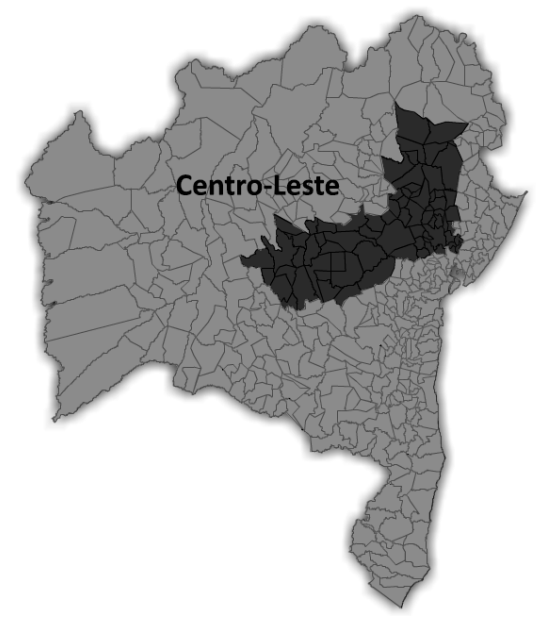

(Fonte: arquivo pessoal) => precisamos da imagem (JPG, PNG)

A equipe Centro-Leste ${ }^{2}$ atualmente é constituída por cinco profissionais de formações e vínculos diversos: uma enfermeira sanitarista, pertencente ao quadro efetivo da SESAB; uma farmacêutica sanitarista, duas odontólogas sanitaristas e um professor de educação física; estes três últimos pertencentes ao quadro de pessoal efetivo da Fundação Estatal Saúde da Família (FESF-SUS) ${ }^{3}$. Todos com

2 Vale ressaltar que desde 2007, esta equipe sofreu modificações na sua composição, com entradas e saídas de profissionais que contribuíram muito para a qualificação do apoio os municípios e DIRES da macrorregião.

3 Em março do ano de 2012, foi assinado o Contrato de Programa entre a Secretaria de Saúde do Estado da Bahia (SESAB) e a Fundação qualificação e atuação seja na assistência, seja na Gestão Municipal, contudo apenas um de nós tinha experiência prévia com o trabalho de Apoio Institucional. Era uma novidade para a maioria e um desafio.

Com estas considerações faremos um relato e um breve resgate de nossas inserções enquanto trabalhadores da equipe de Apoio Institucional registrando um pouco de nossos sentimentos, percepções, compreensões, expectativas e reflexões acerca do processo de recepção e inserção de cada um de nós neste modelo de gestão porque compreendemos que este momento de formação inicial (acolhimento dos trabalhadores) é de fundamental importância para a integração e implicação deste sujeito ao projeto institucional de uma gestão estadual de saúde na Atenção Básica.

O processo de recepção inserção de cada um dos autores ocorreu em momentos bem distintos na trajetória da DAB no período de 2007 a 2013. Portanto, o objetivo de nosso relato é apresentar como vivenciamos o processo de acolhimento na DAB e na equipe de Apoio Institucional da Macrorregião Centro-Leste, nesse período.

Ao assumirmos abordar o tema a partir da nossa percepção e de nossos sentimentos, admitimos a possibilidade de esse relato não conseguir mensurar, de forma precisa, o impacto dessa vivência profissional, tanto para nós como para a Instituição. No entanto, consideramos que a construção deste texto nos oportunizou vivenciar um momento potente de imersão e aprofundamento acerca do papel do acolhimento de trabalhadores, como estratégia de formação inicial (recepção e inserção) no processo de

Estatal Saúde da Família (FES-SUS) com o objetivo de desenvolver o Projeto Apoio Institucional para implementação do Programa Nacional de Melhoria do Acesso e da Qualidade da Atenção Básica (PMAQ-AB) por meio deste contrato estava prevista a lotação de 15 trabalhadores concursados da FESF-SUS para trabalharem como assistentes de apoio institucional na DAB. 
trabalho em equipe no Apoio Institucional.

O foco deste acolhimento é preparar o trabalhador para atuar como Apoiador Institucional no contexto da DAB/ SESAB. Sendo assim, prepara-se o trabalhador para atuar junto com a Gestão Municipal: elaborando a cartografia para auxiliar numa análise de contexto; identificando potencialidades e fragilidades locais; construindo "Planos de Ação" que contemplem estratégias e construam soluções pactuadas com os gestores municipais, no intuito de implementar a política de Atenção Básica; respondendo e acompanhando os processos estruturados como credenciamento de serviços, adesão a programas, demandas da Auditoria e Ouvidoria SUS/BAHIA e da Controladoria Geral da União (CGU).

O resgate dessa história tem início a partir das experiências do trabalhador que atua há mais tempo, e daquele que se inseriu de forma mais recente em nossa equipe. Convidamos você, caro leitor, a mergulhar conosco nesta vivência.

\section{Das inserções no Apoio Institucional}

\section{Fazer e aprender}

Sou enfermeira, sanitarista, do quadro efetivo da SESAB, lotada na DAB no ano de 2007, sendo recebida pela coordenação do setor, que me apresentou os projetos políticos até então construídos e os materiais para estudo, conduzindo-me imediatamente à equipe de referência da Macrorregião Centro-Leste, que no momento contava com apenas uma trabalhadora.

Não me senti acolhida ao ser inserida na equipe.
Não tinha clareza de minha função naquele espaço e tive que compreendê-la sozinha e isso me deu a sensação de um trabalho individualizado. Sentia que minha experiência anterior na Gestão Municipal agregava mais qualidade na minha prática como Apoiadora na Gestão Estadual, porém a minha insegurança era frequente no encontro com gestores, conselheiros e trabalhadores municipais. A minha percepção, naquele momento, é que eu desempenhava uma função mais operacional em relação aos demais Apoiadores contratados por meio de consultoria ${ }^{4}$, que ocupavam o mesmo espaço de trabalho. Assim como eu, os colegas contratados foram inseridos nas equipes de Apoio Institucional organizadas seguindo o PDR na área da saúde.

Como parte destes Apoiadores contratados vinha de outras localidades do país, para mim, as propostas políticas elaboradas por estes trabalhadores, não dialogavam com a cultura, extensão territorial e peculiaridades locorregionais do Estado da Bahia.

Com isto, os conflitos aumentaram no interior das equipes e na construção de consensos coletivos, pois passou a existir competitividade entre os próprios trabalhadores. Eu sentia que não compartilhávamos projetos e nem construíamos juntos na equipe. Os nossos desentendimentos não eram resolvidos em reuniões de trabalho, que se concentravam apenas em discussões acerca de planejamento técnico e repasses de informações.

Naquele ano, a Diretoria $\neg \mathrm{DAB}$ tinha necessidade de organização do processo de trabalho e qualificação de forma a se aproximar dos municípios e Diretorias Regionais de Saúde. E, foi nesta conjuntura que o Apoio Institucional, baseado no Método Paidéia (CAMPOS, 2003), foi proposto ${ }^{4}$ Desde 2007, com o objetivo de ampliar a equipe de trabalhadores, alguns dos Apoiadores Institucionais da DAB passaram por contratos de consultoria com vínculos como por exemplo: Projeto Saúde Bahia e Projeto de Expansão e Consolidação Saúde da Família (PROESF). 
pela equipe dirigente da DAB. A partir daí, surgiu a busca pelo entendimento coletivo e uma nova perspectiva de atuação na gestão estadual em que todos os trabalhadores criavam, construíam, refletiam, executavam e avaliavam as ações, expressando suas ideias e vivências.

No ano de 2008, a Diretoria $\neg$ DAB vivenciava uma produção em ritmo frenético, e eu sentia que era necessário intensificar os estudos para acompanhar todos os projetos estratégicos para a Atenção Básica, e, realizar o Apoio Institucional aos municípios. A Instituição contratou um analista institucional para iniciar as rodas de discussão e de reflexão, com a finalidade de amadurecer como organizar e estruturar a DAB, na lógica do Apoio Institucional. Os principais temas abordados foram: o significado do Apoio Institucional; a equipe e o trabalho coletivo; os limites da Atenção Básica e a busca do apoio integrado na SESAB.

Na medida em que o trabalho no Apoio se desenvolvia, a formação dos trabalhadores foi se consolidando durante os dois primeiros anos da gestão trazendo amadurecimento para todos, inclusive para mim. Contudo, a formação inicial de trabalhadores ainda se configurava como um grande desafio.

\section{Um grande desafio}

Posso dizer que esta tem sido uma grande experiência para minha vida profissional. Sou farmacêutica e minha atuação como sanitarista iniciou-se com a Residência Multiprofissional em Medicina Social, com ênfase em Saúde da Família, desenvolvida pelo Instituto de Saúde Coletiva da Universidade Federal da Bahia (ISC/UFBA), realizada entre os anos de 2002 a 2004, portanto, minha inserção na DAB não foi algo tão novo para mim, talvez pelo fato de já ter vivenciado e atuado com o objeto da Atenção Básica em municípios do Estado e na própria SESAB.
A atuação na residência contemplou três momentos prioritários sequenciais: iniciou-se com minha atuação numa equipe de Saúde da Família; em seguida, na Coordenação Municipal de Atenção Básica; por fim, na Gestão Estadual da Atenção Básica. As três experiências foram muito ricas, pois pude vivenciar cotidianamente tanto a operacionalização das diretrizes da Estratégia de Saúde da Família no contato direto com a equipe de Saúde da Família (vínculo, territorialização, cartografia, planejamento das ações e análise das demandas para construção de agendas de equipe), como o processo de trabalho das gestões municipal e estadual, que tinha o intuito de ampliar, acompanhar, fortalecer e qualificar as ações da Atenção Básica junto com as equipes de Saúde da Família.

Comecei minhas atividades na DAB em abril de 2008. Não demorei muito para ser inserida numa equipe, tendo em vista a necessidade da diretoria. Assim, fui integrada à equipe Centro-Leste. Ao ingressar no Apoio Institucional, minha expectativa era acompanhar mais de perto e com mais periodicidade os municípios por meio de visitas aos territórios. No decorrer do tempo, percebi que estas visitas estavam intrinsecamente ligadas à prática do Apoio Institucional.

Não recebi um acolhimento estruturado, apenas participei de uma curta apresentação feita por alguns trabalhadores da diretoria sobre os projetos estratégicos prioritários naquele ano, mas não foi suficiente.

O fato de não ter havido um acolhimento, me deixou com muitas dúvidas por isso me senti insegura. A Diretoria $\neg$ DAB vivenciava um momento cuja produção era intensa num ritmo frenético para a qualificação de projetos da Atenção Básica e, não tinha como não me sentir perdida e confusa naquele espaço, onde eram discutidas muitas questões e temas que eram novos para mim. Além disso, 
a forma de organização do trabalho era distinta do tipo de gestão tradicional e verticalizada a qual eu estava mais acostumada. Meus colegas até tentaram fazer algo semelhante a um "acolhimento", mas eu percebia que, por muitas vezes, eles se sentiam tão perdidos quanto eu.

Chegamos a vivenciar na equipe alguns conflitos internos por falta de compreensão e diálogo que, de alguma maneira, dificultava o desenvolvimento do nosso processo de trabalho. Eram tantas demandas, inúmeras reuniões e uma "enxurrada" de e-mails para responder. O tempo transcorria e eu me angustiava porque não sabia até que ponto minha forma de operar e atuar como trabalhadora da Gestão Estadual coadunava com a lógica do Apoio Institucional.

Posso dizerque fuime tornando Apoiadora no processo e algo que colaborou bastante para o aprimoramento, entendimento e qualificação do meu trabalho "em ato" foram as agendas externas nos territórios, as reuniões de Educação Permanente, os momentos de análise institucional vivenciadas por todos os trabalhadores da Diretoria e a possibilidade de colaborar na construção de um material, intitulado como Manual do Apoiador Institucional ${ }^{5}$, que tinha como principal objetivo apresentar o funcionamento da DAB, favorecendo a inserção e acolhimento dos novos trabalhadores, para uma maior compreensão da lógica do Apoio Institucional e conhecimento dos fluxos, normas e atividades.

No decorrer do tempo, fui percebendo que a melhoria do meu processo de trabalho e o de toda a equipe Centro-Leste estava diretamente ligada: à forma como nos relacionávamos; a nossa capacidade de escuta cuidadosa e direcionadora a partir de nossas reuniões de

5 O Manual do Apoiador foi um documento desenvolvido pela Coordenação da COAD no ano de 2011 que continha as atribuições do Apoiador Institucional e os principais fluxos de trabalho. equipe; ao aprofundamento de leituras e trocas acerca das vivências no território; a nossa capacidade de se permitir experimentar o funcionamento de uma gestão colegiada, dentro de uma Instituição que atua predominantemente com gestão tradicional.

Vivenciei minhas primeiras agendas externas juntamente com colegas de equipe e esta parceria foi crucial para perceber e viver: a construção coletiva entre os parceiros (Apoiadores, gestores e trabalhadores); a importância da abertura para escuta, reflexão e elaboração de planos de ações factíveis, flexíveis e pactuados para o enfrentamento dos problemas no decorrer dos prazos estabelecidos conjuntamente. Ao longo do tempo, fui me sentindo mais segura, aprimorei minha prática e busquei me qualificar para lidar com as diversas demandas que surgiam a cada ida ao território.

Para mim, isso era um grande desafio! $E$, confesso que continua sendo porque apesar de todos os avanços e conquistas, tanto no âmbito profissional como no pessoal, percebo que ainda precisamos avançar muito. Quando visito os territórios municipais percebo um distanciamento imenso entre os trabalhadores das equipes de Atenção Básica e os profissionais que atuam na Gestão Municipal; fica evidente o quanto a grande maioria das equipes de gestão atua de forma autoritária e centralizadora, com visão voltada exclusivamente para lógica da supervisão, com pouca percepção sobre a importância de estruturar momentos de reuniões periódicas para viabilizar a escuta e trocas sobre o cotidiano do trabalho.

Trabalhar na DAB tem sido uma "riqueza" para mim porque tem me proporcionado um aprendizado ímpar, com todas as dores e as delícias que qualquer experiência tem. Ao vivenciar todo esse desafio, pude ingressar paulatinamente no universo do Apoio Institucional. 


\section{Ingressando no mundo do Apoio Institucional}

Sou professor de educação física e atuo na DAB desde junho de 2012, como Apoiador Institucional. Antes do trabalho nesta modalidade de apoio, atuei por um ano e meio com Apoio Matricial (CAMPOS, 2007a), entre os anos de 2010 e 2011, integrando uma equipe do Núcleo de Apoio a Saúde da Família (NASF) responsável pela retaguarda de nove equipes de Saúde da Família num município baiano.

Em meio às atividades de troca de saberes, práticas e competências desenvolvidas nesta experiência numa equipe de NASF, desenvolvi diversas atribuições que ultrapassavam os limites do matriciamento. Dentre estas atividades, destaco: desenvolvimento de espaços de Educação Permanente para os profissionais; articulação com outras secretarias do governo e outras instituições municipais da saúde; apoio à gestão na organização de conferências de saúde; mediação de conflitos; desenvolvimento e implantação de diversos projetos de intervenção buscando a mudança do modelo de atenção das equipes de Saúde da Família; organização de eventos temáticos.

Neste sentido, minha expectativa ao ingressar no Apoio Institucional na DAB era de desempenhar um apoio mais próximo dos municípios e direcionado à estruturação das equipes de Saúde da Família no que tange à mudança do processo de trabalho. Esperava contribuir mais diretamente com reflexões e atividades de Educação Permanente, que possibilitassem a incorporação de novas ferramentas de cuidado nas equipes de Saúde da Família.

Recordo que meu primeiro contato com a Diretoria foi durante a visita para realização de uma entrevista com a Coordenação da COAD, visando ao meu ingresso na mesma. Aquele clima de seleção de candidatos e o primeiro olhar para o ambiente físico amplo, com muitas mesas, cadeiras e a presença de vários trabalhadores organizados em "ilhas" , sem divisão em salas, tudo aquilo fazia-me refletir "este lugar é interessante!"

Durante a entrevista, fui surpreendido com elementos de análise que compreendiam aspectos da política de saúde, com ênfase na humanização do cuidado. Os questionamentos buscavam analisar meu conhecimento prévio quanto ao cuidado em saúde, identificando também minhas potencialidades para oportunizar o desenvolvimento do meu processo de trabalho na equipe. Toda a condução pela equipe da coordenação se deu de forma dialógica e horizontalizada, com ausência de expressões hierárquicas tão comuns neste tipo de atividade. Saí deste momento muito instigado para entender melhor essa nova dinâmica de trabalho, buscando me debruçar sobre textos que abordavam Apoio Institucional na Gestão Estadual. Naquele momento, minha busca não foi bem sucedida porque encontrei poucas respostas.

Enfim, fui contratado e ingressava junto com mais quatro novos colegas no mundo do Apoio Institucional. Havia, no mesmo grupo, trabalhadores com experiência em Coordenação Municipal de Saúde Bucal e de Atenção Básica; Apoiadores matriciais; enfermeiras e odontólogas de Saúde da Família. Como qualquer recém-chegado a novas terras, carregava comigo alguns questionamentos: 0 que exatamente faz um Apoiador Institucional? Como serei recebido? Como o grupo de Apoiadores e a coordenação estabelecerão as relações de poder com áreas de pouca expressão na gestão como a educação física? As respostas começaram a ser dadas com novas surpresas.

No primeiro dia de trabalho na Diretoria, minha expectativa era ser inserido imediatamente numa equipe

${ }^{6} \mathrm{Na}$ COAD, denominamos de ilha o espaço físico ocupado por cada equipe de Apoio Institucional. 
de Apoio e ser apresentado às atividades operacionais da mesma. Ao invés disso, fui informado pela coordenadora que iria passar por um momento de acolhimento de forma que eu pudesse me aproximar da dinâmica de trabalho compreendendo melhor as políticas para Atenção Básica e a lógica de Apoio Institucional.

Esta vivência foi muito importante para mim porque foi-me apresentado o funcionamento geral da DAB, ou seja, as principais atividades desenvolvidas e as diretrizes do Apoio Institucional. Durante o acolhimento, fui avaliado individualmente quanto as minhas qualidades e dificuldades para inserção nessa nova função. Além disso, fui direcionado a fazer as primeiras leituras de textos que abordavam: o fazer Apoio Institucional; as políticas e projetos vigentes na Atenção Básica naquele momento.

Em todo esse processo de recepção e inserção na DAB tive a possibilidade de trocar impressões com outros colegas. Aproveitando a oportunidade para: analisar criticamente as políticas de saúde; tirar dúvidas uns com os outros quanto ao entendimento do trabalho do Apoio; trocar experiências a partir da vivência particular de cada um nos diversos espaços de saúde que passamos antes de adentrar a Diretoria.

Quinze dias depois fui apresentado à equipe de Apoio Institucional da Macrorregião Centro-Leste composta por mais duas colegas. Novamente, minha principal ansiedade era como seria incluído nesta equipe. Fui recebido de forma bastante cortês pelas colegas. O interessante é que não fui colocado na condição de mero espectador da tarefa nem como alguém que tivesse que "se virar" sozinho. Desenvolvia minhas tarefas individuais com o apoio necessário a ser dispensado para qualquer recém-chegado.

Dois meses após ingressar no trabalho da equipe Centro-Leste tive meu primeiro contato com o território ao participar de uma reunião com os Apoiadores das DIRES, para apresentação e discussão da proposta metodológica de uma oficina voltada para trabalhadores e gestores municipais de Atenção Básica. Logo em seguida, aconteceu meu primeiro contato com os Coordenadores da Atenção Básica em uma oficina sobre saúde materno-infantil. Nestes dois momentos fui devidamente apresentado ao grupo, assumindo funções de mediação e facilitação de grupo, mas ainda sem grande protagonismo, sendo respeitado e respeitando o tempo natural de conhecimento entre os atores.

Durante estes primeiros encontros com a realidade do Apoio, percebi a importância daquela primeira semana de acolhimento na DAB porque tinha me proporcionado maior conhecimento, maior segurança para desempenho das tarefas e para o contato inicial com os colegas de trabalho da Diretoria e com os gestores municipais, despertando em mim sensação de pertencer a este coletivo.

\section{Sensação de pertencer}

Minha caminhada como Apoiadora Institucional da DAB iniciou-se em agosto do ano de 2012. Sou cirurgiãdentista e fui recebida pelos coordenadores da COAD, que iniciaram o meu processo de acolhimento com mais três trabalhadoras, realizando: rodas de conversa; diálogos sobre as nossas percepções e expectativas; socialização das nossas experiências em saúde; apresentações dialogadas sobre a prática da Diretoria e dos trabalhadores da DAB. Aos poucos, fui entrando em contato com os inúmeros conteúdos que fazem parte do universo da Atenção Básica, bem como fui participando dos espaços coletivos de construção e formação dos sujeitos.

O meu acolhimento foi processual e demorou cerca 
de um mês até a minha integração na equipe. Durante este período, fui me aproximando das políticas que permeiam a Atenção Básica e do novo modelo de se pensar e realizar a gestão colegiada. A princípio fiquei sem entender como romperia com minha lógica objetiva e verticalizada com foco em supervisão, a qual estava acostumada. A insegurança emergiu por achar que não conseguiria em um curto espaço de tempo me apropriar das inúmeras leis, portarias, projetos, normas técnicas e diversidade de territórios. Ao mesmo tempo, esse desafio me mobilizou a uma inteira entrega à experiência de atuar num espaço que permitia uma contínua interação e aprendizado. Tudo era muito novo para mim, pois anteriormente atuei como Coordenadora Municipal do serviço de controle da tuberculose, com uma prática focada em ações estruturadas.

A minha atividade anterior numa Coordenação Municipal de um programa voltado para a Vigilância em Saúde, mas executado no espaço da Atenção Básica, possibilitava que eu desenvolvesse as minhas atribuições com total autonomia. Apesar de contar com mais duas profissionais na condução desta coordenação, o papel de planejar, representar e definir as estratégias a serem desenvolvidas ficavam centradas em mim, não havia produção coletiva. Eu assumia a responsabilidade e representatividade pelo referido programa em várias instâncias e espaços de deliberação, desde o Ministério da Saúde até os Conselhos Locais de Saúde e as equipes de Saúde da Família.

$O$ cuidado com que fui recebida desde o primeiro dia na DAB possibilitou a criação de vínculos e a sensação de pertencer a um lugar diferenciado de trabalho, e isso foi fundamental para iniciar minha caminhada nessa nova função.

Ao ser inserida na equipe da Macrorregião Centro-
Leste, me senti acolhida ao ouvir uma frase que me marcou: "Não se esqueça que você nunca estará só. Se acertarmos ou errarmos será sempre de forma coletiva". Isso me trouxe uma sensação de leveza por saber que as responsabilidades seriam compartilhadas. Iniciei as minhas atividades no território contando com o apoio da equipe e, dessa forma, processualmente fui me sentindo mais segura.

Apesar do cuidado recebido, a minha prática anterior ainda me marcava muito e isso gerou alguns conflitos, pois tinha dificuldade de produzir em equipe, buscando na maioria das vezes resolvermos individualmente as demandas que surgiam. Aos poucos fui entendendo o significado da função Apoio, a partir do feedback dos colegas; das reuniões de equipe; das vivências no território; dos Apoiadores das DIRES, passando a valorizar e estimular o protagonismo e o olhar crítico-reflexivo dos sujeitos envolvidos no planejamento, execução e acompanhamento das políticas de saúde.

Hoje, passados quase um ano e meio, percebo quanto o acolhimento realizado pela Diretoria e pela equipe Centro-Leste foi fundamental no aprendizado, e na minha atuação mais qualificada, como Apoiadora no território, estando mais aberta e sensível à escuta das necessidades trazidas pelas DIRES, trabalhadores da assistência, gestores de vários níveis e integrantes da minha equipe. Para mim, poder vivenciar um espaço coletivo de prática reflexiva é uma oportunidade singular de crescimento pessoal e profissional. O sentimento de pertencer a esse grupo evidenciou a possibilidade e factibilidade da construção coletiva baseada na formação contínua dos sujeitos nos espaços institucionais. 


\section{Construção coletiva}

Sou cirurgiã-dentista e sanitarista pela Universidade Federal da Bahia-UFBA e tive a oportunidade de vivenciar o Apoio Institucional dentro da proposta de Gastão Wagner (CAMPOS, 2007b) na FESF-SUS e, para mim, foi uma experiência única. O Método Paidéia (CAMPOS, 2007b) era tão distante, algo tão impalpável, restrito aos livros e as leituras da Residência Multiprofissional em Saúde Coletiva pelo ISC/UFBA, que jamais imaginei que poderia experimentar esta metodologia de trabalho.

Quando adentrei na sede da FESF-SUS, fiquei impactada com a maneira de operar a gestão, com a escuta do trabalhador, a autonomia dos sujeitos, a construção coletiva, o estímulo ao estudo e a Educação Permanente para os profissionais. Para mim, o processo dinâmico de construção trouxe muitos aprendizados, mas também muitos desafios. A cada dia, sentia necessidade de ler cada vez mais. Muitas vezes, me senti ansiosa com o processo agitado do trabalho, mas com o passar do tempo fui aprendendo a lidar com minhas emoções e o que foi permanecendo em mim foram os ganhos profissionais.

Quando fui lotada na DAB em julho do ano de 2013, já no primeiro dia soube que seria integrada à equipe da Macrorregião Centro-Leste. A Coordenadora da COAD foi me aproximando da rotina do trabalho na Diretoria, ofertandome vários textos, para que eu pudesse me debruçar sobre eles para a devida leitura. Daí que li a Política Estadual da Atenção Básica (BAHIA, 2013), o Manual do Apoiador Institucional, o artigo "A percepção dos trabalhadores sobre a construção de uma gestão participativa na Diretoria da Atenção Básica da Secretaria da Saúde da Bahia" (CUNHA; NASCIMENTO, 2009), elaborado pelos Apoiadores Institucionais Maria Aguinê Evangelista Cunha e Marco Antônio Minervino do Nascimento, e pude explorar a estrutura e o funcionamento do meu ambiente de trabalho.

O sentimento foi de acolhimento porque a Coordenadora tinha ciência de que estava afastada de minhas atividades laborais há quase dois anos e me ofereceu oportunidade de aprofundar e atualizar meu conhecimento acerca de vários materiais sobre fluxos institucionais e políticas de saúde que embasariam minha atuação como Apoiadora Institucional. Foram trinta dias de mergulho em leis, portarias, notas técnicas e muitos outros documentos e artigos que me auxiliaram no aprendizado do trabalho.

Quando estava prestes a ser inserida na equipe, uma colega me recebeu com muito carinho, foi extremamente acolhedora e me auxiliou na compreensão de vários processos na equipe como Auditoria e Ouvidoria SUS/ $\mathrm{BA}$, análises de credenciamento de serviços, ofícios, ou seja, toda a intensa rotina do Apoiador. Minha equipe foi acolhedora e muito receptiva na minha chegada. Tiveram paciência para me ensinar todas as demandas do trabalho, para perceber o compasso do outro na busca da construção coletiva.

A primeira viagem para o território provocou em mim um sentimento de insegurança em representar a Diretoria nas agendas externas, mas fui enfrentando os momentos com apoio de uma colega e a cada dia, fui me sentindo mais confiante para discutir a qualificação da Atenção Básica com as DIRES e as gestões municipais.

Entretanto, sentia-me muito à vontade com as equipes de Saúde da Família para emitir opiniões, sugestões e experiências vividas que auxiliavam a outros colegas na Estratégia de Saúde da Família.

Com o passar dos meses, estou cada vez mais apta para desempenhar minha função com protagonismo e autonomia, mas quero registrar o quanto seria difícil ter 
que construir esta vivência sozinha e sem o apoio e o acolhimento dos meus colegas.

\section{Resgatando a lógica do Apoio Institucional na DAB}

Desde o ano de 2007, o Apoio Institucional foi escolhido como um dos eixos estruturantes da $\mathrm{PEAB}^{7}$ com o intuito de repensar e redirecionar o modo de operar gestão e de desenvolver processos de trabalho em espaços coletivos, buscando uma relação mais democrática e participativa entre Estado e municípios. A lógica do Apoio Institucional passa a fazer parte do processo de trabalho das equipes de Apoio da DAB e dos técnicos de referência da Atenção Básica das Diretorias Regionais de Saúde.

Naquele momento, buscava-se um novo modo de ação que reorientasse a organização e o modelo de gestão no âmbito estadual com vistas a: estabelecimento de diálogo; a realização de pactuação; a oferta de Apoio para o enfrentamento concreto dos desafios vividos pelos municípios no desenvolvimento da Atenção Básica.

A lógica do Apoio Institucional tem como finalidade fomentar práticas de cuidado usuário-centradas, construindo espaços de cogestão (CAMPOS, 2007b), fortalecidos por rodas de Educação Permanente que aconteciam periodicamente envolvendo os trabalhadores da DAB e atores da região. Neste contexto, pretende-se a ampliação da capacidade da autonomia e protagonismo dos sujeitos envolvidos a partir da compreensão do seu próprio processo de trabalho, na qual os objetivos institucionais deveriam ser articulados aos saberes e interesses dos trabalhadores. Nos espaços coletivos vivenciados, criamos momentos de análise, onde tomamos por base a reflexão

${ }^{7}$ Em 2013, os eixos estruturantes da Política Estadual foram ampliados, fortalecendo o Apoio Institucional como um dos seis eixos da nova política. das dificuldades e também os resultados alcançados pelas nove equipes de Apoio Institucional da DAB, facilitando a tomada de decisão, ampliando, dessa maneira, a implicação dos atores envolvidos.

O Método Paidéia (CAMPOS, 2003), adotado pela DAB em 2007, é uma postura que busca reformular os tradicionais mecanismos de gestão e parte do pressuposto de que as funções de gestão se exercem entre sujeitos, ainda que com distintos graus de saber e de poder, assumindo que todo trabalho tem uma tripla finalidade e produz efeitos em três sentidos distintos. Primeiro: objetiva e interfere com a produção de bens ou serviços para pessoas externas à organização $\neg$ se trabalha para um outro em referência às equipes de operadores; segundo: procura sempre assegurar a reprodução ampliada da própria organização; terceiro: termina interferindo na produção social e subjetiva dos próprios trabalhadores e dos usuários.

\section{O papel do acolhimento na formação inicial do Apoiador Institucional}

Entendendo que a "função" Apoio é uma inovação no campo da gestão estadual de saúde e necessita de processos formativos contínuos, a DAB vem promovendo momentos de acolhimento para os novos trabalhadores que ingressam na sua equipe. Em 2007, os trabalhadores eram inseridos nas equipes de Apoio Institucional sem entendimento adequado e aprofundado do papel que iriam exercer no território, numa dinâmica intensa de produção de políticas e frentes de ação. Até então, o acolhimento aos trabalhadores não era compreendido como uma ferramenta necessária para o desenvolvimento e qualificação do processo de trabalho das equipes de Apoio.

A partir de 2011, com a elaboração do Manual 
do Apoiador Institucional, o acolhimento dos novos trabalhadores pela coordenação da COAD passou a se tornar uma ferramenta dinâmica de formação e integração. A partir de então, o acolhimento contempla momentos de apresentação do trabalhador abordando suas experiências, expectativas e conhecimentos prévios na saúde, especificamente no âmbito da Atenção Básica e Gestão. Disponibiliza-se material de suporte para leitura e estudo, e paralelo a isso, o trabalhador é convidado a participar de todos os espaços coletivos da diretoria, independente de sua inserção na equipe, interagindo com os demais colegas, com o ambiente de trabalho, com a dinâmica das equipes de Apoio Institucional.

Acreditamos que neste período de aproximação com o trabalho, a coordenação tem a oportunidade de conhecer melhor o perfil destes novos trabalhadores, suas fragilidades, potencialidades, planejando a recomposição das equipes de forma que as aptidões desses trabalhadores possam agregar ainda mais qualidade ao trabalho coletivo.

Para que um novo trabalhador fosse selecionado para uma determinada equipe, a Coordenadora identificava previamente as vagas existentes, procurava saber do trabalhador qual o sentimento em relação a cada equipe que se encontrava com vagas a serem preenchidas, e após avaliação do contexto desse trabalhador, promovia uma "roda de conversa" com os integrantes da equipe escolhida para que todos pudessem validar essa possibilidade. Após consenso coletivo, era comunicado ao novo trabalhador a equipe de Apoio Institucional na qual iria ingressar e, a partir daí, o processo de acolhimento teria continuidade com os colegas, partilhando atividades e projetos a serem desenvolvidos, materiais diversos, aprendizados, facilidades e dificuldades do processo de trabalho.

O acolhimento realizado pela equipe possibilita ao novo trabalhador a aproximação com o cotidiano do trabalho. Assim, o novo Apoiador passa a ter acesso aos demais conhecimentos sobre os processos administrativos, sobre funcionamento interno da equipe e sobre a cartografia dos municípios que compõem as Macrorregiões, contando com o apoio dos colegas e das Diretorias Regionais de Saúde.

A inserção do Apoiador no território para o desenvolvimento das atividades de Apoio junto com as Regionais de Saúde e municípios, ocorre de forma que o recém-chegado seja auxiliado por um colega com maior vivência na equipe. Deste modo, o novo Apoiador coloca em prática todos os conhecimentos adquiridos articulados ao contexto prático e vai se tornando mais seguro para desenvolver o Apoio com autonomia e protagonismo. Dessa maneira, todo o preparo prévio deste novo trabalhador, envolvendo o acolhimento, tem o intuito de qualificá-lo para sua atuação no território, que é a sua principal atribuição.

Consideramos que a estruturação do acolhimento tem um papel fundamental para a melhor compreensão do processo de trabalho em equipe e atuação no território, sob a lógica do Apoio Institucional, pois este foi e continua sendo um tema bastante debatido, estimulador de reflexões e provocador de discussões instigantes e enriquecedoras, tratando-se de um modus operandi (modo de trabalhar) que está diretamente ligado à nossa vivência cotidiana enquanto Apoiadores que vamos e buscamos nos tornar.

Considerando o acolhimento como parte da formação inicial do Apoiador, entendemos que o mesmo contribuiu fortemente para o nosso amadurecimento profissional, à medida que nos inseríamos no cotidiano de agendas internas e externas da equipe da Macrorregião CentroLeste. Hoje percebemos que o acolhimento colaborou para uma aproximação inicial do nosso campo de trabalho, no 
entanto ressaltamos que o tempo de trabalho na função Apoio potencializa um melhor conhecimento e apropriação do território de atuação, identificando as possibilidades de intervenção, em articulação com os diversos atores locais, valorizando a cartografia e análise dos indicadores de saúde e projetos estratégicos da Atenção Básica.

\section{Considerações Finais}

Podemos afirmar o quanto é relevante para o Apoiador, a opção da DAB pelo acolhimento de todo trabalhador recém-chegado, pois é a oportunidade que temos de compreender sobre: a organização e funcionamento da SESAB da Diretoria; o processo de regionalização no âmbito da saúde; o Apoio Institucional, as políticas de saúde e suas normatizações.

Visualizamos que os principais desafios hoje enfrentados para a efetivação da proposta de acolhimento ao trabalhador se referem à necessidade de desconstruir os paradigmas e referenciais que embasam a gestão tradicional e ter maior abertura dos profissionais para uma análise crítico-reflexivo dos seus processos de trabalho em equipe. Temos a expectativa de que o acolhimento a novos trabalhadores possa se tornar uma ferramenta institucionalizada em outros serviços da Secretaria da Saúde do Estado da Bahia, visando uma relação diferenciada do trabalhador com seu espaço de trabalho.

Portanto, a construção deste relato nos permitiu avaliar como as diferentes formas de inserção dos cinco componentes desta equipe ao longo dos anos e a nossa experiência no acolhimento se tornou um diferencial na nossa prática numa equipe de Apoio Institucional. Fica evidenciado nos nossos relatos individuais o quanto o acolhimento nos prepara e qualifica para a nossa atuação na lógica do Apoio, sendo uma etapa fundamental para conhecimento do espaço institucional ao qual pertencemos, compreendendo sua interrelação com os demais atores sociais que direta ou indiretamente lidam com as questões de saúde no âmbito da Atenção Básica.

Concluímos que o investimento no acolhimento, enquanto uma estratégia de formação e transformação do trabalhador que se insere na Diretoria, foi uma decisão acertada, na medida em que norteia a atuação dos novos trabalhadores, proporcionando maior segurança no enfrentamento aos desafios que fazem parte do cotidiano de quem atua como Apoiador Institucional.

\section{Referências}

BAHIA. Comissão Intergestores Bipartite da Bahia. Resolução CIB no. 132 de 20 de setembro 2007. Aprova o novo desenho do Plano Diretor de Regionalização do Estado da Bahia. Disponível em: < http://www2.saude.ba.gov. $\mathrm{br} / \mathrm{cib} /$ arquivos /Resolu\%C3\%A7\%C3\%B5es\% 20da\%20 ClB/2007/Resolu\%C3\%A7\%C3\%B5es\%202007.pdf>. Acesso em: 17 maio 2014.

BAHIA. Leis, etc. Decreto Estadual 14457 de 03 de maio de 2013. Aprova a Política Estadual da Atenção Básica. Diário Oficial da Bahia, Salvador, v.43, n. 21.130-21.131, 4-5 maio de 2013. Disponível em: < http://www.saude.ba.gov.br/ dab/PEAB_publicada.pdf>. Acesso em: 17 maio 2014. 
CAMPOS, G. W. S. Saúde Paidéia. São Paulo. Hucitec, 2003.

CAMPOS, G. W. S. Saúde Paidéia. São Paulo. Hucitec, 2007b. $185 p$.

CAMPOS, Gastão Wagner de Sousa; DOMITTI, Ana Carla. Apoio matricial e equipe de referência: uma metodologia para gestão do trabalho interdisciplinar em saúde. Cadernos de Saúde Pública, Rio de Janeiro, v. 23, n. 2, Fev. 2007a. Disponível em: < http://www.scielo.br/scielo.php?pid=S01 02311X2007000200016\&script=sci_arttext> Acesso em: 02 jan 2014.

CUNHA, M. A. E.; NASCIMENTO, M. A. M. A percepção dos trabalhadores sobre a construção de uma gestão participativa na Diretoria da Atenção Básica da Secretaria da Saúde da Bahia. Trabalho de Conclusão de Curso, 2009. Escola Estadual de Saúde Pública da Bahia, Escola de Enfermagem Universidade Federal da Bahia, Salvador.

\title{
O cotidiano do Apoio Institucional: o traba- Iho em equipe
}

\author{
Letícia de Moraes Falleiro
}

"Vou mostrando como sou E vou sendo como posso"1

A experiência que será contada neste livro começa em abril de 2010, quando fui trabalhar na Diretoria de Atenção Básica da Superintendência de Atenção Integral à Saúde da Secretaria da Saúde do Estado da Bahia (DAB/SAIS/SESAB)², como Apoiadora Institucional. $O$ trabalho em equipe que tenho vivenciado nestes últimos três anos tornou-se um desafio profissional e pessoal. Apresento aqui uma parte da história que vivi e as reflexões que tenho feito sobre os incômodos e aprendizados que surgem com este tipo de trabalho.

É importante ressaltar que minha primeira experiência de trabalho em equipe foi durante a Residência Multiprofissional em Saúde Coletiva ${ }^{3}$, de onde surgiu minha

${ }^{1}$ Trecho da música “Mistério do Planeta" (Moraes Moreira/ Galvão).

${ }^{2}$ A Diretoria de Atenção Básica compõe o organograma estrutural e funcional da Superintendência de Atenção Integral à Saúde (SAIS) da Secretaria da Saúde do Estado da Bahia.

${ }^{3}$ No Programa da Residência Integrada em Saúde da Escola de Saúde 
fascinação pelo trabalho coletivo. Eu trabalhava em uma Unidade Básica de Saúde, com uma equipe composta por oito categorias profissionais diferentes. Desde que entrei na $\mathrm{DAB} / \mathrm{SESAB}$, trabalho em equipe e, portanto, considero que trabalhar nesse espaço de Apoio Institucional está contribuindo para o amadurecimento e aperfeiçoamento de um processo, ao mesmo tempo em que constitui uma proposta totalmente diferente da primeira.

$\mathrm{Na} \mathrm{DAB} / \mathrm{SESAB}$, o Apoio Institucional é desenvolvido de forma mais estruturada pela Coordenação de Apoio e Desenvolvimento (COAD), que está organizada em nove equipes regionalizadas conforme o Plano Diretor de Regionalização do Estado (BAHIA, 2007). O número de componentes de cada equipe é variável e a organização do seu processo de trabalho é diversificada, conforme as características de cada Macrorregião, com o objetivo de otimizar a sua capacidade resolutiva.

O cotidiano de uma equipe de Apoio Institucional se divide entre as atividades na sede da SESAB, em Salvador e as ações no território de referência. Na sede, o trabalho consiste em atender às demandas por telefone; responder e-mails; responder processos de Auditoria e Ouvidoria do SUS/BAHIA, Controladoria Geral da União; analisar projetos de credenciamento de equipes no âmbito da Atenção Básica (ACS, ESF, ESB, NASF, etc.) ${ }^{4}$, participar de reuniões da $C O A D$ e de assembleias da DAB e de reuniões intersetoriais (conforme a demanda); participar de Grupos de Trabalho (BARROS, 2012) e de momentos de Educação Permanente.

Pública do Rio Grande do Sul, entre 2007-2008, os residentes atuavam como equipe multiprofissional nas Unidades Básicas de Saúde do município de Porto Alegre. Essas equipes eram compostas por médico, fisioterapeuta, psicólogo, assistente social, odontólogo, enfermeiro, nutricionista.

4 ACS: Agentes Comunitários de Saúde; ESF: equipe de Saúde da Família; ESB: equipe de Saúde Bucal; NASF: Núcleo de Apoio à Saúde da Família.
As ações no território constituem as chamadas "viagens de Apoio", em que temos a possibilidade de construir o vínculo com a Região de Saúde, ou seja, com as Diretorias Regionais de Saúde (DIRES) e com os municípios. Assim, nossas ações presenciais no território de referência são: visita técnica aos municípios; reuniões com equipe de técnicos da Atenção Básica das DIRES; Rodadas de discussão referentes a Atenção Básica ${ }^{5}$; participação em espaços diversificados com este tema, como Comissão Intergestores Regional (CIR), Oficina de pactuação das metas do Sistema do Pacto pela Saúde, reuniões intersetoriais, Conferências Municipais de Saúde. A participação nestas ações exige bastante dedicação técnica, pois é necessário estudo, planejamento, construção de metodologia, preparação de material, desenvolvimento, avaliação e acompanhamento de "Plano de Ação", e também dedicação pessoal dos Apoiadores que precisam ter disponibilidade para realizar constantemente viagens para o território.

Imagine a complexidade deste trabalho em equipe, cuja dinâmica inclui, além da convivência diária na sede, em Salvador, a convivência das viagens, em que passamos dias longe de casa, dividindo hábitos do cotidiano e sujeitos às condições locais de hospedagem e alimentação. Sei que alguns destes pontos parecem detalhes sem importância, e talvez sejam quando se viaja esporadicamente, não é? Entretanto, os Apoiadores da DAB viajam, em média, cada um, de três a cinco dias por mês, podendo variar conforme a demanda e a estrutura da equipe. Ou seja, trata-se de um processo de trabalho que interfere diretamente na organização da nossa vida pessoal de trabalhadores que somos, e por isso, o processo torna-se tão complexo.

A influência na vida pessoal, por exemplo, é um dos pontos que interfere na engrenagem da equipe. A todo

${ }^{5}$ Também chamados de Colegiados Microrregionais de Coordenadores Municipais de Atenção Básica. (BAHIA, 2013). 
o momento somos levados a confrontar nossos planos, nossos desejos e possibilidades com a demanda do trabalho e a disponibilidade de cada um $^{6}$.

Quando estava pensando em que experiência contar neste livro, olhava pra tudo isso e me sentia insegura, confusa, sem saber pra que lado ir, sem conseguir definir um objeto para o meu relato. Então, comecei a pensar nas questões que me mobilizam no trabalho, nas situações que me deixavam mais ou menos desconfortáveis.

"Eu estou integrada com a equipe? Será que eu consigo ouvir minhas colegas? Será que tive discernimento para identificar o momento de defender minha ideia e o de concordar com o outro? Preciso consultar toda a equipe ou posso decidir isso sozinha? Será que invadi o espaço da minha colega? Por que um tema específico me deixa tão afetada? Como as afinidades pessoais entre as pessoas interferem no trabalho? Será que consegui explicar? Será que entendi?"

Então percebi que nós, Apoiadores, no cotidiano do trabalho em equipe, falamos muito sobre o processo estruturado, sobre as demandas que recebemos, sobre a nossa produção, e pouco falamos sobre os nossos desafios ao lidar com a subjetividade do trabalho em equipe e do trabalho que exige viagens constantes.

Contar esta história é uma oportunidade de compartilhar o que tenho aprendido, pois a resposta para as perguntas acima, encontra-se mesmo no cotidiano. Além disso, a própria construção deste relato resgatou um processo que estava perdido em algum canto da 6 No artigo "Equipes de Trabalho: Fundamentos Teóricos e Metodológicos da mensuração de seus atributos", Puente-Palacios e Borba (2009, p.371) apresentam a definição de equipes de trabalho e afirmam que a especificidade das equipes de trabalho abrange a interação entre seus membros e o compartilhamento de suas crenças, pensamentos e atitudes. minha memória, e aos poucos pude relembrar, analisar, ressignificar e aprender. É como se reviver a experiência através da escrita fosse algo maior do que vivê-la.

\section{Um pouco da história que vivi na equipe de Apoio} Institucional da Macrorregião Sul

Contabilizo pelo menos seis composições diferentes da equipe no período de abril de 2010 a novembro de 2012:

\section{Quadro1:}

Composição da equipe sul entre abril de 2010 e novembro de 2012.

\begin{tabular}{|c|c|c|c|}
\hline EQUIPE & PERÍODO & CONTEXTO & MUDANÇA \\
\hline & Abril 2010 & $\begin{array}{l}\text { Macrorregiões Sul e } \\
\text { Extremo Sul: } 6 \text { Regiões } \\
-88 \text { municípios. } \\
4 \text { Apoiadores (A, B, } \\
\text { C, D). }\end{array}$ & $\begin{array}{l}\text { Marco inicial da } \\
\text { experiência: } \\
4 \text { Apoiadores (A, } \\
\text { B, C, D). }\end{array}$ \\
\hline & $\begin{array}{l}2^{\circ} . \\
\text { semestre }\end{array}$ & $\begin{array}{l}\text { Macrorregiões Sul e } \\
\text { Extremo Sul: } 6 \text { Regiões } \\
-88 \text { municípios. } \\
5 \text { Apoiadores (A, B, C, } \\
\text { D, E). } \\
\text { Período de Oficinas } \\
\text { Regionais de Avaliação } \\
\text { do ano com as DIRES. }\end{array}$ & $\begin{array}{l}\text { Sai Apoiadora "A"; } \\
\text { entra Apoiador } \\
\text { " } E \text { ". }\end{array}$ \\
\hline
\end{tabular}




\begin{tabular}{|c|c|c|c|}
\hline \multirow{4}{*}{ Sul } & $\begin{array}{l}1 \text { ㅇ. } \\
\text { bimestre } \\
2011\end{array}$ & $\begin{array}{l}\text { Macrorregião Sul: } \\
4 \text { Regiões - } 67 \\
\text { municípios. } \\
4 \text { Apoiadores (D, F, } \\
\text { G, H) } \\
\text { Período de } \\
\text { reestruturação das } \\
\text { equipes da COAD e } \\
\text { planejamento da DAB. }\end{array}$ & $\begin{array}{l}\text { Saem Apoiadores, } \\
\text { "B", "C" e "E" para } \\
\text { comporem outras } \\
\text { equipes. } \\
\text { Entram } 3 \text { novos } \\
\text { Apoiadores (F, G, } \\
\text { H); }\end{array}$ \\
\hline & $\begin{array}{l}2^{\circ} \text {. } \\
\text { semestre } \\
2011\end{array}$ & $\begin{array}{l}\text { Macrorregião Sul: } \\
4 \text { Regiões - } 67 \\
\text { municípios. } \\
4 \text { Apoiadores (D, F, } \\
\text { G, I) } \\
\text { Período de } \\
\text { desenvolvimento das } \\
\text { ações. }\end{array}$ & $\begin{array}{l}\text { Sai Apoiador “H”. } \\
\text { Entra Apoiador "I". }\end{array}$ \\
\hline & $\begin{array}{l}19 . \\
\text { semestre } \\
2012\end{array}$ & $\begin{array}{l}\text { Macrorregião Sul: } \\
4 \text { Regiões - } 67 \\
\text { municípios. } \\
3 \text { Apoiadores (D, F, I) } \\
\text { Planejamento das } \\
\text { ações. }\end{array}$ & Sai Apoiadora "G". \\
\hline & $\begin{array}{l}2 \text { o. } \\
\text { Semestre } \\
2012\end{array}$ & $\begin{array}{l}\text { Macrorregião Sul: } \\
4 \text { Regiões - } 67 \\
\text { municípios. } \\
5 \text { Apoiadores ( D, F, J, } \\
\text { K, L) } \\
\text { Período de } \\
\text { desenvolvimento das } \\
\text { ações. }\end{array}$ & $\begin{array}{l}\text { Sai Apoiador “I”. } \\
\text { Entram as } \\
\text { Apoiadoras “J”, } \\
\text { "K", "L". }\end{array}$ \\
\hline
\end{tabular}

Em 2010, a equipe era referência para as Macrorregiões Sul e Extremo-Sul do Estado da Bahia que abrangem oitenta e oito municípios. A Macrorregião Sul é formada por quatro
Regiões de Saúde (67 municípios): Jequié, Ilhéus, Itabuna e Valença; e a Macrorregião Extremo-Sul é formada por duas Regiões de Saúde (21 municípios): Teixeira de Freitas e Porto Seguro.

Em abril, com a minha chegada, éramos quatro Apoiadores (A, B, C, D). Fui muito bem acolhida. Meus colegas me repassaram, aos poucos, as informações mais gerais sobre cada região, o contexto socioeconômico e político, as ações já realizadas pela equipe, as dificuldades e potencialidades em cada local. Como não passei por um processo estruturado de acolhimento como temos hoje da $\mathrm{DAB}$, fui aprendendo no cotidiano, e as viagens ao território contribuíram para concretizar as informações que havia recebido dos meus colegas.

Logo que passei a fazer parte desta equipe, identifiquei dois pontos importantes do nosso processo de trabalho: garantir o fluxo de informações entre os integrantes e uma "uniformidade" de conduta, ou seja, que todos construíssem o mesmo tipo de resposta às demandas. Portanto, na tentativa de garantir a boa comunicação dentro da equipe, utilizamos as seguintes estratégias:

- realizar uma reunião diária da equipe, no início do expediente, para compartilhar as demandas e acontecimentos do dia anterior, com a intenção de que todos pudessem saber o que estava acontecendo na equipe e também para discutirmos coletivamente alguns temas importantes: processos de auditoria, planejamento das viagens, estudo de caso de algum município, etc.;

- utilizar um caderno para anotar as ocorrências daquele dia, ligações e os encaminhamentos de reuniões com gestores na DAB;

- analisar os processos (Auditoria, Controladoria Geral da União, credenciamento) em dupla, a fim de que 
as informações não ficassem centralizadas em um único Apoiador, e também para podermos trocar ideias e construir uma melhor resposta, a partir da discussão de caso com outro colega;

- realizar viagens em dupla, pois um Apoiador complementa o trabalho do outro e também dá suporte em situações mais críticas;

Destas estratégias, a única que não funcionou muito bem foi o caderno de ocorrências. Não constituíamos uma equipe com características metódicas, então era difícil manter processos bem estruturados por muito tempo. Por que há períodos em que o volume de trabalho fica muito intenso e com muitas demandas por atender, e por isso os registros de algumas ações acabam prejudicados. Além disso, as agendas de viagens tomam muito tempo e, manter processos estruturados nos períodos mais ativos, fica mais difícil.

Eu gostava muito das reuniões diárias no início da manhã. Como eu era nova na equipe, aprendia bastante quando trocava ideias com os colegas, pois podia ouvir a opinião de todos sobre o assunto. Assim, fui aprendendo a avaliar cada caso, a analisar os fatores relevantes para elaborar as respostas dos processos; onde procurar informações. Meus colegas tiveram muita paciência comigo quando precisava de ajuda principalmente para responder a processos estruturados, que exigem muita concentração, capacidade de análise e um conhecimento que somente vamos adquirindo com a prática.

Aproximadamente uns quatro meses depois, ganhamos um novo colega " $E$ ". O ritmo acelerado de trabalho que vivemos faz da integração de um novo componente na equipe um processo dinâmico, como "trocar o pneu com o carro em movimento"; aprende-se isso no cotidiano, à medida que as demandas vão surgindo, nós vamos respondendo e inserindo o novo colega nestes processos.

Foi assim que recebemos este novo integrante, que chegou no "olho do furacão", numa época em que nosso planejamento já estava na rua, e precisávamos dar continuidade ao que foi planejado e ao mesmo tempo acolher a demanda espontânea. Portanto, o novo Apoiador, quando entra neste contexto, precisa se integrar rapidamente ao processo de trabalho da equipe, dificuldade compensada pelo seu grande contato com o território (o que proporciona a concretização de muitas informações), pela intensidade das agendas de viagem.

Logo após, a saída da colega " $\mathrm{A}$ " mexeu bastante na equipe, como aqueles jogos de estratégia em que movimentar uma única peça altera completamente a dinâmica do jogo. Ocorre que, quando se trata da subjetividade do trabalho em equipe, "um mais um não é igual a dois", pois existem várias possibilidades de combinações entre seus membros. Nesta interrelação, cada um desempenha um papel individual e coletivo. Portanto, quando se mexe em um membro da equipe, a mudança afeta a todos.

Além dessa condição, há ainda o sentimento de luto pela ausência de um colega. Essas interações podem gerar uma diversidade de reações, e é preciso saber lidar com elas para que a equipe supere, cada membro a seu tempo, a mudança que aconteceu. Identificar este processo dentro da equipe é muito importante para compreendermos as mudanças que ocorrem nos outros colegas e em nós mesmos, e também para acolhermos o novo integrante de forma tranquila e minimizar as projeções ou expectativas, preservando o processo de trabalho.

Nesta "primeira fase" vivenciada por mim, é que surgiram as primeiras perguntas: "Eu estou integrada com 
a equipe? Como as afinidades pessoais entre as pessoas interferem no trabalho? Preciso consultar toda a equipe ou posso decidir isso sozinha? Será que invadi o espaço da minha colega"?

Muitas vezes me sentia deslocada dentro da equipe porque os outros colegas já conviviam há muito tempo, e eu ficava com a sensação de que era excluída. Então passei a me perguntar qual a influência das afinidades pessoais no nosso trabalho? É claro que teremos uma maior empatia por uma ou outra pessoa, e isso é normal, o que me intriga é saber até que ponto isso facilita ou atrapalha o cotidiano.

Quando viajamos juntos, por exemplo, é melhor que estejamos com alguém com quem nos sentimos mais à vontade, pois conviveremos alguns dias com aquela pessoa. Entretanto, é importante ficarmos atentos para que isto não dificulte a interação com as outras pessoas da equipe, a ponto de atrapalhar o nosso trabalho.

Rapidamente, a primeira lição que tive foi de que a comunicação entre todos da equipe é um fator elementar para um bom trabalho, pois evita que as subjetividades distorçam alguns acontecimentos e criem "fantasmas" de discórdia e desafeto. Por outro lado, a comunicação também é importante para garantir o fluxo de informações e assim, possibilitar que todos na equipe possam responder às demandas, sem que se dependa da presença de um ou outro colega para respondê-las.

\section{A divisão da equipe}

No início de 2011, ocorre uma reorganização das equipes da COAD, e a equipe é dividida em Equipe Sul (quatro Regiões de Saúde) e Equipe Extremo-Sul (duas Regiões de Saúde). Eu permaneci como Apoiadora "D" da Macrorregião Sul, e os outros três integrantes " $B$ ", " $C$ ", " $E$ ", foram remanejados para outras equipes.

No início, pensei que estivesse preparada para viver outra história, com uma nova equipe, pois gosto de mudanças. De repente, durante a espera por saber quem seriam meus novos colegas, percebi que o papel de anfitriã da equipe caberia a mim, e me senti tensa e insegura. Do dia para a noite, passei de novata para a Apoiadora mais antiga de referência da região, e que acolheria os novos colegas e apresentaria a eles as informações sobre a Macrorregião e o processo de trabalho da equipe.

A Equipe Sul passa então a ter quatro integrantes $(D, F, G, H)$. Muito me surpreendi por ter que desenvolver este papel na equipe, pois eu me considerava ter pouca experiência para desenvolvê-lo. Isso "mexeu" comigo, porque me sentia insegura.

Neste processo, outras perguntas surgiram: Como manter registrada a história do trabalho desenvolvido naquela região? Como garantir o registro e continuidade de um trabalho, apesar das mudanças?

Desde o início dessa nova composição da equipe, fizemos reuniões para o repasse das informações sobre o território da Macrorregião: o contexto político, social, econômico e cultural; a interação com as DIRES e com os municípios; os processos estruturados; a organização da equipe, ou seja, como costumávamos trabalhar na extinta equipe $E$. 
Naquele momento, percebi o quanto me incomodava "mexer" no processo de trabalho da equipe. Se eu havia identificado mudanças quando mudou um colega, imagine com uma nova equipe! Novas pessoas, com diferentes interesses no trabalho, com diferentes olhares, com diferentes crenças, ritmos e história de vida. Era preciso que eu me "desterritorializasse" para poder acompanhar o novo grupo. E me perguntava: "Qual é o limite entre estar aberta para o novo e preservar o que foi construído pela equipe anterior"? Esse foi um grande desafio.

Por ter uma experiência anterior, eu muitas vezes acabava defendendo a manutenção da forma de trabalhar da equipe E: "Se eu estou dizendo que dessa forma funciona, porque eles querem mudar"? "Se está dando certo assim, por que mudar"? Muitas vezes julguei meus colegas novos por considerar que eu, pela experiência anterior, deveria ter minhas sugestões acatadas pelos novatos.

A partir daquele momento, passei a entender a resistência a mudanças expressada por alguns colegas que trabalham há mais tempo na SESAB. Nem todos viam a saída e a chegada de novas pessoas como algo bom, e sempre achei isso ruim, e considerava essa conduta como um conservadorismo; não aceitar essa condição dinâmica da constituição da equipe da DAB.

Todavia, entendi que nem sempre quem fica está disposto a mudar. Há o conforto da estabilidade, de manter tudo como está, de seguir uma rotina a qual já estamos acostumados. Por outro lado, há o excesso de ansiedade de quem chega cheio de ideias novas, cheio de energia para trabalhar num lugar novo, e no intuito de colaborar, acaba desconsiderando as experiências anteriores. Cada um que chega considera que tem uma forma melhor de fazer cada coisa, de organizar as pastas, de arquivar e responder os processos. Daí, se não soubermos identificar o momento de defender nossa ideia, e o momento de aceitar a ideia do outro, o diálogo entre quem está e quem chegou pode gerar tensão na equipe.

Em qual momento eu estive certa ou errada? Impossível saber! Em algum momento precisamos defender nossas ideias, em outro abrir mão delas. Como saber a dose certa desse tempero? Somente experimentando!

Mesmo considerando que pensar sobretudo no coletivo deve ser um princípio do trabalho em equipe, este é também um grande aprendizado. De qualquer forma, teremos sempre que lidar com as motivações pessoais, com a história de vida que cada pessoa da equipe traz consigo, e com as características individuais de cada um.

Algumas vezes, o trabalho em equipe nos dá a sensação de que perdemos nossa individualidade, de que o produto do trabalho não foi produzido por nós. Claro, o produto do trabalho sempre será da equipe, acontece que, muitas vezes, não queremos nos responsabilizar também pelo trabalho do outro e agimos como se fosse assim: "bem, a ideia foi dele, ele que faça" ou "se der errado, eu não tenho nada a ver com isso". Ora, quando se trata de um trabalho em equipe, os ônus e os bônus são de todos.

\section{De volta à nova composição da equipe...}

Como éramos uma nova equipe, cujos componentes não se conheciam, precisávamos encontrar nosso equilíbrio, criar vínculo, confiança, e organizar um processo de trabalho ao qual todos conseguissem se adaptar e desenvolver. Organizar um planejamento anual para a equipe, muito nos ajudou. A partir do planejamento da DAB, conseguimos 
definir nossas ações em cada Região contemplando as suas singularidades e a continuidade de algumas já iniciadas.

Nessa composição, tínhamos dificuldade de definir consenso dentro da equipe. Tínhamos muito respeito um pelo outro, pessoalmente, mas cada debate era muito demorado, e gerava bastante tensão e gasto de energia. Foi um período muito intenso em relação à demanda de trabalho, e essa intensidade reverberou dentro da equipe. Metade de nós já estava familiarizada com o trabalho e a outra metade ainda estava se adaptando. Então, vivíamos uma disputa constante entre o novo e o velho; o pessoal, o profissional e o institucional; a minha ideia ou a do outro. Mesmo assim, ficou comigo a sensação de que, nos momentos mais difíceis, estávamos todos juntos.

Mais ou menos após uns quatro meses, nova mudança na equipe: Apoiador " $\mathrm{H}$ " sai e logo depois recebemos um novo colega "I", num período de finalização das ações no território e início da avaliação e planejamento. No início de 2012, "G" sai da equipe para assumir outra função dentro da DAB. E então, éramos três.

Confesso: é angustiante ver sua equipe e consequentemente seu processo de trabalho sofrendo tantas mudanças em pouco tempo! Neste período, isso significou apresentar o processo de trabalho da equipe, apresentar o território, aguardar o tempo de adaptação do novo Apoiador, apoiá-lo. E daí começar tudo de novo, em menos de cinco meses!

Fica a sensação de que estamos sempre reiniciando um trabalho, sem conseguir dar continuidade às ações, em razão de que, quando muda um Apoiador, isso faz com que o fluxo de algumas ações que foram disparadas fique lento, e até seja interrompido, para que ele se adapte e se aproprie do trabalho; tudo isso exige bastante dedicação de quem já está há mais tempo.
É preciso conviver com esta sensação de não conseguir finalizar uma ação com a mesma equipe, de estar sempre recomeçando, e saber equilibrar a necessidade de mudança e de manutenção de algumas condições já estruturadas na equipe. $E$, veja bem, esse processo todo compreende o repasse de informações sobre: a Macrorregião em geral; os municípios e as DIRES; a organização da equipe; os processos estruturados que temos que responder; o planejamento da equipe.

A princípio, pode parecer simples, porém, quando se trata da organização da equipe, dos processos estruturados e do planejamento, é preciso dar espaço para o novo integrante se apropriar e também contribuir nestes temas. Daí, precisamos nos dedicar a discutir coisas do 'miudinho' do trabalho, que interferem bastante no cotidiano. Por exemplo:

1. Os arquivos da equipe, que estão organizados na rede opala ${ }^{7}$ da DAB: Algumas pessoas se adaptam a forma como os arquivos já estão organizados, mas há pessoas que querem mudar o nome das pastas, ou dos arquivos, ou criar novos, excluir alguns. Ou seja, cada um tem uma forma de se organizar, e por isso, esse debate pode ocupar um bom tempo de uma reunião da equipe, e deve ser assim. Sabem por quê? Se não definirmos como arquivar cada documento, quando você menos perceber, a pasta da equipe na rede está um verdadeiro frankenstein, e você encontra pastas repetidas, descobre que algumas foram excluídas quando você mais precisa, encontra arquivos duplicados em pastas diferentes, e de repente, percebe que está demorando meia hora do seu tempo procurando um arquivo.

2. A organização da equipe: Considerando que cada equipe apoia uma Macrorregião que está subdividida em

${ }^{7}$ Rede de computadores utilizada para armazenar os documentos da DAB. 
Regiões de Saúde, cada Apoiador se dedicará exclusivamente a uma única Região, ou todos apoiarão todas as Regiões igualmente? Será uma divisão fixa ou haverá um rodízio dentro da equipe? Viajar sozinho, em dupla, ou toda a equipe junta? Essa divisão da equipe é a que gera mais polêmica quando entra um Apoiador novo. Geralmente, estes têm muita expectativa por conhecer o território.

Não há uma definição em relaçãoà melhor distribuição dos Apoiadores, porque há muitas variáveis que interferem nesse tema. No caso da equipe Sul, trabalhamos geralmente com um Apoiador de referência para cada Região, mas com a ideia de compartilharmos a responsabilidade daquele território, pois todas na equipe devem estar preparados para responder às demandas que surgem, independente de serem do território de sua referência. Entretanto, toda a vez que chega um Apoiador novo essa organização é questionada, e muitas vezes me peguei "respirando fundo" pra entender que, de fato, é importante que sejamos questionados, pois é uma forma de avaliação do nosso trabalho. Mas nem sempre estamos abertos pra isso.

3. A organização dos fluxos e definição das ferramentas utilizadas pela equipe: como vamos garantir que as informações não estejam disponíveis a toda a equipe? Reunião ao fim do dia? Reunião uma vez por semana? Reunião no início do dia? E-mail? Planilhas? Como e onde vamos registrar as informações sobre a nossa região? Como monitorar? Quais dados são importantes? Onde arquivar as informações? E como fica a divisão de tarefas?

Bem, se você leu até aqui já deve ter elaborado algumas respostas para cada uma dessas perguntas. Mas, se você já trabalhou em equipe, sabe que cada integrante tem uma boa solução para elas, e o quanto é difícil encontrar uma forma de todos trabalharem juntos utilizando as mesmas ferramentas, e mais difícil ainda é saber quais utilizar.
Para que nossa equipe pudesse trabalhar de forma harmônica, respondendo às diferentes demandas, e que todos os integrantes tivessem a mesma conduta, foi necessário passar por várias reuniões até conseguirmos nos organizar coletivamente.

Encontrar o ponto de equilíbrio é um processo que não se encerra em reuniões. É preciso dar tempo ao tempo, para que a convivência no cotidiano produza em nós a consciência de um grupo, lembrando que o resultado não é tão somente a soma de cada uma das partes, é também outro produto. Nesse processo é que se produz uma sensação de confusão entre a nossa individualidade e a coletividade.

No início de 2012, quando passamos a ter três pessoas na equipe, logo após o período do planejamento das ações do ano, tínhamos um cronograma a cumprir, com ações contínuas, interdependentes, e optamos por dar continuidade ao "Plano de Ação", pelo menos em relação às ações estratégicas.

Essa escolha gerou uma sobrecarga de trabalho. Chegamos a viajar três semanas por mês, pois éramos três Apoiadores para quatro Regiões de Saúde (sendo que um de nós estava fazendo um curso de pós-graduação, limitando a sua disponibilidade para viagens).

As Oficinas para implantação da Linha de Cuidado Materno-Infantil exigiam muito tempo de dedicação (estudo, preparação, desenvolvimento, avaliação). Trabalhamos um ano inteiro num ritmo intenso, com foco no cronograma pactuado. Cumprimos o que estava planejado e nos submetemos a um nível de estresse alto; mal chegávamos de uma viagem, já partíamos para outra.

Além da sobrecarga de volume de trabalho, havia também a intensa convivência da equipe durante as 
viagens. Muitas vezes, acabávamos dividindo também nossas preocupações e problemas pessoais com os colegas, pois passávamos mais tempo viajando do que em casa.

Atualmente, por meio da elaboração dos relatórios trimestrais deações da equipe, identifico um comportamento cíclico do trabalho do Apoio na DAB. Geralmente, o período de dezembro a março é o que apresenta menos demandas externas (de ações no território), e constitui-se de ações de avaliação e planejamento. Entre os meses de abril a novembro, há uma maior demanda e oferta, pois as ações disparadas nos territórios precisam de planejamento ao seu seguimento.

É com essa densidade e intensidade do trabalho que muitas tensões se revelam. Estamos todo o tempo sob tensão. As ações estão "na rua", a todo o momento somos procurados e solicitados a dar respostas, encaminhamentos, identificar alternativas e soluções, e nem sempre temos tempo, por exemplo, de discutir tudo o que acontece com os outros colegas. Geralmente, nesta fase, deixamos em segundo plano alguns fluxos e planilhas utilizados pela equipe, para darmos conta da rotina. Isso causa certa desordem no nosso processo de trabalho, e quando chega o tempo de calmaria, a primeira coisa que fazemos é sistematizá- lo.

O cansaço pode ser um fator que dispara processos de subjetivação que podem aumentar ainda mais a tensão da equipe. Se a equipe não estiver bem harmonizada, se não houver confiança e um mecanismo de compartilhamento de informações, outros fatores, como ansiedade, autocrítica, insegurança, desconfiança, vaidade, podem gerar tensões exacerbadas e muitas vezes injustificadas.

Nessas circunstâncias, é preciso lidar com nossos próprios pensamentos, sentimentos, com afetações de origem pessoal que podem influenciar nossa conduta.
Percebo que, quanto mais claro se tornou pra mim este processo interno, mais eu compreendi também as ações e reações dos meus colegas, e assim, muitas tensões se dissolveram. E estes são processos que podem ser individuais ou coletivos, dentro pra fora, de fora pra dentro. Em algum momento, toda a equipe passa por isso, em maior ou menor intensidade, dependendo também da história pregressa de cada um.

No fim do ano de 2012, nova mudança: Apoiador "l" sai da equipe, e logo surgem mais três novos integrantes (J, K, L). Como havia algumas ações a serem concluídas, novamente "trocamos o pneu com o carro andando", e assim os novatos foram aprendendo sobre o nosso trabalho.

\section{Considerações Finais}

“(...) E pela lei natural dos encontros. Eu deixo e recebo um tanto." 8

Nestes dois anos, foram tantas experiências com tantas pessoas diferentes, que o aprendizado extrapolou o âmbito profissional. E de fato, acredito que o trabalho em equipe proporciona isso, principalmente quando estamos num espaço em que temos mais liberdade para nos desenvolvermos como grupo e como parte dele.

Existem algumas características do trabalho de Apoio Institucional na DAB que são relevantes para a construção singular dessa experiência: a convivência próxima pelo cotidiano de viagens; a construção coletiva das propostas

${ }^{8}$ Trecho da música "Mistério do Planeta” (Moraes Moreira/ Galvão). 
de metodologias de trabalho; quem planeja é quem executa e avalia; cogestão (CAMPOS, 2007).

A integração desses fatores com as questões subjetivas do trabalho em equipe, como: relação entre individualidade e coletividade (um mais um não é igual a dois); a história de vida que cada um traz consigo; a relação que cada pessoa tem com o trabalho; interfere diretamente na dinâmica da equipe, e pode levar uma composição harmônica, mas também pode aproximar pessoas com perfis incompatíveis.

Entre tudo o que aprendi até hoje neste trabalho em equipe, finalizo esse relato destacando três pontos que a meu ver são pilares para o desenvolvimento de uma equipe:

1-a confiança no trabalho do outro;

2-quando se trabalha em equipe, o que parece óbvio pra mim pode não ser óbvio para o outro;

3- a boa comunicação e o bom fluxo de informações, com processos estruturados que garantam o registro das ações é muito importante para garantir a continuidade do trabalho.

Por fim, a rotatividade de Apoiadores é constante na DAB e, portanto, estamos sempre num movimento cíclico de saídas e chegadas de colegas, de encontros, acolhimentos, aprendizados, despedidas. Nosso desafio é garantir que este movimento seja transformador para todos, e que o processo de trabalho flua, apesar do contexto de descontinuidade.

\section{Referências}

BAHIA. Comissão Intergestores Bipartite da Bahia. Resolução CIB no. 132 de 20 de setembro 2007. Aprova o novo desenho do Plano Diretor de Regionalização do Estado da Bahia. Disponível em: < http://www2.saude.ba.gov. br/cib/arquivos /Resolu\%C3\%A7\%C3\%B5es\% 20da\%20 ClB/2007/Resolu\%C3\%A7\%C3\%B5es\%202007.pdf >. Acesso em: 17 maio 2014

BAHIA. Leis, etc. Decreto Estadual 14457 de 03 de maio de 2013. Aprova a Política Estadual da Atenção Básica. Diário Oficial da Bahia, Salvador, v.43, n. 21.130-21.131, 4-5 maio de 2013. Disponível em: < http://www.saude.ba.gov.br/ dab/PEAB_publicada.pdf>. Acesso em: 17 maio 2014.

CAMPOS, G. W. S. Saúde Paidéia. São Paulo. Hucitec, 2007. $185 \mathrm{p}$.

PUENTE-PALACIOS, Katia; BORBA, A.C. P. Equipes de trabalho: fundamentos teóricos e metodológicos da mensuração de seus atributos. Avaliação em psicologia., Porto Alegre, v. 8, n. 3, dez. 2009. Disponível em: <http://pepsic. bvsalud.org/scielo.php?script=sci_arttext \&pid=S167704712009000300009\&lng=pt\&nrm=iso>. Acesso em 17 maio 2014 


\section{De Apoiadora à coordenadora: uma jornada de autoconhecimento e gestão de coletivos no Apoio Institucional vivenciada na Bahia}

Rebeca Silva de Barros

A função de coordenação não é fácil para ninguém; assim penso. E comigo não foi diferente! Imaginar-me como coordenadora do Apoio Institucional na Diretoria de Atenção Básica $(D A B)^{1}$ me causou muita ansiedade!

Desse modo, este texto é uma oportunidade de socializar minha experiência vivida no período de março de 2012 a setembro de 2013 neste papel. E, para melhor apresentar meu relato, dividirei minha jornada em três períodos: os primeiros cinco meses, finalização do primeiro ano e os últimos nove meses. Farei esta divisão assumindo o risco de perder alguns detalhes, entretanto, meu compromisso ao redigir estas linhas é de ater-me no que foi mais significativo para mim e que se tornou chave para meu aprendizado profissional. De antemão, posso afirmar que sistematizar a vivência que estou tendo em "ato"

${ }^{1}$ A Diretoria de Atenção Básica compõe o organograma estrutural e funcional da Superintendência de Atenção Integral à Saúde (SAIS) da Secretaria da Saúde do Estado da Bahia.

${ }^{2} \mathrm{Na}$ DAB, é por meio do trabalho-vivo (MERHY, 2005) que sanitaristas 
não foi uma tarefa fácil por que mobiliza em mim muitos sentimentos e reflexões. Contudo, mantive firme meu propósito de registrá-la, pois acredito que poderá contribuir com a prática de muitos colegas que têm corajosamente encarado a missão de coordenar equipes de saúde na Atenção Básica.

\section{O Apoio Institucional: breve resgate}

No cenário nacional, um dos maiores desafios do Sistema Único de Saúde (SUS), após vinte e cinco anos de sua criação pela Constituição Federal de 1988, tem sido a necessidade de inovação no campo da gestão em saúde e, nas ações e posturas que marcam a relação entre os três entes federativos. Neste cenário, surge o Apoio Institucional como opção contra hegemônica frente aos modelos de gestão mais tradicionais marcados pela excessiva burocratização, pelo autoritarismo e pela tomada de decisão de forma verticalizada.

O Apoio Institucional foi implantado na Bahia, no ano de 2007, como um dos eixos estruturantes da Política Estadual de Atenção Básica (PEAB) baseando-se nas diretrizes de democracia institucional e na autonomia dos sujeitos. Esta estratégia organizacional no âmbito do Estado da Bahia propunha, portanto um modo de agir que buscava mais horizontalidade na relação Estado-município e nos encontros entre gestores-gestores, gestores-trabalhadores e gestores-usuários (BAHIA, 2013).

Minha trajetória na DAB se inicia em março de 2008, cirurgiã-dentista, vinda de São Paulo, que recentemente

$\overline{\text { vão se tornando apoiadores, ou seja, a formação dos profissionais dá-se }}$ em "ato"! havia finalizado o curso de especialização em saúde coletiva, sob contrato cujo objetivo era trabalhar como Apoiadora Institucional na equipe de Apoio de referência para as Macrorregiões Leste e Nordeste do Estado da Bahia. Encarei com muita ansiedade toda a novidade que cercava o modelo de gestão da DAB que propunha uma nova estratégia organizacional que tomava como referência o Método Paidéia, proposto por Campos (2007), como metodologia para a ampliação da capacidade de análise e de cogestão dos sujeitos, ou seja: resgatando a noção de valor de uso dos serviços de saúde produzidos pela gestão e/ou assistência; reafirmando a possibilidade de que os sistemas de saúde contribuíssem para a constituição dos sujeitos; reformulando as práticas de gestão do trabalho, quando considera que a gestão é produto de uma interação entre pessoas e produz efeitos sobre o modo de ser e de proceder de trabalhadores e de usuários das organizações.

\section{De Apoiadora à Coordenadora}

Em meados de março do ano de 2012, a Fundação Estatal Saúde da Família (FESF-SUS) acabara de assinar um Contrato de Programa junto à Secretaria de Saúde do Estado da Bahia (SESAB) com o objetivo de desenvolver - Projeto Apoio Institucional para implementação do Programa Nacional de Melhoria do Acesso e da Qualidade da Atenção Básica ${ }^{3}(P M A Q-A B)$ na Bahia entendido como a gestão, operacionalização e execução das ações e

${ }^{3}$ Programa Nacional de Melhoria do Acesso e da Qualidade da Atenção Básica (PMAQ-AB) e o Incentivo Financeiro do PMAQ-AB, denominado Componente de Qualidade do Piso de Atenção Básica Variável - PAB Variável foram instituídos pelo Ministério da Saúde por meio da Portaria MS no1654, de 9 de julho de 2011. 
serviços especializados em Apoio Institucional e Matricial para qualificação e fortalecimento da gestão municipal e regional, bem como no fomento da institucionalização dos processos de avaliação e monitoramento na Atenção Básica, nos âmbitos da gestão e do cuidado neste nível de atenção.

Apesar da estrutura da SESAB contar com um corpo de trabalhadores concursados efetivos da instituição, para trabalhar na perspectiva do Apoio Institucional era preciso contratar uma equipe de Apoiadores ${ }^{4}$ e dimensionar estrutura administrativa para atender adequadamente às demandas da Atenção Básica. É nesse contexto que chego à função de "gerente de Apoio Institucional" - cargo previsto no contrato de programa referido acima e que deveria ser assumido por alguém que já compusesse a equipe de Apoiadores Institucionais da DAB, com a finalidade de não haver descontinuidade do trabalho já iniciado.

Para isso, os Apoiadores Institucionais (efetivos e contratados) se reuniram para definir quem ocuparia esse cargo. Fui indicada pelo grupo juntamente com outra colega. Debatemos entre nós quem estaria disposta a assumir essa "missão" e chegamos à conclusão que, naquele momento, eu seria a pessoa mais indicada visto que em nossa reorganização no processo de trabalho eu já sairia de minha equipe para assumir o Apoio em outra macrorregião, ou seja, passaria inevitavelmente, por um processo de desterritorialização. Já a outra colega desejava investir seus esforços na execução do planejamento macrorregional que construíra junto à equipe e às Diretorias Regionais de Saúde de referência.

\footnotetext{
${ }^{4}$ É bem verdade que esse não foi o primeiro contrato que assumíamos com o objetivo de ampliar a equipe. Desde 2007, alguns dos Apoiadores Institucionais e matriciais da DAB passaram por contratos de consultoria com vínculos como por exemplo: Projeto Saúde Bahia e Projeto de Expansão e Consolidação Saúde da Família (PROESF).
}

Aqui vale ressaltar um fato curioso, fui indicada para ocupar esse novo cargo pois a equipe de Apoiadores Institucionais via em mim uma pessoa bastante organizada, criativa, tranquila, "aquela que se dá bem com todo mundo", com bons conhecimentos em tecnologias de informação e comunicação e, aquela que poderia ativar atividades de Educação Permanente. Como eu me via? Uma pessoa ansiosa, com pouco conhecimento técnico, tímida, introspectiva, criativa, relativamente organizada e com um razoável conhecimento sobre tecnologias de informação e comunicação.

O contrato entraria em vigor e eu iniciaria uma das caminhadas mais bonitas que me levaram ao autoconhecimento. Sim! Disso eu tinha certeza àquela altura dos acontecimentos, eu estava disposta a empreender uma busca de mim mesma e não seria fácil, pois de um dia para o outro passei de Apoiadora à coordenadora, sem nenhum curso de especialização em gestão de pessoas ou planejamento estratégico! Apesar da insegurança inicial, essa seria, sem dúvida, uma oportunidade para meu aprimoramento profissional.

\section{O Apoio Institucional no contexto da DAB e as primeiras reflexões sobre a função "coordenação"}

No contexto da DAB, o Apoio Institucional se desenvolve na Coordenação de Apoio e Desenvolvimento (COAD) a qual é composta por nove equipes de Apoio Institucional organizadas de forma regionalizada de acordo com o Plano Diretor de Regionalização $\neg P D R \neg$ (BAHIA, 2007) a fim de atender aos 417 municípios baianos, divididos em nove Macrorregiões e 28 Regiões de Saúde. Atualmente, 
esta coordenação conta com dois coordenadores, quatro trabalhadores de apoio administrativo e 42 Apoiadores Institucionais.

No desenvolvimento do Apoio, o que se espera desses trabalhadores é que cumpram com determinadas atribuições propostas por Campos (2007) para o pleno desenvolvimento deste trabalho. Dentre elas destacamse a capacidade de: construir rodas de discussão ativando espaços coletivos que favoreçam a interação entre sujeitos, a análise de situações e a tomada de decisão, entre outros; incluir em suas análises as relações de poder, de afeto e os conhecimentos em circulação num determinado grupo; trabalhar com metodologias ativas que tanto ofertem ferramentas externas como valorizem as demandas do grupo apoiado; pensar e fazer junto com as pessoas e não em lugar delas.

Bertussi (2010) ainda complementa as atribuições da função Apoio quando indica que o Apoiador deve ter ferramentas que favoreçam: a negociação/compatibilização de interesses distintos num mesmo grupo; a produção de conexão, considerando as singularidades, a diversidade e mobilidade dos agenciamentos; a facilitação de processos que contribuam para colocar as potências dos sujeitos Apoiadores em evidência; a ação, a partir do cotidiano, observando os movimentos do grupo e seu contexto, estando sempre aberto à escuta e; a ação pedagógica, tomando o mundo do trabalho como matéria prima para o processo de ensino-aprendizagem.

Ao observar tais pontos, foi inevitável questionar: qual trabalhador da área de saúde estaria preparado para assumir tal função no SUS?! Sem dúvida alguma, na minha opinião, não há graduações ou pós-graduações que preparem profissionais com esse perfil. Na DAB, é por meio do trabalho-vivo (MERHY, 2005) que sanitaristas vão se tornando Apoiadores, ou seja, a formação dos profissionais dá-se em "ato"! Entretanto, ao constatar isso, do lugar de coordenação, uma outra inquietação começou a me instigar: se a formação de Apoiadores dá-se em ato, qual o papel do coordenador nesse processo?

\section{Iniciando a jornada de coordenadora}

Iniciei minha jornada ${ }^{5}$ com a clara intenção de investir na Educação Permanente da equipe e num acompanhamento mais cotidiano de suas atividades. Afinal de contas, eu tinha vindo do Apoio Institucional e sentia a necessidade de ter a coordenação mais próxima, poder compartilhar as experiências exitosas e desabafar quando as atividades planejadas não alcançavam o resultado esperado. O trabalho iniciou-se com duas pré-tarefas: identificar as principais atividades desenvolvidas na coordenação e, investir em ferramentas de comunicação entre coordenação e equipes.

Em relação à comunicação, optou-se por criar uma conta de e-mail para a coordenação de forma que todos os diálogos virtuais com equipes, Apoiadores, municípios e Diretorias Regionais de Saúde ficassem registrados num único endereço eletrônico e, desenvolver uma agenda compartilhada utilizando a ferramenta do Google Agenda $^{\circledR}$. Nenhuma equipe foi obrigada a aderir à agenda on line; esta era uma proposta da coordenação e lá seriam visualizadas e

\footnotetext{
${ }^{5}$ Assumi meu posto de gerente de Apoio Institucional pelo contrato de programa e fiz parceira com o Coordenador da COAD, na época, José Cristiano Soster. Como a equipe de Apoiadores é bastante grande, é preciso que duas pessoas se dediquem à função de coordenação pois caso contrário muitas demandas ficariam represadas. Este modelo de trabalho com dois coordenadores já estava em vigor quando assumimos este papel na instituição.
} 
disponibilizadas todas as agendas coletivas.

Instituir estas duas ferramentas facilitaram muito o meu processo de trabalho porque tinha organizado boa parte do fluxo de comunicação que evitava a sobreposição de tarefas na coordenação e, o envio de comunicados repetitivos sobre data e local de encontros, eventos e reuniões. Afinal de contas, quando se lida com um contingente tão grande de trabalhadores numa estrutura tão complexa que é a secretaria estadual de saúde investir em comunicação não é luxo; é necessidade.

Após atualizar os meios de comunicação, parti para a outra pré-tarefa que tinha como foco identificar as principais atividades desenvolvidas na coordenação. Qual não foi minha surpresa ao perceber que muito mais de $50 \%$ da minha nova agenda seria composta por tarefas administrativo-burocráticas como supervisão/ gestão de pessoas e gerenciamento de tarefas com fluxo bem estruturado.

No que diz respeito à supervisão/ gestão de pessoas, destaco: acompanhamento de frequência diária, pedidos de férias e licenças dos Apoiadores; entrevistas e acolhimento de novos trabalhadores; organização e (re)composição das equipes.

No tocante ao gerenciamento, ressalto: as respostas às demandas de Ouvidoria, Auditoria, Controladoria Geral da União (CGU), Gabinete da SESAB, superintendência; validação de ofícios e outros documentos institucionais; validação de solicitação de passagens e diárias para deslocamento dos Apoiadores para o interior do Estado; organização de reuniões da COAD; representações das equipes de Apoio e Diretoria em reuniões/ eventos; organização de Atividades de Educação Permanente.
Os Primeiros Cinco Meses: Sentindo o peso da responsabilidade

Passei os primeiros cinco meses extremamente envolvida com essas tarefas, e dentre elas as que mais me angustiavam vem seguir.

\section{Entrevista e acolhimento de novos trabalhadores}

Pelo contrato de programa estava prevista a lotação de 15 trabalhadores concursados da FESF-SUS para trabalharem como assistentes de Apoio Institucional na DAB. Vivi, então, um momento bastante novo e desafiador: entrevistar pessoas e identificar se estas reuniam habilidades mínimas que as colocariam em cena no Apoio Institucional.

Pela primeira vez, senti o peso da responsabilidade sobre os meus ombros. E com isso vieram os primeiros questionamentos: se eu não soubesse fazer as perguntas certas? Como perceber as habilidades desses sujeitos e construir com eles a capacidade para o desenvolvimento da função Apoio? Como qualifica-los para o trabalho no Apoio Institucional? Que tipos de experiências ou bagagens deste trabalhador devem ser valorizadas? Que tipo de apoio o coordenador teria que dar para este "novo" trabalhador? Que atividades de Educação Permanente seriam necessárias para qualifica-los? Como avaliar o seu desempenho?

Nestes primeiros cinco meses, entrevistei mais de 20 trabalhadores concursados FESF-SUS ${ }^{6}$. Muitos deles

${ }_{6}$ Para constituir esta equipe, o concurso foi um pré-requisito. No Plano de Empregos Cargos e Salários da FESF-SUS os empregos da área da saúde podem ser nomeados para desempenhar na instituição a chamada Função Estratégica de Gestão, na qual se encontra o cargo de Assistente de Apoio Institucional. Só são nomeados para essa função concursados selecionados por meio de entrevista presencial ou virtual pelo Skype e análise de currículo, que passam então a receber uma gratificação salarial e novas atribuições. 
estavam trabalhando em equipes Saúde da Família no interior do Estado e entrevista-los foi uma experiência muito enriquecedora para mim, pois experimentei construir um diálogo com essas pessoas, me disponibilizando para ouvir suas histórias de vida, interesses de trabalho e sua visão sobre Atenção Básica e Apoio Institucional. A experiência com as entrevistas me forneceu um amadurecimento profissional. Por diversas vezes, tive que confiar na minha escuta e na minha intuição para discernir entre dois entrevistados aquele que estaria mais preparado para ingressar no Apoio Institucional.

Outro grande aprendizado foi perceber que na contratação de um Apoiador, é fundamental ter clareza do plano de trabalho a ser desenvolvido. Foi com base nesse instrumento que pude identificar dentre os profissionais aqueles que já traziam bagagens que estavam mais alinhadas com o projeto da DAB para o ano de 20122013. Dessa forma, muitas das escolhas de trabalhadores se mostraram bem sucedidas, porque em curto espaço de tempo os novos Apoiadores desenvolviam uma clara implicação com o trabalho e com o conjunto da equipe. Após a contratação, o outro desafio já se anunciava: acolher esses trabalhadores no novo espaço de trabalho.

Partindo sempre de uma perspectiva de que todos os trabalhadores devam compreender bem sua Instituição e a relação da mesma com outros atores (aqui, leiamse municípios e regionais de saúde), com a equipe ainda parcialmente constituída, as atividades de formação dos novos trabalhadores foram voltadas aos temas fundamentais sobre o Apoio Institucional, a organização interna da DAB e o plano de trabalho da coordenação.

Todos os recém-chegados à DAB participaram de "momentos de acolhimento". A programação era dividida em três dias, turnos matutino e vespertino e contemplava a metodologia ativas de ensino-aprendizagem, detalhada no quadro 1 (anexo). Os momentos iniciais foram importantes para identificar e amadurecer com eles suas novas atribuições. Contudo, além de apresentar o novo espaço de trabalho, procurei resgatar, de cada um, suas experiências profissionais, e ouvir sua visão sobre a nova função, possibilitando, dessa forma, a instituição de vínculo entre estes trabalhadores-coordenação e, o preparo dos mesmos para o ingresso na equipe de trabalho.

\section{Validação de solicitação de passagens e diárias para viabilizar as frequentes viagens dos Apoiadores}

Sendo o trabalho de Apoio Institucional uma atividade que demanda muitas viagens, as necessidades de passagens e diárias para os Apoiadores é muito superior em volume do que em outros setores tanto da FESF-SUS quanto da SESAB. Eram muitas as dificuldades na organização destes pedidos, e os problemas de comunicação entre as instituições envolvidas e a agência intermediadora nos faziam perder muito tempo de trabalho, pois era tanta confusão que muitos dos pedidos não eram processados e, não raro, algumas agendas externas sofreram com atrasos ou desmarcações.

Sentia-me extremamente responsável por fazer com que cada pedido fosse encaminhado corretamente. Por isso, tornei esta atividade uma prioridade diária e, não raras as vezes, só terminava um dia de trabalho após me certificar de que os Apoiadores estavam com as passagens compradas e seus destinos e horários confirmados. Descobri que minhas habilidades com informática poderiam ser úteis nesse momento pois, numa diretoria do porte da $D A B$, era necessário que mais tecnologia fosse incorporada para agilizar nosso fazer cotidiano. Para isso, desenvolveu-se o 
"Sistema de Solicitação de Passagens e Diárias" a partir da ferramenta de construção de formulários on line do Google Drive $^{8}$.

\section{Construção de um plano de trabalho}

Quando cheguei à coordenação, uma das demandas das equipes era que houvesse mais direcionalidade na organização do processo de trabalho. À vista disso, para possibilitar o entendimento de todos (inclusive 0 meu) acerca do processo trabalho, das ações a serem desenvolvidas e das prioridades para o ano de 2012, a coordenação elaborou e propôs ao grupo um plano de trabalho para o Apoio Institucional. Era a primeira vez que iniciaríamos o ano com clareza de onde gostaríamos de chegar e quais eram as nossas principais metas baseadas no Contrato de Programa e no Plano Estadual de Saúde.

O "Plano de Trabalho" era amplo e incluía todas as metas que alcançaríamos juntos. A proposta era que cada equipe de Apoio, a partir do plano apresentado e na avaliação do ano anterior, fizesse seu próprio planejamento de acordo com as especificidades de cada território apoiado e contexto da equipe, adaptando o plano geral segundo sua 7 Por meio desse sistema é possível acompanhar: data e hora de realização do pedido; nome do solicitante, cargo e função; destinos (isto é, município no qual será realizada atividade); descrição das atividades externas a serem realizadas e, tipos de deslocamento. O sistema on line ainda permite a geração de relatórios e o acompanhamento sistemático das atividades externas de apoio institucional realizadas por mês e por apoiador/equipe.

8 O Google Drive é um pacote de aplicativos do Google. Funciona totalmente on-line diretamente no navegador. Os aplicativos são compativeis com o OpenOffice.org/BrOffice.org, KOffice e Microsoft Office, e atualmente compõe-se de um processador de texto, um editor de apresentações, um editor de planilhas e um editor de formulários. Ele permite aos usuários criar e editar documentos online ao mesmo tempo colaborando em tempo real com outros usuários. (WIKIPEDIA, 2013) realidade e criatividade. Num primeiro momento, houve bastante estranhamento da equipe com aquele novo instrumento de trabalho e com as metas estabelecidas. Foi preciso dialogar sobre isso de forma franca e aberta para que não houvesse ruídos de interpretação sobre a proposta de trabalho. Após sentir-se esclarecido, o grupo de Apoiadores assumiu a tarefa, e após, aproximadamente 30 dias, começaram a apresentar os primeiros planos de trabalho macrorregional.

A construção dessa ferramenta foi extremamente útil para mim. Era uma forma de ter mais claro o entendimento do percurso que traçaríamos naquele ano e que metas e atividades deveriam ser acompanhadas. A partir disso, foi possível começar a amadurecer uma proposta de avaliação de desempenho de Apoiadores e equipes na perspectiva de Educação Permanente que viria a ser colocada em prática no final do primeiro ano.

Entretanto, apesar de tantas realizações, eu ainda não estava satisfeita. Olhava para os primeiros cinco meses de atividade na coordenação e percebia o quanto fora capturada pelas demandas estruturadas. Uma certa angústia me envolvia, pois a maior demanda que eu identificava se relacionava com o planejamento, o monitoramento, a avaliação de desempenho e a Educação Permanente da equipe. E destes, somente o planejamento fora executado. Minha exacerbada autocobrança me cegava para o quanto já havia sido conquistado e me fazia colocar cada vez mais o trabalho em primeiro plano deixando de lado minha vida pessoal e o autocuidado. Ao finalizar os primeiros cinco meses, encontrava-me extremamente sobrecarregada. Apesar de estar num contexto de cogestão, eu me dedicava quase que integralmente a minha nova função porque acreditava ser da minha responsabilidade manter o setor em pleno funcionamento, os Apoiadores acolhidos com escuta 
garantida e propor resolução para todos os problemas apresentados.

\section{Fim Do Primeiro Ano}

Como forma de evitar a captura excessiva pelos fluxos e demandas estruturados e avançar em direção aos processos avaliativos e Educação Permanente da equipe percebi que trabalhar sem cessar quase me custou a saúde. Felizmente, percebi a tempo o caminho de adoecimento físico e psíquico que estava prestes a percorrer e decidi redimensionar o trabalho na minha existência. No fim do primeiro ano, melhor dizendo entre os meses de setembro de 2012 a janeiro de 2013, mais disciplinada, fiquei atenta à captura excessiva da minha agenda pelos fluxos e demandas mais estruturados.

A equipe crescia e, nesse período, passou de 20 Apoiadores (sendo oito servidores efetivos da SESAB e 13 empregados contratados pela FESF-SUS ou FAPEX) para 38 Apoiadores (sendo 17 servidores efetivos da SESAB, 13 empregados concursados pela FESF-SUS e seis empregados contratados pela FESF-SUS). O incremento de $65 \%$ na força de trabalho na instituição e levou ao redimensionamento do acolhimento a novos trabalhadores. Nos primeiros cinco meses a defasagem de número de Apoiadores por equipe era muito grande e todo o recém-chegado passava por três dias intensivos de acolhimento e já era direcionado para completar as equipes desfalcadas. Este movimento tinha que ser rápido e objetivo, pois as agendas no território já tinham sido disparadas, e, a preocupação era dar suporte aos Apoiadores que estavam em campo. Dessa forma, estabelecia-se um processo de mão dupla; ao mesmo tempo que um Apoiador mais experiente recebia reforço com a presença do novo colega, o recémchegado era pedagogicamente acolhido, apresentado mais concretamente às ferramentas de trabalho e iniciado na "função" Apoio em ato a partir de atividades no território.

Entretanto, após aliviar essa demanda inicial, tornouse um pouco mais complexo incluir um novo trabalhador em uma equipe de forma que o tempo entre sua chegada e sua inclusão numa equipe levava em torno de 30 a 60 dias; isso porque para fazer a distribuição de trabalhadores no setor era preciso uma análise mais estratégica. Nesse sentido, foram levados em consideração muitos aspectos como: características da região, projetos estratégicos no território, composição e características da equipe e o perfil (habilidades e bagagens) do novo trabalhador. Este tempo, apesar de longo, possibilitou que muitos Apoiadores vivenciassem o espaço de trabalho sem necessariamente ter que se responsabilizar por um território com urgência. Essa mudança metodológica no acolhimento, deixou-os mais à vontade para conhecer os fluxos internos, interagir com toda a equipe da COAD, assim como permitiu que a coordenação os conhecesse melhor no contexto do trabalho na Instituição.

No entanto, "nem tudo são flores". Com a ampliação da equipe, comecei a vivenciar o surgimento de problemas interpessoais no contexto de trabalho. Foi preciso mais uma vez confiar na minha intuição nesse período até que pudesse ter mais clareza quanto a: situações que de fato incomodavam, problemas relacionais existentes e como poderia intervir de forma a apoiar as equipes na resolução dos problemas internos. Não foi muito fácil vivenciar esse processo pois exigia bastante capacidade de escuta e análise para evitar decisões ou intervenções precipitadas. Dei-me conta que eu também estava me formando em ato. Eu, 
que não tinha nenhuma formação em gestão de pessoas, também estava me aprimorando e fui aprendendo a fazer isso junto com a equipe. Foi preciso estar à vontade com o meu "não saber" para poder construir junto aos colegas os caminhos possíveis para enfrentar os problemas cotidianos.

Este período se tornou propício para experimentar uma nova tecnologia: a avaliação do processo de trabalho de equipes de Apoio Institucional e Apoiadores ${ }^{9}$. Nesse sentido, aprimorou-se um instrumento denominado perfil radial de avaliação (ABENO; OPAS; BRASIL. Ministério da Saúde, 2007) como tecnologia para qualificação do processo de trabalho de Apoiadores e equipes de Apoio Institucional da DAB. Entretanto, para apresentar detalhadamente esta ferramenta, seria preciso um capítulo inteiro. Diante disso, eis o porquê dessa ação ser comentada em linhas gerais. O mês de janeiro foi escolhido para priorizar esta atividade pois era um mês de poucas atividades externas. Metodologicamente, era marcado um dia de encontro (carga horária de oito horas) com cada uma das equipes de Apoio. Com os trabalhadores reunidos, distribuía-se um gráfico para que cada um individualmente pudesse se auto avaliar, avaliar os colegas e avaliar a equipe ${ }^{10}$. Após esse momento individual, a coordenação consolidava as avaliações individuais, apresentava o resultado ao grupo e iniciava o momento coletivo de diálogo.

$\mathrm{O}$ instrumento utilizado possibilitou fazer um retrato do momento atual dos trabalhadores, suas principais dificuldades (necessidades de apoio pela equipe e/ou coordenação) e suas principais habilidades, permitindo que

${ }_{9} \mathrm{Na} \mathrm{COAD}$, em anos anteriores, fora ensaiado um movimento no sentido da avaliação de desempenho porém, ainda não se tinha priorizado a agenda do grupo com essa finalidade.

10 Para possibilitar a autoavaliação, a avaliação do colega e da equipe era apresentado ao grupo os padrões de avaliação (pactuados coletivamente) e a escala que variava do abaixo do esperado ao acima do esperado. pudessem ser avaliados no contexto presente com base em suas experiências prévias e em um referencial de futuro baseado nas atribuições esperadas para o cumprimento da "função" Apoio, no âmbito estadual.

Naturalmente, como todo processo avaliativo, foi necessário fazer mediação de conflitos, e este foi mais um dos aprendizados que incorporei à minha prática. As equipes apresentavam pontos de tensão dos mais diversos como por exemplo: descumprimento de carga horária, posturas individualistas em detrimento do coletivo, dificuldades coletivas de organização do trabalho e das demandas, entre outros. Esses pontos de tensionamento foram trazidos para a cena no momento da avaliação, de forma que foi possível trabalhar com o grupo os aspectos objetivos e subjetivos de cada problema apontado. A todo momento, busquei evitar uma avaliação burocrática na qual o objetivo central fosse simplesmente verificar se o trabalhador estaria apto ou não ao trabalho. Ao invés disso, o que se almejava em todo o processo, era possibilitar um espaço dialógico e de pactuação de compromissos, sempre na perspectiva da Educação Permanente.

A priorização desta ação junto às equipes, superou minhas expectativas, porque permitiu o reconhecimento de possíveis mudanças de atitude por parte dos Apoiadores, a organização de processo de trabalho das equipes, resultando no aumento da implicação do Apoiador e sua equipe no desenvolvimento da estratégia de Apoio no âmbito da gestão estadual. Durante o processo avaliativo foi possível diluir e resolver os problemas internos de cada equipe de apoio. Dessa forma, os trabalhadores chegaram mais abertos e renovados para iniciar um novo ano em que faríamos debates densos e provocadores sobre a produção do cuidado e ampliação do acesso à Atenção Básica. 


\section{Os Últimos Nove Meses}

Foi então que, nos últimos nove meses, senti-me coordenadora de fato.

Após o período de avaliação das equipes, estava preparado o terreno para o período que pude vivenciar outro grande desafio: planejar e executar com a equipe a ação estratégica que foi o "carro chefe" da DAB no ano de 2013: o Ciclo de Oficinas de Qualificação da Atenção Básica - ênfase na implantação do Acolhimento. A discussão sobre Acolhimento foi definida como prioridade no planejamento da DAB para o ano de 2013, pois fazia convergir diversas pautas correntes na Atenção Básica, dentre elas destacamse o PMAQ-AB e a implantação das Redes de Atenção em Saúde. Portanto, estimular os municípios quanto às melhores formas de organização do acesso do usuário ao serviço de saúde era o objetivo dessa proposta. ${ }^{11}$

Entretanto, apenas alguns trabalhadores da diretoria tinham alguma experiência prévia com Acolhimento (seja na gestão, seja na assistência), o que potencialmente anunciava a necessidade de preparação intensa para alinhamento e qualificação de toda a equipe em torno de um projeto comum. Diante disso, na segunda quinzena de janeiro de 2013, propôs-se a realização de uma semana de Educação Permanente com a temática "Apoio à Implantação de Acolhimento", conforme programação descrita no quadro 2 (anexo).

É lógico que eu estava insegura em facilitar ${ }^{12}$ esse momento de Educação Permanente! Como seria mediar

\footnotetext{
${ }^{11}$ Para saber mais sobre o Ciclo de Oficinas de Qualificação da Atenção Básica $\neg$ ênfase na Implantação do Acolhimento, acesse o link http:// www.saude.ba.gov.br/dab/index.php?option=com_content\&view=arti cle\&id $=645 \&$ catid $=14 \&$ Itemid $=54$

${ }^{12}$ Além de mim, participaram da elaboração e facilitação desse processo Alessandra Martins dos Reis e José Cristiano Soster.
}

esse debate num grupo tão grande e tão diverso?! O resultado esperado para esse encontro seria alcançado? Como eu poderia ajudar o grupo a compreender, dialogar e pactuar sobre essa ação estratégica? Seria possível após essa semana ter um método de oficina que desse suporte à discussão sobre implantação de Acolhimento?

A atividade foi realizada no ambiente de trabalho dos Apoiadores conforme a programação descrita no quadro 2 (anexo) e todos se envolveram bastante. Como eu precisava de um "termômetro" para perceber a visão dos Apoiadores sobre o processo vivenciado, passei uma cestinha com papel e caneta para que todos pudessem anonimamente depositar sua avaliação da semana.

Segundo avaliação dos próprios participantes, a semana foi considerada um pouco cansativa porém um momento de estudo muito rico e construtivo, onde todos puderam se conhecer melhor, trocar experiências e aprofundar a compreensão de conceitos relacionados à ampliação do acesso e produção do cuidado na Atenção Básica. Muitos consideraram que esta atividade, de fato, instituiu um momento de Educação Permanente na DAB, sendo uma semana prática, objetiva e com imenso valor de uso para o grupo. A proposta provocou os Apoiadores de forma que todos entraram num processo intenso de reflexões, ressignificação do saber e produção coletiva em que descobriram e despertaram para ferramentas e estratégias possíveis de sensibilização, convencimento e colaboração junto às gestões para implantação do Acolhimento. Além disso, essa atividade Ihes deu maior segurança para discussão no território e intervenção local, proporcionando a integração entre teoria e prática, e exploração de diferentes pontos de vista e modos de fazer o Apoio na DAB.

Finalizando a semana de Educação Permanente, 
o resultado esperado tinha sido alcançado: formular a proposta metodológica do Ciclo de Oficinas de Qualificação da Atenção Básica que seria posteriormente pactuado junto às DIRES e municípios. Outro resultado que me animou bastante foi a pactuação de um calendário de atividades mensais de Educação Permanente que contemplou os seguintes temas: apoio para Implantação do Acolhimento; uso do fluxograma descritor para avaliação de processo de trabalho; método de avaliação da implantação do Acolhimento; elaboração de estratégias para adesão qualificada dos municípios à proposta do ciclo de oficinas; saúde bucal no Acolhimento; manejo de grupos; redes de atenção à saúde; planejamento para implantação do Acolhimento em âmbito municipal; construção de matriz de intervenção e utilização do conceito do triângulo de Matus (FUNDACIÓN ALTADIR, 2006) pra análise de viabilidade de projetos.

Isto é, à medida que a ação estratégica foi se desenvolvendo, foi-se também trabalhando na qualificação da equipe, uma vez que partia-se das questões vivenciadas no cotidiano para proporcionar a qualificação do grupo. Dessa forma, houve a consolidação e alinhamento da equipe acerca do tema Acolhimento e estratégias para ativação de coletivos com a finalidade de qualificar a produção do cuidado na Atenção Básica. Entre a segunda quinzena de janeiro a junho de 2013, foram realizados quatro dos cinco encontros presenciais nos territórios, quatro das seis videoconferências temáticas previstas e oito momentos de Educação Permanente com a equipe de Apoiadores da DAB.

Ouso dizer que pensar a Educação Permanente de uma equipe é um dos trabalhos mais difíceis para quem está na coordenação. Não se pode simplesmente impor um tema e uma metodologia, e forçar o grupo a debater; é preciso construir cada momento sabendo que pode ser preciso flexibilizar a programação, metodologia e temas para atender às necessidades dos trabalhadores abrindo espaço, inclusive, para a vazão de incômodos e questionamentos.

Esta foi uma das atividades mais prazerosas que vivenciei no ano de 2013; foi quando tive a certeza de que estava no lugar certo, portanto coordenadora de fato. Foi preciso muita escuta do que as equipes traziam do território, suas demandas e principais dificuldades e, a partir daí, pedagogicamente, propor os temas de Educação Permanente que teriam maior valor de uso para o grupo. Muitas vezes, tive que: facilitar o espaço; mediar discussões; aquecer o grupo com provocações e; sair de cena reconhecendo minhas limitações e abrindo espaço para que o próprio grupo propusesse e facilitasse essas atividades. Aos poucos fui perdendo o receio da exposição que esse tipo de atividade traz e me senti mais à vontade para estar com os trabalhadores num espaço pedagógico e dialógico, onde todos, inclusive eu, estávamos ensinando e aprendendo.

\section{Considerações Finais}

Coordenar equipes é um ato complexo que exige: escuta qualificada dos problemas e necessidades dos trabalhadores; cartografia da realidade de cada equipe e território apoiado identificando as especificidades de cada um; atenção à manutenção da infraestrutura e dos recursos necessários para o desenvolvimento do trabalho; construção de planejamento com metas claras e objetivas; pactuação de plano de trabalho de forma dialógica; acompanhamento sistemático e periódico das equipes com promoção de debates sobre seu processo de trabalho; 
organização de forma regular de momentos de Educação Permanente, entre outros (BAHIA, 2013).

Nesta caminhada de 18 meses, muitas vezes deixei capturar-me pelas tarefas estruturadas pois elas me traziam mais segurança em meio a um campo tão desconhecido para mim. Contudo, as tarefas estruturadas aprisionavamme causando uma profunda sensação de afastamento da equipe e de suas necessidades. No decorrer da jornada, aprimorei a habilidade de fazer a escuta qualificada o que me fez reafirmar que essa não pode ser encarada como uma atividade trabalhosa e atribuída a um profissional sensível, portador de "certa essência" (BARROS; BOTAZZO, 2011). Todo coordenador que deseje se aproximar de sua equipe deve ouvir com atenção o trabalhador; dedicar tempo para que ele expresse angústias, problemas e, alegrias; acolher sua demanda e orientá-lo.

Além da escuta, tive que recorrer à intuição diversas vezes, para ter discernimento e evitar precipitações principalmente na mediação de conflitos intra ou interequipes. De fato, quando se está na função de coordenação existe uma certa expectativa dos trabalhadores em apresentar problemas e receber soluções prontas, imediatas. É como se o coordenador pudesse tirar da cartola a receita mágica para acabar com as tensões muitas vezes criadas no âmbito da própria equipe devido a dificuldades de comunicação. Compreendi que para atender às demandas institucionais e às exigências da função Apoio, não raro, é tarefa de o coordenador acompanhar o desenvolvimento do plano de trabalho do conjunto de trabalhadores, valorizar a atuação dos mesmos, identificar talentos em sua equipe e corrigir trajetórias no intuito de constituir um setor em que seus trabalhadores e sua força de trabalho estejam bem distribuídos, saudáveis, capacitados e motivados (BRASIL, 2007).
Aprendi que para ser coordenador não é preciso concentrar todo o conhecimento especializado de um determinado setor. Mais do que conhecimento, é fundamental colocar-se em processo de formação cotidiana junto com a equipe, e construindo uma relação de confiança, verdade e mútua cooperação. Olhar retrospectivamente para minha experiência de trabalho me faz perceber as semelhanças existentes entre a função que assumi na coordenação da COAD e a Coordenação Municipal de Atenção Básica. E isso me fez ficar mais solidária à realidade dos colegas e ter mais clareza de como apoiá-los por meio do Apoio Institucional.

\section{Referências}

ABENO; OPAS; BRASIL. Ministério da Saúde.Implantação das diretrizes curriculares nacionais em odontologia. 2007. Disponível em http://abeno.org.br/arquivos/downloads/ download_20111109153352.pdf. Acesso em: maio 2013.

BAHIA. Comissão Intergestores Bipartite da Bahia. Resolução CIB no. 132 de 20 de setembro 2007. Aprova o novo desenho do Plano Diretor de Regionalização do Estado da Bahia. Disponível em: < http://www2.saude.ba.gov. br/cib/arquivos /Resolu\%C3\%A7\%C3\%B5es\% 20da\%20 ClB/2007/Resolu\%C3\%A7\%C3\%B5es\%202007.pdf>. Acesso em: 17 maio 2014.

BAHIA. Secretaria de Saúde. Diretoria de Atenção Básica. Dos Princípios, Eixos Estruturantes e Frentes de Ação da Política Estadual de Atenção Básica. In:

Estadual de Atenção Básica. 2013. 41 p.

Política

BARROS, R. S; BOTAZZO, C. Subjetividade e clínica na 
Atenção Básica narrativas, histórias de vida e realidade social. Ciência e saúde coletiva, v. 16, n. 11, p. 43374348, 2011. Disponível em: http://www.scielo.br/pdf/csc/ v16n11/a06v16n11.pdf. Acesso em: 20 nov 2013.

BERTUSSI, D. C. $O$ apoio matricial rizomático e a produção de coletivos na gestão municipal em saúde. Rio de Janeiro: UFRJ / Faculdade de Medicina, 2010. Disponível em: http:// www.ims.uerj.br/ccaps/wp-content/uploads/2012/07/ Bertussi_Tese.pdf

BRASIL. Conselho Nacional de Secretários de Saúde. Gestão do Trabalho na Saúde / Conselho Nacional de Secretários de Saúde. Brasília : CONASS, 2007.

CAMPOS, G. W. S. Saúde Paidéia. São Paulo. Hucitec, 2007. $185 \mathrm{p}$.

WIKIPEDIA. Google Docs. Disponível em: http://pt.wikipedia. org/wiki/Google_Docs. Acesso em: 16 nov 2013.

MERHY, E. E. Saúde - a cartografia do trabalho vivo. 2.ed. São Paulo. Hucitec, 2005. 189 p.

\section{Anexo}

Quadro 1 - Metodologia para acolhimento de novos trabalhadores

\begin{tabular}{|c|c|}
\hline \multicolumn{2}{|r|}{ 10 dia - Recepção e Aproximação } \\
\hline Manhã & $\begin{array}{l}\text { Participação na reunião da COAD e equipes de } \\
\text { Apoio Institucional } \\
\text { Objetivo - recepcionar os novos Apoiadores em } \\
\text { reunião da COAD pelos novos colegas, participam } \\
\text { da reunião, debates e percepção do ambiente de } \\
\text { trabalho no Apoio Institucional }\end{array}$ \\
\hline Tarde & $\begin{array}{l}\text { Reunião com a coordenação COAD/DAB } \\
\text { e Contratualização e Apoio Institucional (COCAI- } \\
\text { FESF/SUS) / apresentação do Apoiador aos demais } \\
\text { componentes da equipe } \\
\text { Objetivo - reconhecer a percepção dos novos } \\
\text { Apoiadores sobre o momento da manhã, suas } \\
\text { expectativas com a coordenação }\end{array}$ \\
\hline \multicolumn{2}{|c|}{$\begin{array}{l}\text { 20 dia - Primeiros Contatos com ferramentas, fluxos e } \\
\text { agendas }\end{array}$} \\
\hline Manhã & $\begin{array}{l}\text { Aproximação junto à nova equipe } \\
\text { Objetivo - Aproximar o novo Apoiador das } \\
\text { ferramentas, agendas e fluxos das equipes. }\end{array}$ \\
\hline
\end{tabular}




\begin{tabular}{|c|c|}
\hline Tarde & $\begin{array}{l}\text { Reunião com a coordenação da COAD } \\
\text { Objetivo - Avaliar os primeiros momentos na DAB, } \\
\text { apresentar o organograma da DAB, do trabalho e do } \\
\text { papel como Apoiador Institucional / apresentação } \\
\text { de fluxos, instrumentos e agendas. }\end{array}$ \\
\hline \multicolumn{2}{|r|}{ 30 dia - Pactos de Funcionamento da DAB } \\
\hline Manhã & $\begin{array}{l}\text { Apresentação dos pactos de funcionamento da } \\
\text { DAB } \\
\text { Objetivo - Apresentar o funcionamento e os pactos } \\
\text { de trabalho na DAB }\end{array}$ \\
\hline Tarde & $\begin{array}{l}\text { Aproximação junto à nova equipe } \\
\text { Objetivo - Aproximar o novo Apoiador das } \\
\text { ferramentas, agendas e fluxos das equipes }\end{array}$ \\
\hline \multicolumn{2}{|c|}{$\begin{array}{l}\text { Quadro } 4 \text { - Metodologia para Educação Permanente com } \\
\text { ênfase no tema "Apoio à Implantação do Acolhimento" }\end{array}$} \\
\hline \multicolumn{2}{|r|}{ 10 DIA } \\
\hline Manhã & $\begin{array}{l}\text { Apresentação da programação da semana } \\
\text { Apresentação do objetivo da oficina } \\
\text { Tarefa: divididos em } 09 \text { equipes de Apoio, construir } \\
\text { um caso real e extremo de um usuário que busca } \\
\text { atendimento. Considerando na descrição: o caso } \\
\text { clínico, a realidade da equipe Saúde da Família } \\
\text { (composição da equipe, processo de trabalho } \\
\text { (agenda, recepção, horário de funcionamento, } \\
\text { principais demandas de atendimento), estrutura } \\
\text { disponível, rede de saúde do município). Relatar } \\
\text { o caso até seu desfecho resgatando o caminho } \\
\text { percorrido pelo usuário na rede. Para construção } \\
\text { do caso, a equipe poderia entrar em contato com a } \\
\text { Dires e/ou com o município. }\end{array}$ \\
\hline
\end{tabular}

Reunir todas as equipes de Apoio e sortear os casos elaborados entre as equipes.

Tarefa: com base no caso a equipe deverá construir proposta de implantação de Acolhimento.

Questão norteadora:

a) O que precisa ser mudado naquela realidade considerando o contexto da equipe, fluxos da rede, processo de trabalho, relação com controle social, gestão do cuidado?

Tarde b) Qual a diretriz de Acolhimento a ser implantada com a equipe considerando também a saúde bucal?

c) Qual caminho/ metodologia deve ser proposta para implantação de Acolhimento junto à ESF?

d) Qual o cronograma de atividades para implantação do Acolhimento?

e) Quais os indicadores para acompanhamento da implantação do Acolhimento?

\section{DIA}

Continuidade da tarefa iniciada no dia anterior.

Tarefa: Sistematização da discussão e apresentação do plano de ação (apresentar situação problema trabalhada), sendo que o "Plano de Ação" deveria apontar para a necessidade de pactuação com os outros pontos da rede. Para construção do plano de ação, as equipes de apoio utilizaram a matriz de intervenção do PMAQ. 


\begin{tabular}{l|l}
\hline \multicolumn{1}{c}{ 30 DIA } \\
\hline $\begin{array}{l}\text { Manhã } \\
\text { e Tarde }\end{array}$ & $\begin{array}{l}\text { Tarefa: Apresentação do plano de ação } \\
\text { contextualizado baseado na matriz de intervenção } \\
\text { do PMAQ. } \\
\text { Cada equipe teve } 30 \text { minutos para apresentar e } 10 \\
\text { minutos de debate. }\end{array}$ \\
\hline Manhã & $\begin{array}{l}\text { 40 DIA } \\
\text { Atenção Básica com presença de consultor externo. }\end{array}$ \\
\hline Tarde & $\begin{array}{l}\text { Apresentação da proposta metodológica das } \\
\text { oficinas para qualificação da AB e qualificação da } \\
\text { mesma com equipe de Apoiadores. }\end{array}$ \\
\hline
\end{tabular}

\section{Quem somos nós: organizadora, colaboradoras, revisora e autores.}

\section{ORGANIZADORA}

Letícia de Moraes Falleiro é fisioterapeuta graduada pela UDESC/SC, pós-graduada pela Residência Multiprofissional em Saúde Coletiva com ênfase em Atenção Básica da EEESPRS, mestranda em Saúde Coletiva pela UEFS/BA. Atua como Apoiadora Institucional na COAD/DAB/SAIS/SESAB pelo contrato de programa entre FESF-SUS e SESAB. Contato: leticiamfalleiro@gmail.com

\section{COLABORADORAS}

Rebeca Silva de Barros é cirurgiã-dentista graduada pela Faculdade de Odontologia da Universidade de São Paulo, especialista em Saúde Coletiva pelo Instituto de Saúde da Secretaria Estadual de Saúde de São Paulo. Mestranda em Saúde Coletiva pela UEFS/BA. Exerce a função de Coordenação da COAD/DAB/SAIS/SESAB pelo contrato de programa entre FESF-SUS eSESAB. Contato: rebecasbarros@ gmail.com

Samantha de Jesus Andrade é enfermeira pela Universidade Federal da Bahia. Pós Graduação em Gestão em Saúde pela Fundação Bahiana de Medicina. Atua como Apoiadora 
Institucional na COAD/DAB/SAIS/SESAB pelo contrato de programa entre FESF-SUS e SESAB. Contato: sjaenf@yahoo. com.br

Vanessa Carol de Souza Lima é fisioterapeuta pela Universidade Federal da Paraíba, (UFPB), especialista em Política Gestão Cuidado Saúde pela UFPB, especialista em Saúde da Família pela Escola de Formação em Saúde da Família Visconde de Sabóia (EFSFVS). Atua como Assessora Técnica da Coordenação de Planejamento e Dimensionamento na DEPREPS /SGTES / MS. Contato: vcslima@yahoo.com.br

\section{REVISORA}

Raimunda Maria Cerqueira Santos é enfermeira obstétrica, sanitarista, bacharela em Direito, sanitarista do quadro de pessoal efetivo da SESAB.

\section{PREFÁCIO}

Caroline Castanho Duarte é enfermeira pela Universidade Estadual de Londrina (2004). Especialista Saúde Coletiva e Atenção Básica pela Escola de Saúde Pública do Rio Grande do Sul (2007). Especialista em Gestão Pública Estratégica para Governantes pela Universidade Estadual de Campinas (2010). Mestre em Saúde Coletiva pela Universidade Estadual de Feira de Santana.

\section{AUTORES}

Alan Jonh de Jesus Costa é professor de educação física, especialista em Ativação de Processos de Mudança na formação superior de profissionais de saúde pela ENSP/ Fiocruz, e em Metodologia da Pesquisa e do Ensino em Educação Física, Esporte e Lazer pela UFBA. Atua como Apoiador Institucional na COAD/DAB/SAIS/SESAB pelo contrato de programa entre FESF-SUS e SESAB. Contato:alanjonh@hotmail.com

Alessandra Martins dos Reis é enfermeira, especialista em Saúde da Família e mestre em Saúde Coletiva. Atua como Assessora na Superintendência de Atenção Integral à Saúde da Secretaria da Saúde do Estado da Bahia. Contato: alemreis@hotmail.com

Américo Yuiti Mori é enfermeiro, especialista em Saúde da Família e Apoio em Saúde. Atua como técnico do Departamento de Planejamento da Regulação e Provisão dos Profissionais da Saúde, SGTES/MS. Contato: americomori@ gmail.com

Ana Cristina Guimarães é assistente social. Atua como Coordenadora dos Hospitais de Urgência da Região Metropolitana de Salvador na Diretoria de Gestão da Rede Própria da Secretaria da Saúde do Estado da Bahia. Contato: crisguima11@gmail.com

Daisy Matos é cirurgiã-dentista, sanitarista pela Universidade Federal da Bahia (UFBA). Atua como Apoiadora Institucional na COAD/DAB/SAIS/SESAB pela FESF-SUS pelo contrato de programa entre FESF-SUS e SESAB. Contato: macrocentroleste@gmail.com

Françoise Oliveira é farmacêutica, sanitarista pela Residência Multiprofissional em Medicina Social, com ênfase em Saúde da Família pelo Instituto de Saúde Coletiva da Universidade Federal da Bahia (ISC/UFBA). Atua como Apoiadora Institucional na COAD/DAB/SAIS/SESAB pela FESF-SUS pelo contrato de programa entre FESF-SUS e SESAB. Contato: macrocentroleste@gmail.com

João André Santos de Oliveira é médico. Atua como professor do Departamento de Saúde da Família da 
Faculdade de Medicina da Universidade Federal da Bahia. Contato:j.andre2002@gmail.com

Kally Cristina Soares Silva, odontóloga, sanitarista, especialista em Saúde da Família com ênfase em Gestão de processo de trabalho pela UFBA, mestranda do Programa de Mestrado Profissional em Saúde Coletiva pela UEFS. Exerce a função de Coordenação da COAD/DAB/SAIS/ SESAB.Contato: kcssvl@hotmail.com

Karísia Macêdo Batista é enfermeira pela Universidade Estadual de Santa Cruz (UESC), especialista em Saúde Pública pela Universidade Estácio de Sá, especialista em Gestão da Atenção Básica com ênfase na Implantação de Linhas de Cuidado pela Escola Estadual de Saúde Pública. Contato: karisiamacedo@yahoo.com.br.

Leandro Dominguez Barretto é médico. Atua como professor do Departamento de Saúde da Família na Faculdade de Medicina da Universidade Federal da Bahia. Contato: Idb.leandro@gmail.com

Letícia de Moraes Falleiro é fisioterapeuta graduada pela UDESC/SC, pós-graduada pela Residência Multiprofissional em Saúde Coletiva com ênfase em Atenção Básica da EEESPRS, mestranda em Saúde Coletiva pela UEFS/BA. Atua como Apoiadora Institucional na COAD/DAB/SAIS/SESAB pelo contrato de programa entre FESF-SUS e SESAB. Contato: leticiamfalleiro@gmail.com

Nilma Lima dos Santos é fonoaudióloga, sanitarista. Atua como Apoiadora Institucional na COAD/DAB/SAIS/SESAB pelo contrato de programa entre FESF-SUS e SESAB. Contato: nilmasantos28@gmail.com

Rebeca Silva de Barros é cirurgiã-dentista graduada pela Faculdade de Odontologia da Universidade de São Paulo, especialista em saúde coletiva pelo Instituto de Saúde da Secretaria Estadual de Saúde de São Paulo. Mestranda em Saúde Coletiva pela UEFS/BA. Exerce a função de Coordenação da COAD/DAB/SAIS/SESAB pelo contrato de programa entre FESF-SUS eSESAB.Contato: rebecasbarros@ gmail.com

Rosana Fialho é cirurgiã-dentista, sanitarista, especialista em Saúde Pública, Gestão em Saúde e Pneumologia Sanitária e mestranda em Saúde Coletiva pelo Mestrado Profissional da Universidade Estadual de Feira de Santana (UEFS). Atua como Apoiadora Institucional na COAD/DAB/ SAIS/SESAB pelo contrato de programa entre FESF-SUS e SESAB. Contato: macrocentroleste@gmail.com

Sílvia Denise Laranjeira Cardoso é enfermeira sanitarista do quadro efetivo da SESAB, mestre pelo Instituto de Saúde Coletiva da Universidade Federal da Bahia (ISC/UFBA). Atua como Apoiadora Institucional na COAD/DAB/SAIS/SESAB. Contato: macrocentroleste@gmail.com

Vanessa Carol de Souza Lima é fisioterapeuta pela Universidade Federal da Paraíba, (UFPB), especialista em Política Gestão Cuidado Saúde pela UFPB, especialista em Saúde da Família pela Escola de Formação em Saúde da Família Visconde de Sabóia (EFSFVS). Atua como Assessora Técnica da Coordenação de Planejamento e Dimensionamento na DEPREPS /SGTES / MS. Contato: vcslima@yahoo.com.br

Yara Lúcia Pedreira é enfermeira. Atua como supervisora dos Hospitais de Urgência da Região Metropolitana de Salvador na Diretoria de Gestão da Rede Própria da Secretaria da Saúde do Estado da Bahia. Contato: yarapedreira@bol. com.br 


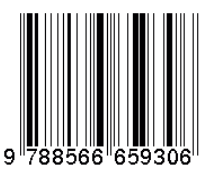

\section{Publicações da Editora Rede UNIDA}

\section{Coleções e Série}

Arte Popular, Cultura e Poesia

Clássicos da Saúde Coletiva

Micropolítica do Trabalho e o Cuidado em Saúde

Cadernos da Saúde Coletiva

\section{Outras publicações}

"Bulindo" com a Universidade - Um estudo sobre o trote na medicina

Girando Vida, Políticas e Existências: reunindo experiências com leveza e movimento - Construção do 11 Congresso Internacional da Rede UNIDA

Evidencias y Narrativas - Una perspectiva antropológica.

editora

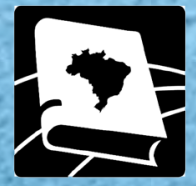

redeunida

www.redeunida.org.br 